\title{
SAÚDE, AMBIENTE E SUSTENTABILIDADE
}

\section{AUTORES}

Lia Giraldo da Silva Augusto

Fernando Ferreira Carneiro

Wanderlei Antonio Pignati

Raquel Maria Rigotto

Karen Friedrich

Neice Muller Xavier Faria

André Campos Búrigo

Vinicius Mello Teixeira de Freitas
Colaboradores

Ada Cristina Pontes Aguiar

Guilherme Costa Delgado

Horácio Martins de Carvalho

Lucas Resende

Marcelo Firpo de Souza Porto

Núcleo Tramas

Pedro Costa Cavalcanti de Albuquerque

Vanira Matos Pessoa

Veruska Prado Alexandre

Vicente Almeida 


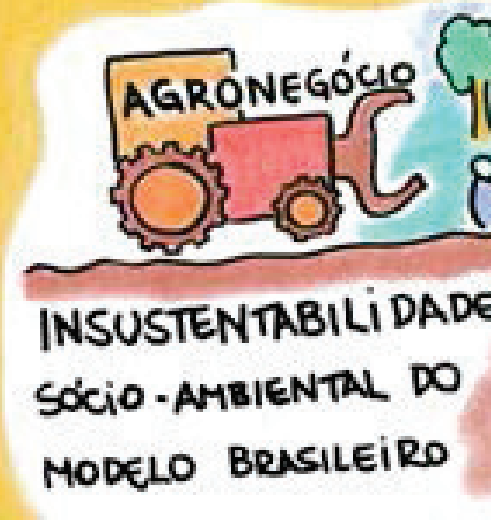

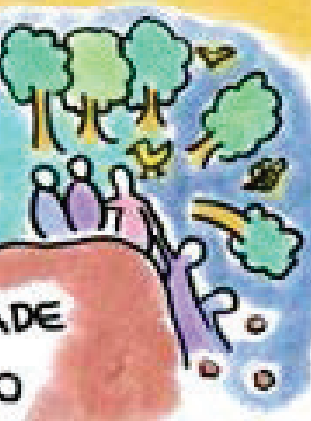

Nomulaḉo Nor

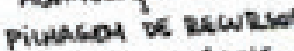
Dos mis reáciseis.

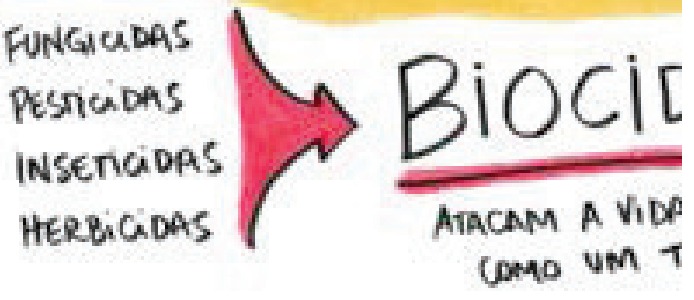

WaAs do Rio VEDEX-MT

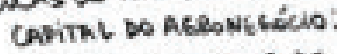
Mutres impactos $k$ venentos AGlícolas

DESGOO cousad Moxua 1) ONTEAS

\section{O QUE ENTENDE}

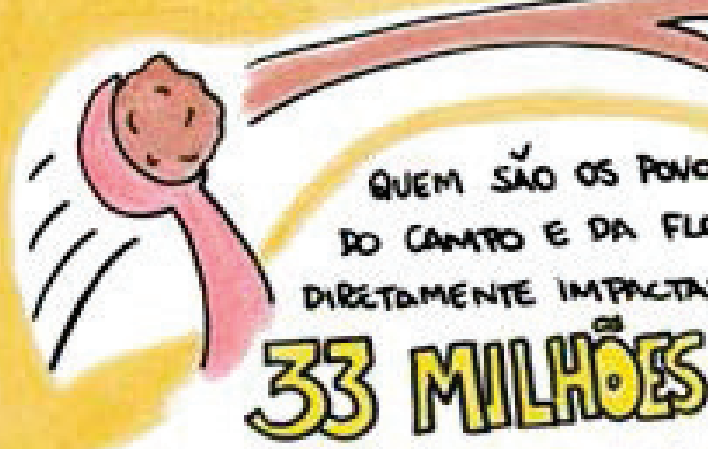

Actados?

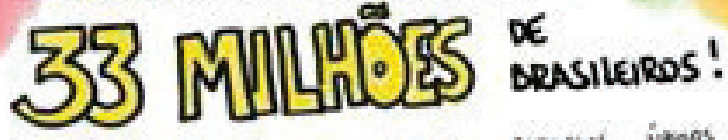

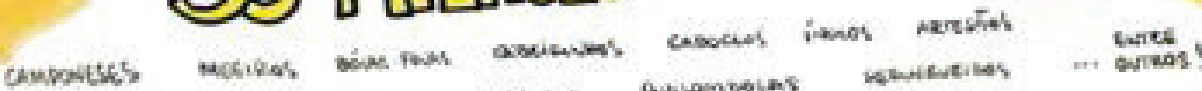

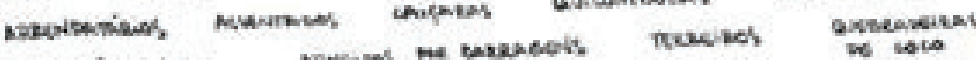

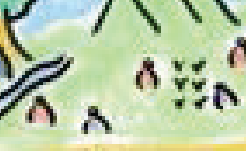

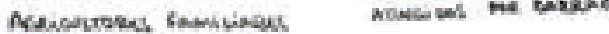

COM VULNERABILIDADES múltTipLAS!

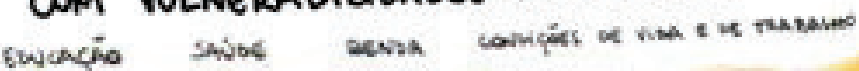

LUTAS

RECONS

TERRIT

SUSTEN

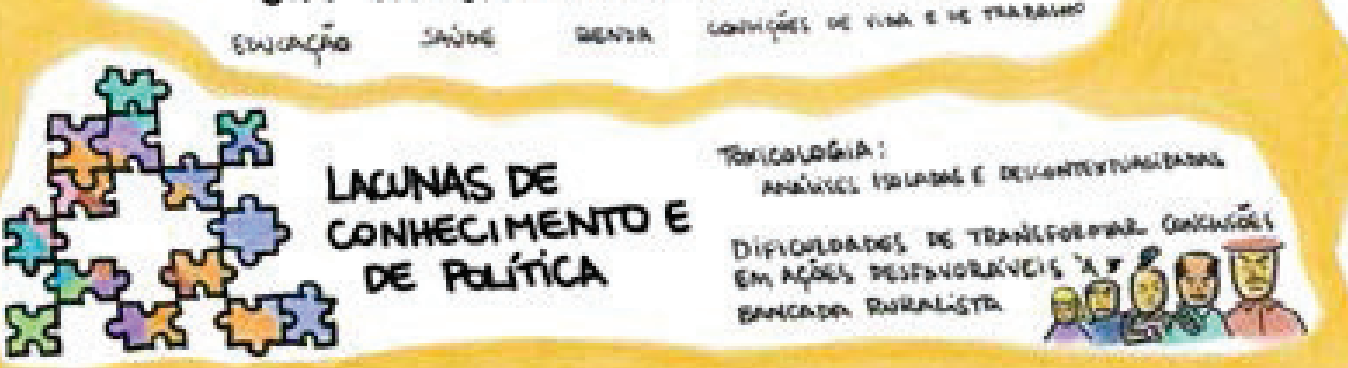

constí snin 0 rea Miokis

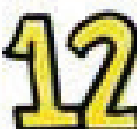




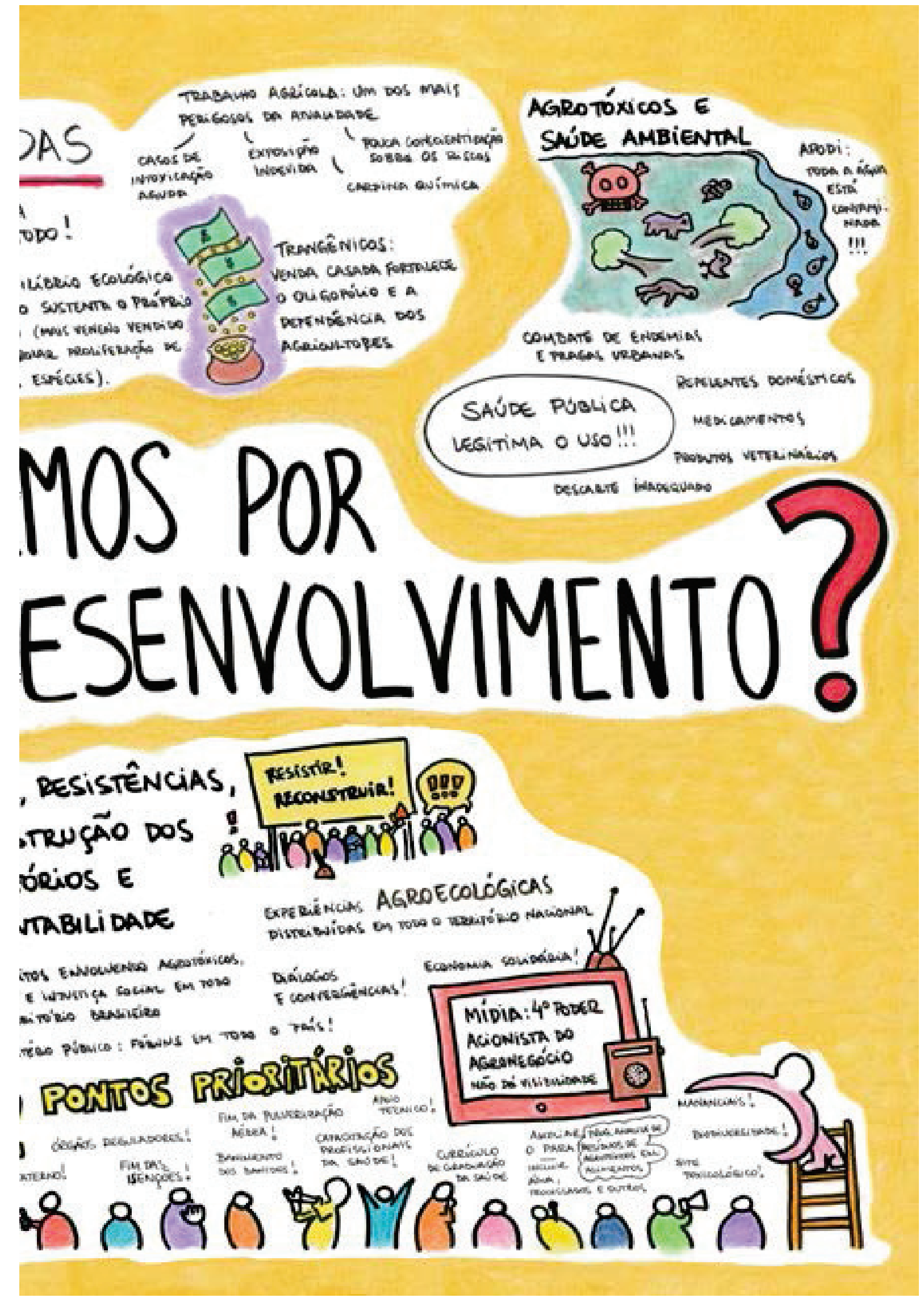




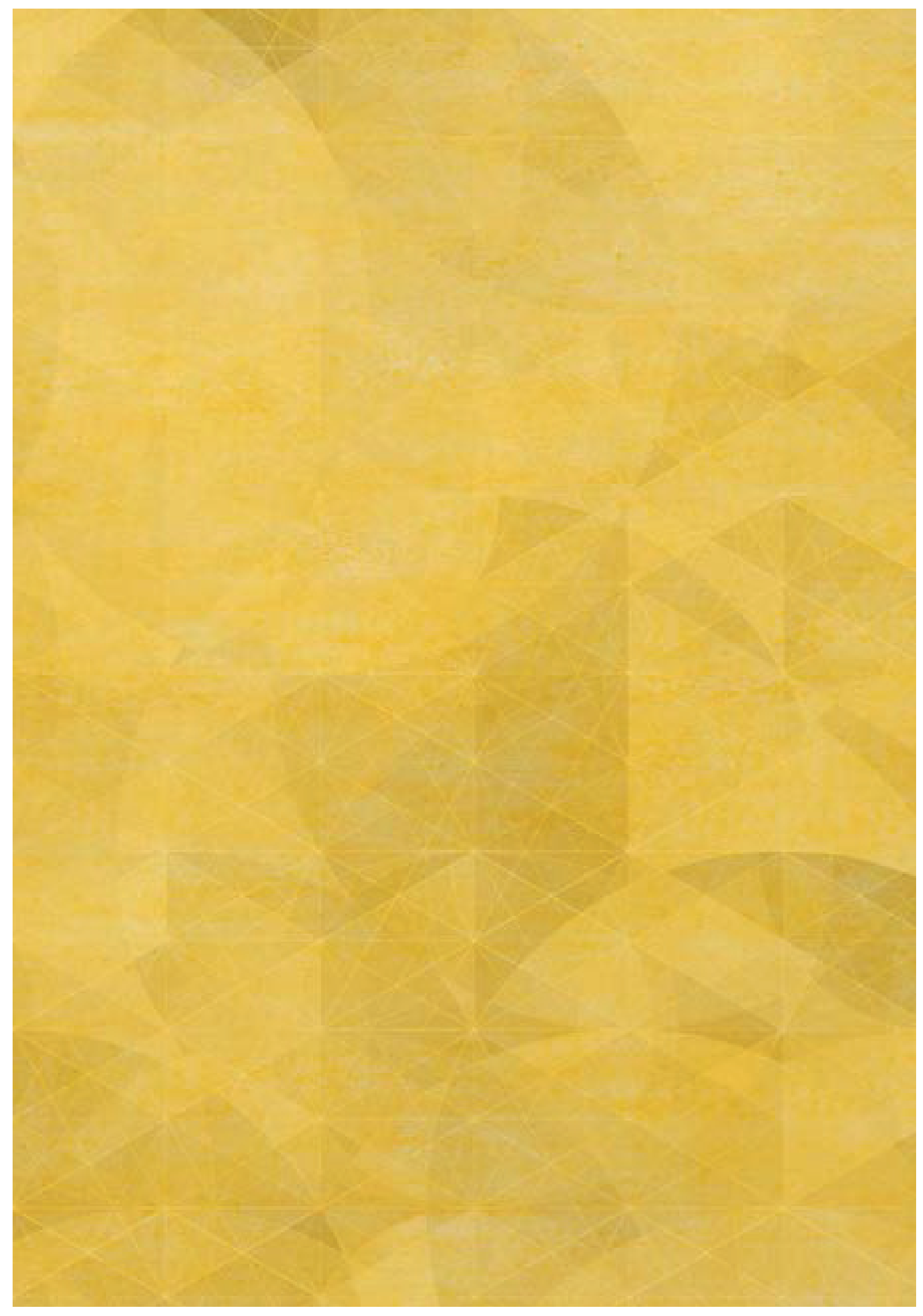




\section{PARTE 2}

SAÚDE, AMBIENTE

E SUSTENTABILIDADE

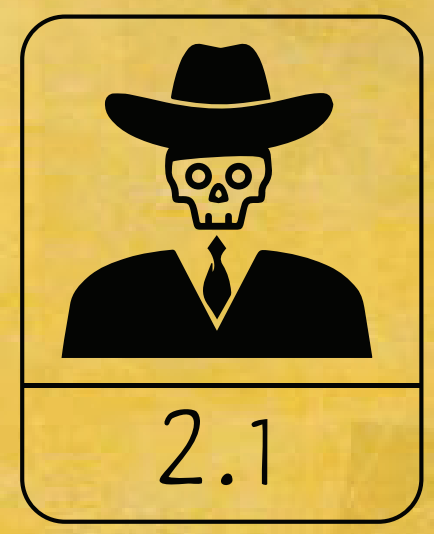

\section{O dossiê no contexto da Rio+20}

No início da década de 1950, apesar de tragédias humanas e ambientais como a que ocorreu no cenário de morte de pescadores e moradores contaminados por efluentes líquidos industriais contendo mercúrio na baía de Minamata, Japão, a proteção contra os impactos químicos do crescimento industrial desenfreado não estava incluída entre as prioridades internacionais.

Há cinquenta anos, quando a questão ambiental ainda não estava reconhecida e nomeada como problema na agenda política internacional, Rachel Carson lançou Primavera Silenciosa.

INSUSTENTABILIDADE SOCIOAMBIENTAL DO AGRONEGÓCIO BRASILEIRO

\section{dossiêABRASCO}

No livro, Carson faz um alerta agudo e profundo, mostrando a complexidade e a delicadeza das inter-relações ecológicas feridas pelos agrotóxicos e levantando fortes indagações sobre os impactos da acelerada expansão dos sistemas sociotécnicos do desenvolvimento capitalista sobre a vida (CARSON, 2010).

Dez anos depois, sob o eco do relatório "Limites do Crescimento", realiza-se em Estocolmo a I Conferência das Nações Unidas sobre Meio Ambiente e Desenvolvimento. A formulação da noção de desenvolvimento sustentável, em resposta à necessidade de acomodar problemas sociais e ambientais com os interesses econômicos hegemônicos, resultou em uma retórica que supõe esquecer que a civilização do capital é estruturalmente avessa a limites à sua permanente expansão e historicamente produtora de desigualdades. 
Essa contradição de interesses ficou explícita no desastre de Bhopal, na Índia, ocorrido em 1984, que produziu cerca de quatro mil mortes diretas e pelo menos duzentos mil casos de efeitos crônicos, além de graves contaminações ambientais. A tragédia, ocorrida a partir de uma das fábricas da multinacional americana Union Carbide (hoje pertencente à Dow Química), foi produzida pelo vazamento de quarenta toneladas de gases tóxicos (isocianato de metila e hidrocianeto) usados no processo de fabricação de agrotóxicos, e até hoje as consequências dessa destruição impactam a vida de milhares de pessoas.

Os escassos avanços nos pactos que esse paradigma orientou na Conferência das Nações Unidas sobre o Meio Ambiente e o Desenvolvimento realizada no Rio de Janeiro em 1992, a Eco 92 - mudanças climáticas, biodiversidade, desertificação e a própria Agenda 21 - podem ser compreendidos no contexto de crise do capital, fortemente expressa em 2008. Destrutividade, pilhagem ambiental, espoliação do trabalho e das populações, neocolonialismo e neodesenvolvimentismo são conceitos-chave para caracterizar este momento da civilização do capital. Trata-se de processos que contam com apoio dos Estados, mediante financiamento do agronegócio e desregulação, e em que a pressão pela apropriação e mercantilização, nos fluxos internacionais da acumulação, de territórios da América Latina, da África e da Ásia leva à violência física e simbólica contra os direitos dos povos que neles vivem, especialmente os grupos étnicos, as comunidades tradicionais, os camponeses, os pobres, as mulheres.

$\mathrm{Na}$ Rio+20, a Conferência das Nações Unidas sobre o Meio Ambiente e o Desenvolvimento realizada no Rio de Janeiro em 2012, um passo a mais é dado, para além da retórica: os grandes grupos econômicos se colocam como atores centrais na resolução da crise ambiental e assumem cinicamente que esses enormes e graves problemas que ameaçam a sobrevivência da espécie humana podem se converter em nichos de mercado, transformando-se em novas fontes de acumulação - o mercado de carbono, comercializando o direito de poluir, é o exemplo mais evidente da ética e dos interesses que orientam a chamada economia verde (LEROY, 2012).

Porto-Gonçalves (2012), ao analisar a "Minuta zero do documento-base de negociação da Rio+20", registra a primazia com que a dimensão econômica aparece, em detrimento de outras categorias consideradas centrais para o debate na atual conjuntura social. Segundo o autor,

a dimensão econômica aparece 55 vezes nas 19 páginas, contra apenas 7 referências ao ambiental e seus derivados, e somente em 3 vezes aparece a explicitação da dimensão cultural, exclusivamente no item 16, ou seja, em somente um item dentre os 128 que compõem o documento aparece a referência à cultura (PORTO-GONÇALVES, 2012, p. 2).

Esse forte indicativo das diretivas que estão sendo formuladas pelos representantes mundiais para o futuro do planeta Terra explicita a contradição em processo do modelo capitalista que transforma a crise civilizacional em nicho de mercado global, como alerta Leroy (2012). 
Em contrapartida, movimentos sociais, organizações não governamentais e demais segmentos da sociedade civil se reúnem em evento paralelo denominado Cúpula dos Povos na Rio+20 por Justiça Social e Ambiental. O título explicita a centralidade do lugar ocupado pela luta por justiça socioambiental nas agendas políticas de grande parcela dos povos, diametralmente oposto ao do atual modelo de produção e consumo capitalistas. Nesse sentido, a Cúpula dos Povos não pretende ser apenas mais um evento em grande escala, mas sim a materialização de um constructo sócio-histórico que reúne nas convergências das resistências locais, regionais e globais a força para engendrar a luta anticapitalista, classista, antirracista, antipatriarcal e anti-homofóbica ${ }^{1}$.

O debate em torno da construção da Cúpula dos Povos parte da avaliação de que na Rio+20 não será realizado um balanço profundo do que aconteceu nos últimos vinte anos (desde a Eco 92), procurando analisar os impactos do desenvolvimento nesse período, e, a partir daí, de forma democrática traçar as estratégias de futuro para a humanidade. Considerando essa avaliação, a Cúpula dos Povos está organizada em torno de três eixos: avaliação das causas estruturais da crise civilizatória, denúncia das falsas soluções apresentadas pelo capital e apresentação das soluções construídas pelos povos dos diferentes territórios do planeta.

No contexto deste dossiê, é fundamental ressaltar que a Rio+20 acontece justamente cinquenta anos após o lançamento do livro Primavera Silenciosa. Para denunciar a poluição ambiental provocada pelo uso indiscriminado de pesticidas nos campos americanos, Carson realizou extensa pesquisa científica. Em seu trabalho, ela soube mostrar ao público, que não estava acostumado aos termos técnicos, como o uso indiscriminado de agrotóxicos (do inglês pesticides), em especial o diclorodifeniltricloroetano (DDT), é prejudicial às plantas, às águas, aos animais e aos seres humanos.

Através de um debate baseado nos princípios ecológicos, explorando a forma como a vida na Terra está conectada a cada elemento, a autora propôs que o termo que mais apropriadamente define os agrotóxicos (ou pesticides) é "biocidas":

há muitas [substâncias químicas] que são usadas na guerra da humanidade contra a natureza. Desde meados da década de 1940 mais de duzentos produtos químicos básicos foram criados para serem usados na matança de insetos, ervas daninhas, roedores e outros organismos descritos no linguajar moderno como 'pestes', e eles são vendidos sob milhares de nomes de marcas diferentes. Esses sprays, pós e aerossóis são agora aplicados quase universalmente em fazendas, jardins, florestas e residências - produtos químicos não seletivos, com o poder de matar todos os insetos, os 'bons' e os 'maus', de silenciar o canto dos pássaros e deter o pulo dos peixes nos rios, de cobrir as folhas com uma película letal e de permanecer no solo - tudo isso mesmo que o alvo em mira possa ser

\footnotetext{
${ }^{1}$ www.cupuladospovos.org.br
} 
apenas umas poucas ervas daninhas ou insetos. Será que alguém acredita que é possível lançar tal bombardeio de venenos na superfície da Terra sem torná-la imprópria para toda a vida? Eles não deviam ser chamados 'inseticidas', e sim de 'biocidas' (CARSON, 2010, p. 23-24).

Carson trouxe prestígio ao conceito de ecologia, influenciado gerações. Foi além de denunciar os efeitos do DDT, escrevendo sobre o direito moral de cada cidadão saber o que estava sendo lançado de forma irresponsável na natureza pela indústria química. E foi mais além: despertou a consciência ambiental de uma nação para reagir e exigir explicações e soluções.

A publicação de Primavera Silenciosa foi decisiva para outros estudos que levaram à proibição do DDT nos EUA no início da década de 1970, e em outros países, ainda na mesma década. No Brasil, o DDT teve sua retirada do mercado em duas etapas: em 1985, quando sua autorização foi cancelada para uso agrícola; e em 1998, quando foi proibido para uso em campanhas de saúde pública. Finalmente, em 2009, teve seu banimento definitivo. Com a Lei 11.936/2009, ficou proibida sua fabricação, importação, exportação, manutenção em estoque, comercialização e uso no país.

Outros produtos químicos reconhecidos cientificamente como danosos à saúde pública e ao meio ambiente, proibidos em outros países, continuam em circulação no Brasil. Segundo a Agência Nacional de Vigilância Sanitária (Anvisa), dos cinquenta agrotóxicos mais utilizados nas lavouras de nosso país, 22 são proibidos na União Europeia, o que faz do Brasil o maior consumidor de agrotóxicos já banidos de outros países².

A questão dos agrotóxicos, filha que é da chamada Revolução Verde nos tempos da Primavera Silenciosa de Rachel Carson, reconfigura-se hoje no contexto da modernização agrícola conservadora e desta civilização do capital destrutiva e espoliadora. Possa esse cinquentenário grito de alerta romper o silêncio e renovar as forças sociais comprometidas com a vida.

\section{As implicações socioambientais e econômicas do desenvolvimento agrário brasileiro}

O modelo de produção agrária atualmente hegemônico no Brasil, marcado pela entrada do capitalismo no campo e pela Revolução Verde que lhe dá sustentação, revela-se perverso em seu modo de apropriação/exploração/expropriação da natureza e da força de trabalho. O agrotóxico é uma expressão de seu potencial morbígeno e mortífero, que transforma os recursos públicos e os bens naturais em janelas de negócios.

${ }^{2}$ Para maiores informações, consultar a Parte 1 deste dossiê. 
Autores como Breilh (2008, p. 15) alertam que

o espaço privilegiado onde adquiria maior densidade a acumulação de capital eram as cidades, com todo o excesso de problemas ecológicos que isto acarretou para os espaços urbanos, mas agora a essa problemática se soma o rápido avanço da transnacionalização rural e novas sequelas para os ecossistemas rurais.

Tal enfoque se contrapõe ao de autores que na década de 1980 analisaram a relação entre os espaços urbanos os rurais (CASTAN; TARGA, 1983). O novo padrão descrito por Breilh (2008) envolve a expansão dos latifúndios agroindustriais de alta complexidade tecnológica e com alto grau de externalidades negativas, como também afirmam Soares e Porto (2007) em referência ao uso de agrotóxicos no cerrado brasileiro. Tais externalidades estão relacionadas aos danos ambientais e à saúde humana cujos custos acabam por ser socializados (CARNEIRO, 2007).

Breilh (2008) reconhece que, nesses contextos, na raiz da dominação social residem processos estruturais de um novo modelo de acumulação de capital, definido por Harvey (2005) como acumulação por pilhagem. A lógica desse modelo já não trabalha apenas mediante a extração de mais-valia e os tradicionais mecanismos de mercado, mas mediante práticas predatórias, a fraude e a extração violenta, que se aplicam aproveitando as desigualdades e assimetrias entre os grupos sociais, para pilhar os recursos dos mais frágeis.

Esses grupos desfavorecidos vivem um processo de "vulnerabilidade populacional" que, segundo Porto (2012), corresponde aos grupos sociais que são mais vulneráveis a certos riscos, em função de sua classe, gênero, origem étnica ou ainda à sua inserção em territórios e setores econômicos particulares. Portanto, tal conceito não se refere apenas aos grupos de maior exposição, mas às dificuldades de tais grupos para reconhecer, tornar públicos e enfrentar os riscos, influenciando os processos decisórios que os afetam. Configura-se, assim, um ciclo que só se mantém à custa do referido modelo, que vem se intensificando no contexto da globalização e do capitalismo contemporâneo.

No Brasil há dois ministérios da Agricultura. Um se dedica ao agronegócio e o outro, ao produtor familiar. Tudo começou em 1996, quando o presidente Fernando Henrique Cardoso criou o Programa Nacional de Fortalecimento da Agricultura Familiar (Pronaf). Sua ideia foi carimbar uma fatia dos recursos do crédito rural, obrigando à sua aplicação nos pequenos produtores, inclusive os assentados da reforma agrária. Tradicionalmente, os grandes proprietários abocanham todo o dinheiro para financiamento rural. Quando Lula assumiu, porém, achou por bem transferir a gestão do Pronaf, atribuindo-a ao ministério que cuida da reforma agrária.

O Ministério do Desenvolvimento Agrário passou a operar o Pronaf. Um grave problema, porém, surgiu dessa medida. Ao apartar o atendimento aos pequenos agricultores em outra pasta, criou-se uma dicotomia. A polarização acirrou a distinção entre agronegócio e agricultura familiar. Uma política ambígua para dar resposta às pressões da globalização. 
A compreensão profunda da origem sistêmica das contradições que marcam a expansão do agronegócio, os processos dos grandes empreendimentos tais como os complexos siderúrgicos, a transposição do rio São Francisco, a produção hidroelétrica como a de Belo Monte no estado do Pará, a exploração mineral e suas implicações para a vida dos povos da floresta e do campo e para a saúde humana requer uma ciência engajada e cidadã. Vale dizer, uma academia militante da vida, comprometida com o desenvolvimento de conhecimentos que atendam à necessidade das populações, na perspectiva de um novo modelo de sociedade que supere a crise civilizatória que vivemos. Nesse caminho, a ecologia e a economia política são importantes campos disciplinares a serem considerados (PORTO, 2012) ${ }^{3}$.

Delgado (2012) situa esse debate no campo da contra-hegemonia. A visão agrária da década de 1980 deve ser revista à luz da globalização. Segundo o autor, está em curso uma especialização primária exportadora como projeto hegemônico de acumulação de capital, impondo limite ao desenvolvimento, e é nesse contexto que se deve enfrentar, como uma questão mais ampla, mais geral, a expansão do uso dos agrotóxicos ora em discussão.

No quadro de possibilidades e dificuldades da última década, vê-se, primeiramente, a inserção da economia brasileira como resposta à estagnação econômica das duas décadas precedentes, as quais estiveram marcadas pela gestão da dívida externa, que se tornou muito mais complicada após a crise cambial de 1999. A saída dessa crise é articulada pelo Brasil como nova forma de inserção na divisão internacional do trabalho (DELGADO, 2012).

Assim ingressamos como provedores de bens primários no comércio mundial. O Brasil passou a gozar de um fluxo contínuo de capitais externos, a fazer reservas, e isso tem sido apresentado como a salvação da pátria pela via conservadora, sem mudanças estruturais. O país ingressa no modelo primário e exportador, dentro de um ciclo econômico mundial liderado pela China.

No segundo governo FHC rearticula-se o processo de modernização técnica da agropecuária, que se fizera pelos militares nos anos 1960 e 1970. Reestrutura-se a aliança das cadeias agroindustriais, da grande propriedade fundiária e do Estado promovendo um estilo de expansão agrícola, sem reforma social. Agora esse pacto se dá com uma nova inserção externa e com um projeto de hegemonia política, que se inicia no segundo governo FHC e se amplia e se intensifica no primeiro e segundo governos Lula. E continua no governo Dilma (DELGADO, 2012).

Esse pacto de economia política nesta fase recente da história trouxe um poder sem par no período republicano ao setor rural, acompanhado de grande poder midiático,

${ }^{3}$ Nos dias 4 e 5 de junho de 2012 realizou-se, na Fiocruz, no Rio de Janeiro, o Seminário de Enfrentamento aos Impactos dos Agrotóxicos na Saúde Humana e no Ambiente. O rico debate travado na primeira mesa desse seminário levou a equipe de formulação deste dossiê a transcrever as falas dos professores-pesquisadores Guilherme Delgado e Horácio Martins, submetendo o texto aos autores para validação e complementação, e, com a autorização de ambos, destacamos aqui os principais aspectos então debatidos. 
parlamentar e acadêmico que enreda o Estado brasileiro em um conjunto de políticas de acumulação de capital pelo setor primário, o qual captura recursos primários e renda fundiária ligada ao setor externo. Um processo altamente concentrador da propriedade e da renda fundiária para responder a uma pressão externa por ajustamento das transações de mercadorias e serviços.

No atual estágio de nossa dependência externa, esse modelo apela para a superexploração de recursos naturais, a concentração fundiária e o "descarte" de populações campesinas, mobilizados para suprir, com produtos primários exportáveis, o déficit da indústria e de serviços e responder ao enorme desequilíbrio externo gestado pela própria especialização (DELGADO, 2012).

Foram eleitos alguns segmentos das cadeias agroindustriais (agronegócios) e minerais relacionadas com as commodities: a soja, o algodão, as carnes/rações, celulose/ papel, etanol/açúcar, ferro, café, laranja, tabaco, alumínio, manganês e bauxita. O petróleo, que também é uma commodity, tem outra dinâmica de crescimento industrial, mas também fica sujeita à superexploração e aos riscos ambientais.

A agropecuária é capturada pelo comércio mundial, e sua expansão se dá de duas maneiras: pela expansão horizontal das áreas de lavoura, especialmente nos últimos dez anos, que vêm crescendo em média 5\% ao ano; pela intensificação do pacote tecnológico da Revolução Verde. Isso explica a duplicação do consumo interno de agrotóxicos no período de 2003 a 2009. As vendas cresceram 130\%, sem nenhum componente de inovação técnico-industrial ou de pesquisa de ponta. São elevados e insustentáveis os custos sociais desse modelo de expansão agrária, assim como os da extração do petróleo, que tem como característica a superexploração da natureza (DELGADO, 2012).

A solução imediata para o déficit de conta corrente e saída da crise com que nos defrontamos em 1999, buscada em empréstimos do Fundo Monetário Internacional (FMI), levou à aceleração das exportações primárias, principalmente de componentes agrícolas, de minerais e de produtos de leve beneficiamento industrial. Isso levou à geração imediata de superávits nas transações externas durante o período de 2003 a 2007, criando certa euforia passageira. Mas já em 2008 recrudesce o déficit externo (na conta corrente com o exterior), que tem sido relativizado pelo ingresso de capitais externos, o qual ainda não apareceu como um grave problema na economia. No entanto, a gravidade de tudo isso se expressa de duas maneiras: na dependência de capital estrangeiro, por um lado, e na ampliação dos custos sociais desse estilo de crescimento, por outro. Os custos sociais da especialização econômica do setor primário ainda não estão suficientemente percebidos pela sociedade (DELGADO, 2012).

Recentemente, na tramitação legislativa do novo Código Florestal, ficou evidenciada a imposição dos conceitos ruralistas - recurso natural visto como matéria-prima à disposição do capital, em contraposição ao pensamento contra-hegemônico, que estabelece limites de interesse público. A bancada ruralista e o governo federal brasileiros estão associados de forma contraditória ao capital externo, evidenciando que uma par- 
te do setor industrial tende a diminuir substancialmente sua importância como polo dinâmico da economia brasileira caso se mantenha esse padrão de acumulação pelo setor primário. Este explora vantagens comparativas naturais e se beneficia de custos sociais e ambientais exacerbados, perante uma sociedade sem capacidade de colocar limites a esse padrão. Tal processo, que tem sido viabilizado nos últimos três governos, trouxe de volta a modernização técnica sem reforma, uma engenharia política que convence a sociedade de uma saída exitosa, no sentido da hegemonia política segundo Gramsci (DELGADO, 2012).

O pacto do agronegócio foi introduzido com a conquista de mentes e corações pela mídia, pela academia e pela política com representação no Congresso (bancada ruralista), como salvação da pátria - um modo mais ardiloso e, portanto, mais difícil de combater (DELGADO, 2012). Por outro lado, há o Brasil real, com uma população ativa de 105 milhões de pessoas. Esse padrão de acumulação pelo setor primário não tem condições de resolver os problemas de emprego, da urbanização complexa da sociedade e ainda manter a indústria como um polo dinâmico de inovação, pois esta tem se deslocado para a propriedade das terras e para a apropriação da renda fundiária, os grandes filões da acumulação de capital. Isso é conservador e predador em vários aspectos. Denunciar as consequências ambientais e sanitárias desse estilo de crescimento é útil e necessário para esclarecer a sociedade e criar condições de mudança estratégica (DELGADO, 2012).

No processo de aprovação do recente Código Florestal ficou, mais uma vez, evidente a aliança do poder federal com o setor agrário. Refém da bancada ruralista e do pacto de acumulação de capital primário, o que resta à sociedade brasileira? Tentar a desarticulação desse pacto, criando novas alianças e posições. As vantagens com práticas naturais de produtos primários são um campo a ser explorado para essa contraposição.

Delgado (2012) complementa:

Em tais condições, para viabilizar, no plano externo, o volume e o ritmo de crescimento dos saldos comerciais primários, necessários à solvência externa da conta corrente, haverá uma pressão endógena desse sistema por superexploração dos recursos naturais. A isso também se soma a pressão por concentração da propriedade fundiária, que é também forma peculiar de captura da renda da terra. Esses são os elementos cruciais que caracterizam a apropriação da renda fundiária, com consequências agrárias e ambientais altamente negativas.

Há uma dupla pressão por obtenção de ganhos de produtividade com recursos naturais. De um lado, a incorporação de novas áreas ao espaço econômico explorado, atual e potencialmente. Nesses novos territórios, a expansão agrícola se inicia adotando pacote tecnológico preexistente e exercendo um consumo crescente de recursos naturais não produzidos pelo trabalho humano - solos, água, biodiversidade, florestas nativas, luminosidade, condições 
climáticas etc. De outro lado, nas zonas de agricultura já consolidada, haverá certamente pressão crescente por aumento de produtividade do trabalho mediante intensificação do pacote tecnológico agroquímico, com consequências ambientais também predatórias sobre o meio ambiente.

Por sua vez, na dinâmica de crescimento da produtividade física da agropecuária nas zonas consolidadas ou nas zonas de nova incorporação fundiária, não há evidência de correspondência com aumentos de salário, nem tampouco de elevação do emprego de trabalhadores não qualificados, vinculados ao crescimento da produção. Em outros termos, a taxa de salário, o emprego e a massa salarial gerados no processo de produção e exportação de bens primários $^{4}$ não crescem ou até decrescem, enquanto que a produção e a exportação das principais cadeias agroindustriais se expandem a elevadas taxas de 8 a $10 \%$ ao ano.

Conquanto o trabalho humano venha sendo crescentemente mitigado nos processos produtivos tipicamente capitalistas ou de agronegócio, as relações de trabalho que se estabelecem na produção agropecuária parecem configurar um estilo de superexploração, seja pela imposição de jornadas excessivas (corte de cana, por exemplo), seja pelo manejo de materiais agrotóxicos altamente nocivos à saúde humana, seja pelas relações de precária contratação de trabalhadores migrantes nos picos da demanda sazonal das safras agropecuárias.

A superexploração do trabalho aqui referida, assim como a superexploração dos recursos naturais, se amalgama na abordagem histórico-concreta do agronegócio brasileiro dos anos 2000. Nesse sentido, é conceito útil e necessário para caracterizar o padrão de extração do excedente econômico que se realiza no quadro de relações internacionais fortemente assimétricas.

Algumas evidências empíricas da dupla superexploração: do trabalho e dos recursos naturais. Já existe alguma evidência empírica de que o padrão de exploração dos recursos naturais e do trabalho humano na economia do agronegócio nesta primeira década do século XXI sugere uma dupla superexploração. No primeiro caso, alguma verificação se extrai da constatação, fortemente comprovada pelo Ibama, da violação sistemática da norma ambiental-florestal exigida sobre limites da Área de Reserva Legal (florestal) e da Área de Preservação Permanente (mata ciliar, de topos e encostas de morros). Este, dentre outros ilícitos, tem sido recorrentemente verificado, a ponto de provocar sucessivos decretos de prorrogação dos prazos de punição, previstos em lei (Código Florestal), no aguardo de uma revisão legislativa que os ruralistas tentam aprovar

\footnotetext{
${ }^{4}$ Segundo informação dos censos agropecuários de 1996 e 2006, o "Pessoal ocupado" na agropecuária decresceu na década intercensitária (-7,2\%), passando de 17,85 milhões de pessoas em 1996 para 16,57 milhões em 2006.
} 
no Congresso a qualquer custo (Projeto de Lei n. 1.876/99, aprovado na Câmara Federal, modificado no Senado Federal e ora em tramitação de retorno na Câmara Federal, em princípios de 2012).

Por outro lado, ainda considerando a superexploração de recursos naturais, há dois outros vetores de degradação do meio ambiente que se associam ao estilo de expansão agropecuária das commodities, sobre as quais se dispõe de sólida evidência empírica: a) o aumento físico de queimadas e desmatamentos, tecnicamente responsáveis pela emissão de dióxido de carbono na atmosfera, e b) a intensificação do uso de agrotóxicos na última década, com forte evidência de vários tipos de contaminação.

Observe-se que aos vários tipos de perda ou degradação de recursos naturais identificados correspondem formas peculiares de pressão pela utilização extensiva ou intensiva da terra. Nos dois primeiros exemplos citados - violação de normas do Código Florestal - e no segundo - desmatamentos e queimadas -, a pressão é por incorporação legal ou ilegal de áreas novas (uso extensivo), dentro e fora da fronteira agrícola. Por sua vez, no terceiro caso - a intensificação do uso de agrotóxicos -, a forma de deterioração de recursos é tipicamente de outra natureza (uso intensivo), qual seja, reflete a pressão por obtenção de rendas fundiárias extraordinárias, mediante intensificação das tecnologias associadas ao uso dos agrotóxicos e fertilização química, associadas a variedades biológicas adaptadas.

Se combinarmos os efeitos da emissão de dióxido de carbono, da redução de biodiversidade e da expansão acelerada dos agrotóxicos, temos vários componentes de morbidade potencial, tanto ambiental quanto humana, que não entram no cálculo privado da produção agrícola, mas provocam evidentes custos sociais. Estes precisam ser conhecidos, avaliados e, principalmente, evitados.

Carvalho (2012) traz uma indagação primeira: o que aconteceu neste país que lhe permitiu chegar a este ponto, no qual um bilhão de litros de agrotóxicos é consumido por ano? Por que se permitiu a prática de concentração oligopolista das empresas que ofertam mundialmente agrotóxicos, como Syngenta, Bayer, Basf, Dow, DuPont e Monsanto? O que levou a esse processo? Para o pesquisador, a prática desse oligopólio mundial de agrotóxicos na agricultura brasileira se deveu ao modelo econômico e tecnológico implantado no país que se denominou de modernização conservadora no campo a partir de 1965 e reforçada, porque atualizada, desde 1990 até os dias atuais.

Para que esse modelo econômico e tecnológico fosse adotado pelas grandes empresas capitalistas no campo, foi necessário um conjunto articulado de medidas governamentais e legislativas, em particular a instituição do crédito rural subsidiado pelos governos.

Nesse ritmo de consumo de venenos, estamos caminhando para uma sociedade insana, consumidora em escala considerável de produtos químicos que, destinados a 
eliminar o que o modelo técnico-científico dominante considera como pragas e doenças das plantas e dos animais, acabam por contaminar também os alimentos e reduzir a biodiversidade (CARVALHO, 2012).

Esse processo de utilização de agrotóxicos na agricultura, iniciado muito antes de 1965, mas, a partir dessa data, empregado de maneira massiva e indiscriminada, teve amplo respaldo dos governos, então no âmbito da ditadura civil-militar. E se afirmou e se reforçou pós-1990 na dinâmica de privatização dos organismos governamentais, de tal maneira que se torna possível afirmar que estamos na vigência de um Estado máximo para o capital e mínimo para o povo (CARVALHO, 2012).

Em contrapartida a esse Estado forte para o capital, ampliaram-se as políticas públicas compensatórias, de maneira a suscitar uma "consciência feliz" e consumidora das massas, mesmo as mantendo exploradas e subalternas (CARVALHO, 2012). É deveras improvável que a ampliação desmesurada do consumo de agrotóxicos na agricultura tivesse ocorrido, por um lado, sem o apoio inconteste do Estado e, por outro, sem que um processo político-ideológico de cooptação popular e desmobilização política tivesse sido estimulado, de maneira a facilitar o afloramento dos valores neoliberais, entre os quais o consumo do efêmero e a perda da memória histórica. Apesar do clamor dos ambientalistas e de alguns setores populares mais atentos à sanidade dos alimentos, é possível sugerir que, mantida a atual tendência dominante, é muito provável que estejamos no caminho da barbárie (CARVALHO, 2012).

Constata-se forte concentração entre as empresas capitalistas no campo, ou a elas relacionadas, através da disputa e de acordos para fusões e aquisições de empresas da agroindústria, assim como para a aquisição privada da terra agricultável (CARVALHO, 2012). Em 2003, 112 mil imóveis concentravam 215 milhões de hectares. Em 2010, 130 mil imóveis concentravam 318 milhões de hectares. Portanto, em sete anos, mais de cem milhões de hectares passaram para o controle de grandes empresas, de latifundiários. Todavia, apenas um quinto das posses de imóveis rurais tem documentos legais que permitem dizer que são de fato propriedade privada de alguém (CARVALHO, 2012).

As terras agricultáveis brasileiras, assim como a natureza em sentido amplo (mananciais, biodiversidade dos vários biomas, rios, litoral...), estão cada vez mais nas mãos do capital monopolista internacional, seja como reserva de valor, seja para a exploração econômica. Cresce o número e se diversifica a origem dos capitalistas interessados em investir em terras agricultáveis (CARVALHO, 2012).

Como em outras regiões do mundo, há um processo crescente de apropriação privada da natureza, em detrimento das distintas formas de apropriação social e/ou pública. E é insuficiente a regulação dessas iniciativas a partir do Estado. Não há dúvida de que a correlação de forças econômicas e políticas é muito desigual, mas os resquícios das estratégias de privatização tanto das instituições governamentais como do patrimônio público estão presentes nessa cessão indireta da soberania nacional (CARVALHO, 2012). 
O governo federal retirou a reforma agrária da agenda política. E, consoante com os resquícios político-ideológicos da privatização, ensaia reduzir as áreas das Áreas de Preservação Permanente (APPs), das reservas indígenas e dos territórios quilombolas. Diversos trechos do litoral já estão em situação de fato de propriedade privada, ainda que ao arrepio da lei, assim como inúmeras áreas isoladas no mar têm sido apropriadas para a carcinicultura e a ostreicultura (CARVALHO, 2012).

O crescimento acelerado dos investimentos estrangeiros para a apropriação privada direta ou o arrendamento de terras agricultáveis em várias regiões do mundo provocou, em 26 de abril de 2010, em Washington DC, durante a conferência anual de terras do Banco Mundial, a realização de uma mesa-redonda, tendo como anfitriões Japão, Estados Unidos e a União Africana, para debaterem e aprovarem uma proposta elaborada pelas agências multilaterais - Banco Mundial, Food and Agriculture Organization (FAO), Conferência das Nações Unidas sobre Comércio e Desenvolvimento (Unctad) e Fundo Internacional de Desenvolvimento Agrícola (Fida) - de um Código de Conduta $(\mathrm{CdC})$ para orientar os investimentos agrícolas no mundo. Entre os diversos pontos desse $\mathrm{CdC}$, destacam-se: transparência nas negociações, respeito aos direitos existentes, sustentabilidade ambiental e adesão a políticas comerciais nacionais (CARVALHO, 2012).

Estamos no meio de uma longa onda histórica de neocolonialismo, em que a mercantilização da natureza (a natureza como negócio), a artificialização da agricultura, a crescente presença de organismos geneticamente modificados (OGMs) e as decisões político-comerciais dos oligopólios que definem a matriz produtiva nacional na agricultura, além da redução do Estado e o estímulo a um suposto livre-cambismo, tornam o Brasil uma das principais economias do mundo, mas com pés de barro.

A artificialização das técnicas produtivas (OGMs, fertilizantes de origem industrial, uso de agrotóxicos), tendo como sustentação diversas políticas públicas, facilita a expansão e a acumulação capitalista da agricultura. É tanto dinheiro oferecido pelos governos aos negócios na agricultura e agroindústria que chega a ser imoral. Somente nessas condições se explica que o agronegócio receba cerca de $\mathrm{R} \$ 90$ bilhões de crédito para gerar um Produto Interno Bruto (PIB) de R $\$ 120$, de um total do PIB agrícola de R \$ 160 bilhões. E, mais ainda, as dívidas agrícolas de 2005 a 2008 geraram 15 leis e 115 atos do Conselho Rural para sua renegociação. Um grande favorecimento aos aliados dos grupos econômicos transnacionais de insumos (CARVALHO, 2012).

Não é, então, de estranhar que no Brasil o mercado de agrotóxicos esteja controlado por seis grandes grupos transnacionais: Syngenta, Bayer, Basf, Dow, DuPont e Monsanto. E que a oferta de fertilizantes esteja concentrada em três grupos transnacionais, controlada desde 2007 pelos grupos Bunge (Amsterdam e Nova York), Yara Internacional ASA (Oslo) e Mosaic (EUA, principalmente fósforo e potássio). Não é demasiado relembrar que em 1992 as empresas estatais Ultrafértil e Fosfértil, ambas da Petrobras, controlavam a oferta de fertilizantes no país. 
O comércio varejista de alimentos também é controlado pelos grupos econômicos transnacionais. Vinte e seis por cento do comércio varejista estão nas mãos de empresas transnacionais como a Nestlé, a Pepsi e a Coca-Cola (CARVALHO, 2012).

Essa situação oligopolista, determinada por grandes grupos econômicos transnacionais dos setores de insumos e de produtos agropecuários e florestais, influencia de forma consistente o comportamento dos governos cujas estratégias a médio e a longo prazos se revelam como de facilitação da expansão e da reprodução ampliada do capital na agricultura (entre outros setores). Essa dinâmica de expansão e consolidação da grande empresa capitalista no campo nos faz indagar sobre onde estarão o proletariado rural e os camponeses. Qual é a perspectiva estratégica de superação dessa dinâmica de concentração e centralização da apropriação privada da natureza, da oferta de insumos e de produtos da agricultura no país?

Segundo Carvalho (2012), para superar a elevada utilização de venenos na agricultura é necessário dar conta dessa correlação de forças econômicas, políticas e ideológicas no campo, sempre levando em consideração a grande relevância do problema da concentração dos registros de patentes, enquanto direitos e obrigações relativos à propriedade industrial: as 27 corporações internacionais que começaram as pesquisas sobre plantas tolerantes a herbicidas e a insetos são detentoras do maior número de depósitos de patentes (CARVALHO, 2012).

A indústria química está por detrás das ciências da vida e da morte (agrotóxicos). Por ironia da lógica capitalista, os agrotóxicos, denominados pelos empresários rurais de defensivos agrícolas, são produtos do campo das ciências da vida, ainda que, paradoxalmente, "combater as pragas" signifique destruir a biodiversidade. Na raiz do uso de agrotóxicos está o modelo econômico capitalista cuja racionalidade fundamenta o uso massivo de venenos no âmbito de uma permissividade que destrói a vida em nome do combate às pragas e do controle de doenças na agricultura.

Para avançar no enfrentamento dessa lógica, é necessária não somente outra postura, mas, também, outro discurso. É indispensável deixar claro que a agroecologia, como síntese de diversas alternativas ambiental e socialmente apropriadas e contrárias ao padrão tecnológico dominante, tem como efetiva base produtiva o campesinato contemporâneo, hoje representando 4,5 milhões de estabelecimentos rurais.

Nessa perspectiva, é necessária uma nova leitura do campo. É preciso reconsiderar o campesinato à luz da construção da sua autonomia relativa perante o capital, de uma relação de coevolução no processo de produção e de interação com a natureza, e vislumbrar outras formas de cooperação, outra cultura que não a hegemônica (CARVALHO, 2012) ${ }^{5}$.

Almeida (2012) refere-se ao tipo de ciência que está atrelado ao modelo químico/ biotecnológico-dependente do agronegócio. E pergunta: que alternativas contra-hege-

\footnotetext{
${ }^{5}$ Aos interessados em aprofundar o estudo sobre campesinato, apresentamos no Anexo IV, como
} sugestões de leitura, uma lista de títulos bibliográficos relacionados ao tema. 
mônicas estão sendo construídas para a produção agroecológica? Não só agrotóxico mata, o agronegócio também.

Segundo Sauer (2008, p. 20), a expressão "agricultura familiar" se popularizou no Brasil em meados da década de 90, traduzida do modelo norte-americano, e ganhou espaço no movimento sindical e nas esferas governamentais e acadêmicas a partir de pesquisas da FAO e do Programa das Nações Unidas para o Desenvolvimento (Pnud) realizadas à época em convênio com o Ministério da Agricultura brasileiro e o Instituto Nacional de Colonização e Reforma Agrária (Incra).

Não é nossa proposta analisar aqui os impactos das políticas de financiamento para a agricultura familiar, promovendo maior ou menor autonomia dos agricultores em relação ao mercado de capitais e de produtos agrícolas. No entanto, este tema assume importância no debate sobre os impactos dos agrotóxicos na saúde do trabalhador (WEID, 2010). É importante observar a iniquidade do financiamento quando comparado ao financiamento público para o agronegócio, que consome mais de $90 \%$ de todo o recurso disponibilizado pelo governo. Um disparate, pois a agricultura familiar é responsável por abastecer a mesa da população brasileira de alimentos.

A agricultura familiar camponesa tem seu modo de produção fundado em diversidade produtiva, em economia de escopo, em territórios política e socialmente estabelecidos, e é viabilizada pelo encurtamento das cadeias de produção e comercialização. Muitos setores, inclusive vinculados à noção de agricultura familiar, se distanciam dessa identificação camponesa para, paradoxalmente, se contrapor ao agronegócio e sua voracidade por recursos públicos.

"Invisível" para a ciência e para a mídia, o mundo da agricultura familiar envolve muito mais camponeses do que é reconhecido. Em todo o mundo, tais camponeses somam algo em torno de 1,2 bilhão de pessoas (PLOEG, 2008, p. 25).

A noção de territorialidade é tão central para a agricultura camponesa que Carvalho (2012) a define em função do território, no contexto de relações sociais que se expressam em regras e instituições de uso das disponibilidades naturais (capacidades difusas internalizadas nas pessoas e aparatos infraestruturais tangíveis e intangíveis), em determinado espaço geográfico politicamente delimitado.

Na racionalidade econômica pretensamente verde do modelo capitalista, a divisão do espaço concebe apenas dois espaços possíveis: um onde tudo (supressão da vegetação, contaminação química de rios, lagos, solo, ar e pessoas, destruição do solo) pode ser feito desde que demarcada a posse de um lugar, e outro em que nada pode ser feito (natureza preservada), como compensação à destruição causada nos locais onde se desenvolve a agricultura empresarial-capitalista. Está aí a noção da "agricultura verde" colocada no mercado, à venda para as empresas do setor interessadas em adquiri-la (LEROY, 2011).

Caldart e colaboradores (2012) se referem ao "território camponês" como espaço de vida, local de residência da(s) família(s), predominantemente agropecuário, que contribui com a maior parte da produção de alimentos saudáveis, consumidos princi- 
palmente pelas populações urbanas. No modo camponês de fazer agricultura, a lógica é a produção de máximo valor agregado possível, com, fundamentalmente, recursos autocriados e automanejados, e a coprodução entre o homem e a natureza viva torna-se um fator decisivo para o fortalecimento continuado da base de recursos e a consequente redução da dependência de insumos externos (PLOEG, 2008). Aí esta a chave para a compreensão da sustentabilidade intrínseca da agricultura familiar camponesa e, por que não acrescentar, de base agroecológica.

Como ciência, a agroecologia emerge da busca de superação do conhecimento fragmentário, compartimentado, cartesiano, em favor de uma abordagem integrada. Fornece os princípios ecológicos básicos para estudar, desenhar e manejar agroecossistemas produtivos, conservadores de recursos naturais, culturalmente apropriados, socialmente justos e economicamente viáveis, proporcionando bases científicas para apoiar processos de transição a estilos de agriculturas de base ecológica ou sustentável (CALDART et al., 2012).

No contexto da "economia verde", a proposta de "desenvolvimento" baseada na transgenia se apresenta como capaz de minimizar os efeitos ambientais nocivos da Revolução Verde. Mas trata-se de mais um engodo, posto que o agroquímico faz parte do pacote tecnológico, da venda casada de semente geneticamente modificada e do agrotóxico para o qual é resistente. Graças à soja transgênica, o Brasil passou a recordista mundial no mercado de agrotóxicos.

Segundo Rigotto (2011), a posição alcançada pelo Brasil como maior consumidor mundial de agrotóxicos está inserida em um contexto de reestruturação produtiva no plano mundial e em especial na América Latina, cabendo a países deste continente o papel de produtores de commodities para o mercado internacional.

Não são raras as confusões com o uso do termo "agroecologia" vinculado a ideias reducionistas de "adoção de práticas ou tecnologias agrícolas", "modelo de agricultura", "oferta de produtos limpos ou ecológicos", entre outras associações, que, mesmo na eventualidade de uso bem-intencionado, constituem um erro tanto científico quanto político no que diz respeito à agroecologia (CAPORAL; COSTABEBER, 2007).

Longe das falsas soluções técnicas oferecidas ao mercado por empresas do agronegócio, e considerando que, diante da disponibilidade de alimentos hoje no mundo, a fome já não deveria ser mais uma realidade nas proporções ainda vigentes, o combate à fome e pobreza extrema exige, na verdade, o enfrentamento de suas causas profundas, as quais se encontram na lógica de dominação das grandes empresas e corporações do agronegócio.

Tais organizações globais e nacionais não se intimidam em usurpar plantas cultivadas pela humanidade há milênios, ameaçando a soberania alimentar de povos de todo o planeta, para delas se apropriar na forma de patentes. Não contêm sua criatividade na invenção de "mercados verdes", e muito menos se envergonham de "justificar" o uso do agrotóxico como "um mal necessário" diante do desafio da fome no mundo que elas mesmas criaram e que mantêm, porque dá lucro. 


\section{O consumo de agrotóxicos no Brasil}

O cenário do mercado de agrotóxicos, atualizado para 2010, mostra que nesse ano houve um acréscimo de $190 \%$. As maiores empresas que controlam esse mercado são multinacionais instaladas no Brasil: Basf, Bayer, Dupont, Monsanto, Syngenta, Dow. Em 2010, eram 22\% na América Latina, sendo 19\% no Brasil, o maior mercado de agrotóxicos do mundo, seguido pelos EUA. Observam-se acordos e fusões de empresas que dominam ao mesmo tempo o mercado de agrotóxicos e de sementes. A estrutura de mercado mostra os acordos comerciais entre as empresas, tais como os da Bayer com a Monsanto e da Basf com a Monsanto (núcleo controlador dos acordos de todos). No entanto, muitos deles envolvem acordos públicos com a Empresa Brasileira de Pesquisa Agropecuária (Embrapa). O montante mobilizado é maior que o PIB de vários países, o que os constitui como verdadeiros oligopólios. Há um mercado dos registros de agrotóxicos mediados por empresas de fachada.

A partir de 2008, a taxa de crescimento da importação de princípios ativos foi de $400 \%$ e a de produtos formulados, de $700 \%$. Estão cadastradas 130 empresas, das quais 96 são apenas para comercialização; 53\% não têm a menor capacidade produtiva, são apenas importadoras, com escritórios no Brasil, mobilizando a venda de 833.000 toneladas de 936 produtos. Noventa por cento dos produtos formulados são de material vindo de outros países, especialmente da China. Quarenta e quatro por cento das vendas são diretas aos clientes, 24\% para a indústria e 32\% para revenda. Esse comércio está sem fiscalização (ANVISA; UFPR, 2012).

O registro de um agrotóxico é ad eternum, pois não existe o procedimento de atualização do registro definido por períodos, como ocorre no caso dos medicamentos, em que a cada cinco anos a concessão é revisada para manutenção ou revogação da autorização. Em alguns países a atualização periódica do registro está prevista, o que possibilita ao órgão avaliador proceder de forma ágil às alterações sobre decisões tomadas anteriormente.

O custo pago para registro no Brasil é baixíssimo. Enquanto para a Anvisa são pagos 1.800 reais, nos EUA são pagos 600 mil dólares por registro. A United States Environmental Protection Agency (US-EPA), agência de proteção ambiental americana, tem 854 técnicos trabalhando na regulação de registros de agrotóxicos; o Brasil conta com apenas 21 técnicos aptos a realizar avaliação toxicológica (ANVISA; UFPR, 2012).

Em 2008 a Anvisa colocou 14 produtos em reavaliação toxicológica, iniciativa que gerou processos de judicialização por parte das empresas interessadas, o que tem dificultado a sua conclusão e mantido no mercado produtos que deveriam estar banidos do país. As fiscalizações realizadas em empresas formuladoras têm mostrado vários problemas no controle de qualidade, incluindo alterações das formulações sem registro. O Programa de Avaliação de Resíduos de Agrotóxicos (PARA) de 2010 revelou que 28\% das amostras 
foram insatisfatórias. As estratégias das empresas, além da judicialização, têm sido exercer, mediante lobby, influência sobre parlamentares e gestores como forma de pressionar as políticas de Estado. Entrou em consulta pública a revisão dos critérios de avaliação e classificação toxicológica para registro de agrotóxicos (ANVISA; UFPR, 2012).

Em decorrência desse modelo químico-dependente de agrotóxicos, a cadeia produtiva do agronegócio se configura como um processo de insustentabilidade ambiental, pois no seu espaço se cria um território com muitas e novas situações de vulnerabilidades ocupacionais, sanitárias, ambientais e sociais. Tais vulnerabilidades induzem eventos nocivos que se externalizam em trabalho degradante e escravo, acidentes de trabalho, intoxicações humanas, cânceres, más-formações, mutilações, sequelas e ainda contaminação com agrotóxicos e fertilizantes químicos das águas, do ar, da chuva e do solo em todos os espaços ou setores da cadeia produtiva do agronegócio, como indicado na figura 2.1, descrita por Pignati (2007).

Dentre os impactos à saúde relacionados ao processo produtivo do agronegócio, os de maior relevância para a saúde humana e ambiental são as poluições e/ou contaminações e as intoxicações agudas e crônicas relacionadas à aplicação de agrotóxicos, presente em todas as etapas dessa cadeia produtiva apresentadas na figura 2.1.

Devido ao modelo agrícola do agronegócio que alia o "uso e abuso" de agrotóxicos com comunicações sociais (rótulos, orientações e receituários) deficientes e com as dificuldades de percepção de perigo pelos trabalhadores e pela população, esses tóxicos atingem de maneira imediata quem vende, quem transporta e quem manipula/ pulveriza tais insumos, e indiretamente também suas famílias que moram dentro ou na periferia das plantações; também são atingidos aqueles que armazenam esses produtos dentro ou próximo de suas residências (PERES; MOREIRA, 2003; SOBREIRA; ADISSI, 2003; SILVA et al., 2005; PIGNATI; MACHADO 2011).

É interessante observar que a aplicação de agrotóxicos é, provavelmente, a única atividade em que a contaminação do ambiente de produção e trabalho é intencional. A poluição é provocada pelos fazendeiros no intuito de combater as "pragas da lavoura", seja uma erva, fungo ou um inseto, por eles consideradas como "daninha, peste ou praga", que passam a ser alvo da ação de agrotóxicos como herbicidas, fungicidas ou inseticidas. Entretanto, como essas "pragas" se reproduzem junto com a lavoura, sendo impossível separá-las ou individualizá-las, o fazendeiro ataca todo o conjunto lavoura-praga com esses biocidas na intenção de atingir aqueles alvos. Além disso, todos os agrotóxicos adquiridos estão classificados e rotulados com a indicação dos níveis de toxicidade (I a IV - extremamente tóxico, altamente tóxico, medianamente tóxico e pouco tóxico) para o homem ou o ambiente, não cabendo dúvidas ao fazendeiro e ao agrônomo que emitiu o receituário quanto à contaminação intencional que ocorrerá com o seu uso.

Nesse processo efetuam-se várias pulverizações de agrotóxicos; algumas névoas atingem o objeto, outras atingem as plantas e o solo e várias evaporam ou são levadas, pelo vento ou pela chuva, para outros locais (PIGNATI; MACHADO; CABRAL, 
Figura 2.1 - Etapas do processo produtivo do agronegócio e seus impactos na saúde do trabalhador, na população e no ambiente

Desmatamento

Derrubada de árvore

Seleção de madeiras

Seleção de lenhas

Queimadas

Motosserras, combustível, tratores

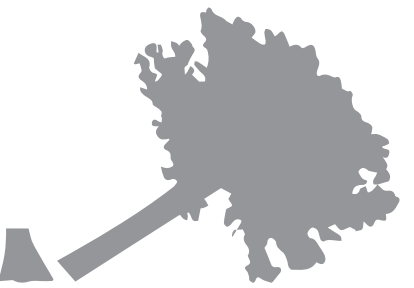

Mutilações, sequelas, doenças infectoparasitárias, acidentes com animais peçonhentos, doenças pulmonares

Fumaças, erosão do solo, biopirataria, extinção de espécies
Indústria da madeira

Serraria/tábuas/vigas

Laminadora

Fabricação de compensado, esquadros e forros

Serras, lâminas, polias, tratores

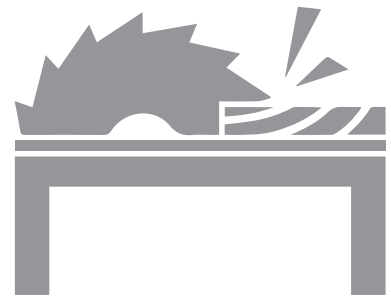

Mutilações, sequelas, hipertensão, desemprego

Pós de serra, fumaças, resíduos de agrotóxicos

\section{Agricultura}

Preparo do solo Sementes

Agrotóxicos, calcário, fertilizantes químicos

Tratores, aviões, máquinas agrícolas

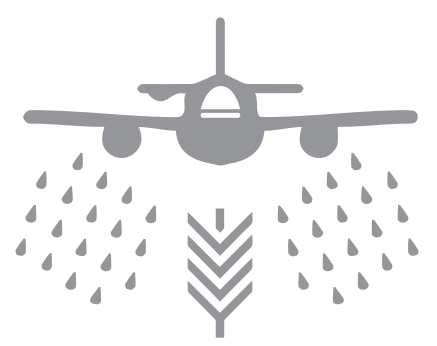

Intoxicação por agrotóxicos e fertilizantes químicos, neoplasias, más-formações

Erosão do solo, resíduos de fertilizantes e agrotóxicos, extinção de espécies

2007; MACHADO, 2008, MACHADO, 2009). O mais grave desse processo é que na agricultura, o ambiente de trabalho se confunde com o espaço global da produção. Nesse caso, como prevenir as poluições e contaminações? "Normalmente, as contaminações dos ambientes de trabalho são indesejáveis e devem ser controladas, mas como proceder quando a contaminação é a finalidade da atividade?’, pergunta Garcia (2001, p. 70). Para a prevenção dessas situações de risco, Garcia (2005, p. 14) recomenda como medida fundamental a adoção de práticas agrícolas que propiciem a redução da incidência de pragas e que, "se houver necessidade de uso de um agrotóxico, isso se dê dentro dos critérios agronômicos, ambientais e de saúde mais rígidos possíveis (o que raramente acontece)".

Esses desvios ou erros de alvo são considerados pelos fazendeiros e agrônomos como "derivas" ou acidente na aplicação por falta de treinamento, ou porque as condições climáticas mudaram rapidamente, ou ainda porque houve descuido ou um ato inseguro do pulverizador; portanto, eles culpam o clima ou o trabalhador (tratorista, piloto). Entretanto, a Embrapa acrescenta que normalmente ocorre uma "deriva técnica" 


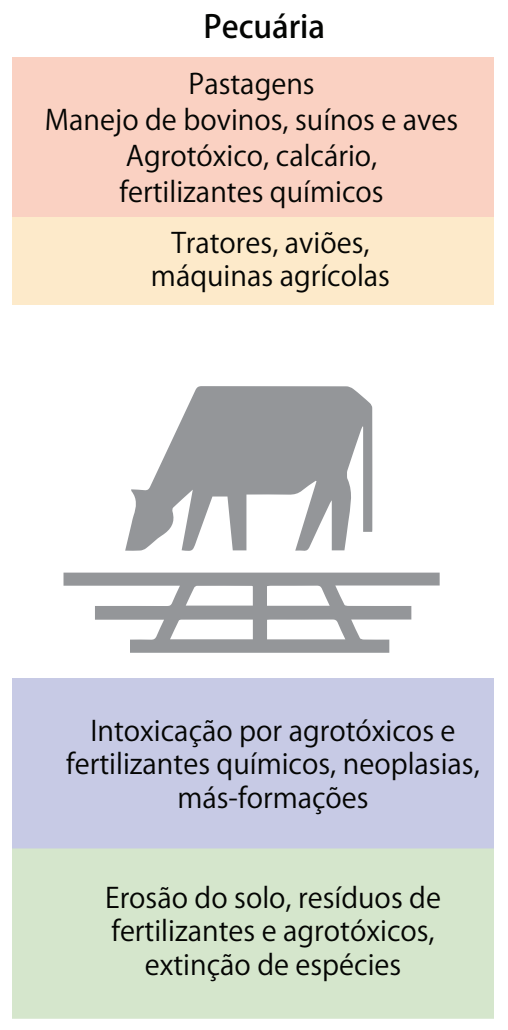

Transporte / armazenamento

Carga e descarga de cereais, gado, agrotóxicos, calcário, fertilizantes químicos

Silos, caminhões, tratores, secadores, máquinas agrícolas

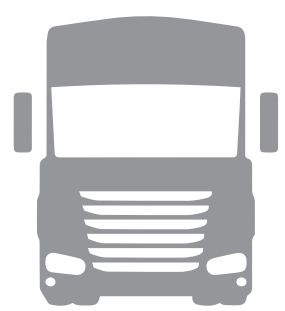

Acidentes de transporte e de trânsito, mutilações e sequelas

Poluição do ar, do solo e da água, acidentes com cargas perigosas

\section{Agroindústria}

Fabricação de óleos e farelos, açúcar/álcool, beneficiamento de algodão, curtumes

Silos, caminhões, tratores, máquinas industriais, usinas, frigoríficos

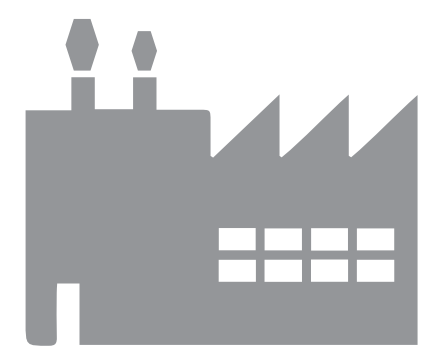

Consumo de produtos com resíduos, mutilações e sequelas

Poluição via efluentes, esgoto industrial, chaminés e outros resíduos

Fonte: adaptado de PIGNATI, 2007, p. 18.

com os atuais equipamentos de pulverização, que mesmo com calibração, temperatura e ventos ideais, deixam apenas cerca de 32\% dos agrotóxicos pulverizados retidos nas plantas; $19 \%$ vão, pelo ar, para outras áreas circunvizinhas da aplicação e $49 \%$ vão para o solo e, após algum tempo, parte se evapora, parte é lixiviada para o lençol freático e outra parte se degrada (CHAIM, 2004).

Além disso, há pulverizações intencionais nas plantações cultivadas próximo a residências, córregos, criação de animais e reservas florestais que também são classificadas erroneamente pelos fazendeiros como derivas. O que na verdade acontece, nesses casos, é que os fazendeiros desrespeitam a proibição de pulverizar nesses espaços, prevista no Código Florestal; na Lei n. 7809/89, a chamada Lei dos Agrotóxicos (BRASIL, 1989); no Decreto n. 4.074/02 (BRASIL, 2002); na Instrução Normativa do Ministério da Agricultura, Pecuária e Abastecimento (MAPA) n. 02/2008, cujo artigo 10 registra que "é proibido realizar pulverização aérea de agrotóxicos a uma distância mínima de 500 metros de residências, vilas, córregos e nascentes d'água" (BRASIL. MAPA, 2008); e no Decreto do Estado de Mato Grosso n. 2.283/2009, que em seu artigo 46 
diz "é proibido realizar pulverização terrestre (por trator ou costal) de agrotóxicos a uma distância mínima de 300 metros de residências, vilas, córregos e nascentes d'água" (MATO GROSSO, 2009).

Indagamos se, nesse modelo de desenvolvimento da agricultura químico- dependente, os fazendeiros não estão praticando um "crime doloso" provocado pelas pulverizações/poluições intencionais com agrotóxicos e outros agroquímicos. Será que eles estão se responsabilizando social e economicamente pelos impactos negativos na saúde humana e pelos danos ambientais? Será que os consumidores de alimentos estão conscientes e mobilizados para agir e cobrar alimentos, ambientes e vidas saudáveis? Onde vai parar o conteúdo de agrotóxicos que estavam nas embalagens? Nesse processo haverá contaminação das águas, do ar, da chuva, dos alimentos, do leite materno, do sangue e da urina dos humanos e dos outros animais. Portanto, não existe uso seguro de agrotóxicos na agricultura.

\section{A agricultura transgênica requer agrotóxico e produz impactos socioambientais}

A introdução do cultivo de espécies transgênicas no Brasil se deu pela política do fato consumado e ao arrepio da lei. Sabe-se que a transgenia trouxe mais dependência econômica, interferência cultural, insegurança alimentar e poluição genética. Esses são alguns dos impactos registrados por pesquisadores, povos indígenas, agricultores, representantes do Ministério do Meio Ambiente (MMA) e por organizações não governamentais (ONGs) ambientalistas.

Segundo Rubens Nodari, a tecnologia de transgenia na agricultura exerce impactos sociais, econômicos e culturais. Nesse tipo de tecnologia são inseridos genes que dependem de um produto químico para voltar a ter funcionalidade. Nessa situação, os produtores serão obrigados a pagar royalties a cada compra de semente, o que aumentará os custos da produção. Além disso, pode haver disseminação de sementes geneticamente modificadas para outras plantações, devido à polinização natural (NODARI; GUERRA, 2001).

O conhecimento de que dispomos sobre os efeitos e riscos dos transgênicos ainda requer maiores investimentos em pesquisa. A soja foi lançada nos Estados Unidos em 1996, tendo sido conduzidos apenas estudos de segurança alimentar de curta duração; não se conhece, por exemplo, seu efeito a longo prazo nos indivíduos, como os impactos sobre a reprodução. Os estudos apresentados pelas empresas são mínimos e de curta duração, com número reduzido de características avaliadas. A soja foi avaliada sem glifosato, o que impede a avaliação de efeitos colaterais. Com o milho ocorreu a mesma coisa. $\mathrm{O}$ milho Bt tem dentro dele uma toxina mortal para alguns tipos de insetos, mas sobre a alimentação humana pouco se conhece. É verdade que não temos informa- 
ção suficiente sobre riscos dimensionados, mas também não sabemos se os riscos não existem, até porque isso não foi pesquisado suficientemente. O que podemos assumir de fato é que conhecemos muito pouco sobre o assunto e que é preciso investir mais recursos na pesquisa sobre os impactos dessa tecnologia (NODARI; GUERRA, 2001).

Somente em 2003 foi publicado o primeiro grande estudo de longa duração feito na Inglaterra, que começou em 1999. No estudo, foi analisado o impacto na biodiversidade do cultivo de três espécies - milho, beterraba e canola. No caso da beterraba e da canola, os sistemas transgênicos causavam impacto na biodiversidade maior do que o convencional. A Inglaterra fez sessenta estações experimentais, cobrindo todo o país. Infelizmente, o Brasil, sem essas estações experimentais para realizar estudos de impacto ambiental e de segurança alimentar, tem tomado a decisão de liberar transgênicos (NODARI; GUERRA, 2001).

No Brasil são concomitantes o uso de agrotóxicos e o cultivo de plantas transgênicas. Somos, desde 2010, os campeões mundiais no uso de agrotóxicos, com uma média de mais de cinco quilos para cada brasileiro por ano. Esses dois crescimentos estão relacionados.

Conforme Nodari (2007), enquanto em 2001, no Brasil, se usou o equivalente a 2,7 $\mathrm{kg}$ de agrotóxicos por hectare cultivado, em 2010, foram cerca de $5 \mathrm{~kg}$. Houve um crescimento, no período, da área cultivada com soja e milho transgênicos. A relação entre o cultivo de transgênicos e o aumento do uso de agrotóxicos é notória, uma vez que várias plantas geneticamente modificadas aprovadas para comercialização no Brasil sofreram alteração para receber agrotóxicos.

Nos EUA, os agricultores de algodão, soja e milho já se deparam com outro problema. Nessas culturas, a maior parte dos produtores recorre a sementes geneticamente modificadas, dotadas de um gene que lhes confere resistência ao glifosato, o qual foi desenvolvido originalmente pela Monsanto sob o nome comercial de Roundup. Em 1994 foram aplicadas no EUA cerca de 3,6 mil toneladas de glifosato, e em 2005 esse número saltou para quase 54 mil toneladas. O surgimento de resistência aos herbicidas em uso tem induzido também o maior consumo de outros agrotóxicos nesse país.

Augusto (2012), pesquisadora que foi membro titular da Comissão Nacional de Biossegurança no período de 2005 a 2006, corrobora as afirmações de Nodari ao observar que as plantas transgênicas resistentes aos herbicidas aumentam o grau de dependência dos agricultores aos agrotóxicos. A venda de sementes transgênicas é casada com a dos agrotóxicos, produzidos, em geral, pelas mesmas indústrias.

Mesmo com o uso intensivo do glifosato, já surgiram pragas que apresentam algum grau de resistência a esse herbicida. Os agricultores estão sendo obrigados a elevar a quantidade desse veneno e até requerendo outros tipos de agrotóxicos.

A trajetória que levou à imbricação entre transgênicos e agrotóxicos é o resultado do modelo tecnológico hegemônico que considera o agrotóxico o único caminho para aumentar a produtividade agrícola. 
Outro fenômeno a observar é que anteriormente a produção de sementes e a de agrotóxicos configuravam setores distintos. Atualmente, meia dúzia de empresas que domina o mercado de agrotóxicos domina também a produção de sementes geneticamente modificadas.

\section{É preciso desconstruir os mitos do agronegócio}

É possível legitimar esse modelo de desenvolvimento no campo sem a força de um discurso poderoso que desenhe no imaginário dos diferentes segmentos sociais a promessa de progresso e desenvolvimento? Compreender esse processo exige olhar cuidadosamente para as formas de dominação simbólica que o sustentam. Os mecanismos que atuam para garantir a reprodução de uma ordem social injusta, promotora da desigualdade e da degradação socioambiental são mais complexos do que poderia propor uma abordagem que contemplasse apenas as relações materiais de produção e reprodução do capital (RIGOTTO et al., 2012). Segundo Thompson (2009), para entender as relações de dominação simbólica é preciso analisar o modo como palavras e imagens - compreendidas aqui como construções discursivas - são capazes de sustentar e reproduzir uma ordem social opressora e dificultar o caminho para transformações sociais.

No cotidiano do trabalho, das lutas e das tensões sociais presentes no território, evidenciam-se as contradições do modelo de desenvolvimento que se reproduz atravessado por discursos dissonantes. De um lado a grande promessa, nunca cumprida, às populações locais, de uma vida melhor. De outro, a realidade vivida pelas populações que pagam cotidianamente o preço da busca interminável pelo progresso. Bourdieu nos provoca sobre a importância de enveredarmos pelo campo da análise do poder simbólico

como o poder de constituir o dado pela enunciação, de fazer ver e fazer crer, de confirmar ou de transformar a visão do mundo e, deste modo, a ação sobre o mundo, portanto o mundo; poder quase mágico que permite o equivalente daquilo que é obtido pela força (física ou econômica), graças ao efeito específico de mobilização, só se exerce se for re conhecido, quer dizer, ignorado como arbitrário (BOURDIEU, 2007, p. 14, grifo do original).

Os modos de vida no universo da produção camponesa e familiar passam a ser descritos como arcaicos, e vários mitos vão sendo construídos e replicados para justificar as diversas intervenções ocasionadas pelo modelo agrícola conservador que, mesmo carregando as mais atrasadas práticas, se reveste de "moderno" em seu discurso.

Barthes (2001) adverte que o processo de mitificação consiste em simplificar o mundo naturalizando-o; em outras palavras, a função do mito é subtrair das coisas sua historicidade, de modo a torná-las aparentemente naturais. Essa "captura" da história 
das coisas promovida pelo mito mostra-se útil para a legitimação do discurso desenvolvimentista.

Nesse contexto, torna-se importante relatar o processo vivido pelas populações locais como uma tentativa de devolver a historicidade das coisas e desnaturalizar os significados dados. Tomaremos como exemplos as reflexões produzidas por Rigotto e colaboradores (2012) em pesquisa realizada na Chapada do Apodi, no estado do Ceará.

Mito 1: Não existia vida na Chapada do Apodi antes do agronegócio chegar.

Mito 2: $\mathrm{O}$ agronegócio é moderno e traz o progresso para nós: gera emprego e renda, produz alimentos para acabar com a fome no Brasil e potencializa a riqueza do país.

Mito 3: É possível usar venenos com toda segurança. Os pequenos agricultores é que são o problema! Nem usam os equipamentos de proteção. O efeito do veneno é só no dia em que se pulveriza.

Mito 4: O agronegócio se preocupa com o meio ambiente.

Mito 5: O agronegócio promove o desenvolvimento local.

Mito 6: Não há problemas com o uso de agrotóxicos, porque "as autoridades estão cuidando da gente".

Mito 7: Não existe outra forma de produzir que não seja a do agronegócio.

O primeiro passo a ser dado na análise desses mitos é desvelar sua complexidade e revelar que na Chapada do Apodi existiam há séculos modos de viver e produzir próprios, que há na região formas agroecológicas de produção, que o Estado está imbricado com a reprodução do capital, que os pequenos agricultores também são vítimas do discurso da Revolução Verde, da precarização das relações de trabalho e dos agravos à saúde dos/as trabalhadores/as, dos graves impactos ambientais etc.

No exercício de contar e recontar a história das coisas, articulando a experiência daqueles que fazem o território com os elementos trazidos pela pesquisa e com a força de mobilização dos movimentos sociais, é que se tornou possível vislumbrar a construção de novas "falas" sobre a realidade. Como propôs Barthes (2001, p. 178), "é isso que devemos procurar: uma reconciliação entre o real e os homens, a descrição e a explicação, o objeto e o saber". 
PARTE 2

SAÚDE, AMBIENTE

E SUSTENTABILIDADE

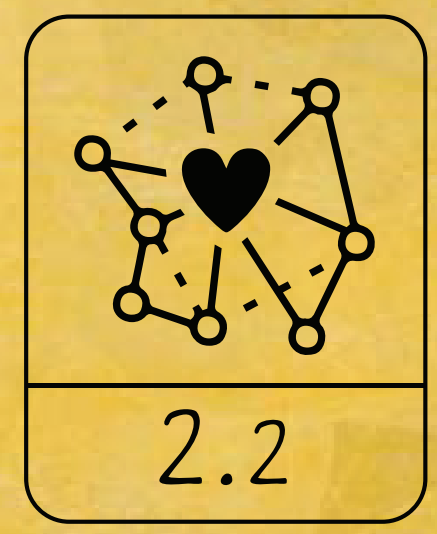

OS POVOS DO CAMPO

E DAS FLORESTAS

VULNERABILIZADOS

PELO AGRONEGÓCIO

dossiêABRASCO
De acordo com os censos demográficos realizados pelo Instituto Brasileiro de Geografia e Estatística (IBGE), em 1950 a população brasileira era de 51.944.397 habitantes e em 2010 foram contados 190.732.694 brasileiros, o que representa um crescimento de $267,2 \%$ em sessenta anos. Em 1940 o censo brasileiro passou a diferenciar população presente e residente no domicílio, o que permite distinguir, desde então, a população considerada urbana e a considerada rural com base na situação do domicílio, "definido conforme a legislação municipal vigente por ocasião da realização do último Censo Demográfico" (IBGE, 2010).

Como consequência do processo de industrialização e realização de grandes obras principalmente a partir da década de 1950 e da modernização da agricultura no Brasil a partir da década de 1960, a população brasileira deixou de ser predominantemente rural nas décadas de 60 e 70. Mesmo assim, nesse período a população rural apresentou crescimento, chegando em 1970 a pouco mais de 41 milhões de habitantes e regredindo progressivamente a partir dessa data para chegar a pouco menos de trinta milhões de habitantes em 2010 (15,65\% da população total), uma diminuição de $29,3 \%$ em quarenta anos (figura 2.2). 
Figura 2.2 - Série histórica da distribuição da população brasileira, por situação do domicílio, entre 1950 e 2010

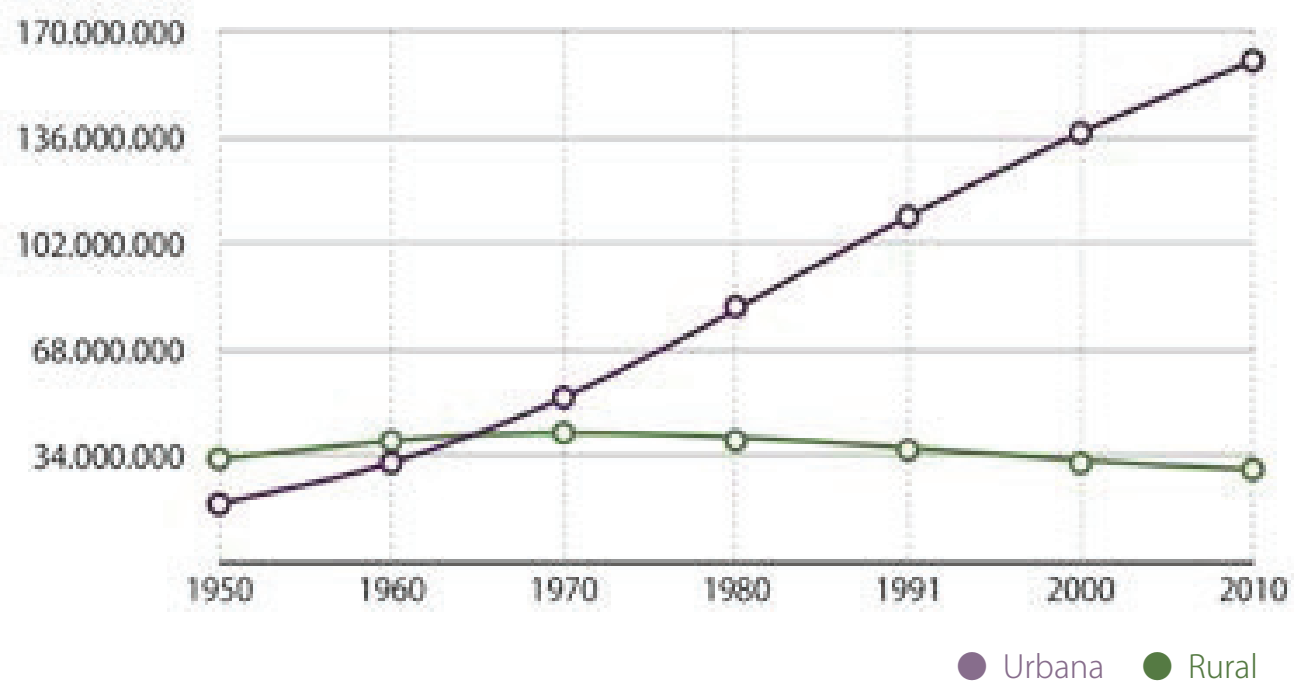

Fonte: IBGE, Censo Demográfico 1950/2010. Até 1991, dados extraídos de Estatísticas do Século XX, Rio de Janeiro : IBGE, 2007 no Anuário Estatístico do Brasil,1993, vol. 53, 1993.

A modernização da agricultura no Brasil aprofundou a concentração de terras, levando tanto à migração de milhares de pequenos proprietários, parceiros, arrendatários e colonos para áreas de expansão da fronteira agrícola, nas regiões Centro-Oeste e Norte, quanto ao êxodo rural para os centros urbanos mais industrializados. Assim, o incremento do pacote tecnológico da Revolução Verde resultou no agravamento de diversos problemas sociais e ambientais, que a história do desenvolvimento da agricultura no país perpetuava, assumindo a forma de modernização conservadora (HESPANHOL, 2008b).

A mecanização da produção agrícola não alcançou todas as fases dos ciclos produtivos. Dessa forma, também como consequência desse processo, cresceu o contingente de trabalhadores rurais assalariados temporários no campo. Esses trabalhadores, que passam boa parte do ano desempregados, e os trabalhadores rurais que migraram para as cidades mas não conseguiram emprego, passaram a se organizar em movimentos sociais, reivindicando a realização da reforma agrária como forma de lhes garantir acesso à terra (HESPANHOL, 2008b).

A intensificação na realização de grandes obras promovidas pelo Estado brasileiro também tem importância para a manutenção do êxodo rural na última década. Muitas dessas obras são de interesse direto de setores do agronegócio, como aquelas para irrigação na agricultura e para escoar a produção para exportação.

Em 2010 havia no Brasil 5.565 municípios, dos quais 38 (0,7\%) apresentavam população acima de quinhentos mil habitantes. Nessas grandes e megacidades, onde 
viviam $29,28 \%$ dos brasileiros, $99 \%$ da população foram considerados urbana. Isso expressa a importância das maiores cidades brasileiras para a caracterização do país como urbano.

Quando são analisados os dados do censo de 2010 por município, fica mais evidente a importância da população considerada rural no país: em $29 \%$ dos municípios brasileiros a população considerada rural é maior que a população urbana, chegando a $40 \%$ nos municípios com menos de vinte mil habitantes. Vale ressaltar, para efeito de comparação e dimensionamento da importância dessa população em termos quantitativos, que somente Argentina, Colômbia e México, entre os países da América Latina, têm população total superior à população que vive em área rural no Brasil. Isso é extremamente importante, pois estamos tratando de uma imensa população que vive em territórios ameaçados ou sob o impacto direto ou indireto dos agrotóxicos.

Há muitas críticas ao método de classificar e estabelecer distinção entre rural e urbano adotado no Brasil, que privilegia o critério da densidade demográfica. E mesmo outros métodos baseados no critério da densidade demográfica, como o da Organização de Cooperação e Desenvolvimento Econômico (OCDE), levariam a índices muito diferentes dos encontrados pelo IBGE: tomando como base o número de 150 habitantes por $\mathrm{km}^{2}$, adotado pela OCDE para caracterizar território rural, teríamos que a população rural brasileira é o dobro daquela divulgada pelo IBGE (VEIGA, 2002). Território rural não pode ser compreendido, simplesmente, como território não urbano, como o que não é cidade. Assim, a qualificação do que é rural e urbano se coloca como um desafio complexo na atualidade; alguns teóricos questionam: será o rural do Brasil de 1940 o mesmo rural brasileiro do século XXI? Que critérios permitem distinguir campo e cidade, urbano e rural, atualmente? (ENDLICH, 2006).

Para Endlich (2006), os limites entre essas duas dimensões, rural e urbano, evidenciados por uma série de estudos sobre pequenas cidades, revelaram-se uma questão mais complexa. Para alguns autores, a ocupação econômica da população deve ser adotada como critério de distinção, ou seja, há indicações de que, em pequenas cidades, pessoas que se dedicam a atividades primárias podem residir em áreas consideradas urbanas com base na metodologia do IBGE. De acordo com o último censo realizado, dos 5.565 municípios brasileiros, 3.915 (70,35\%) tinham população inferior a vinte mil habitantes (IBGE, 2010).

Outra crítica importante à metodologia que adota o local de residência como critério de classificação diz respeito aos trabalhadores que migram durante o dia para trabalhar: os trabalhadores temporários, ou boias-frias, que segundo a Pesquisa Nacional por Amostra de Domicílios (Pnad) de 2008 representavam 43\% do total de empregados ocupados no campo, são considerados como população urbana. A alta taxa de participação dos temporários sintetiza algumas das características ainda dominantes na área rural: "sazonalidade das ocupações, relações de trabalho altamente instáveis, baixos salários, trabalho braçal e extenuante e péssimas condições de trabalho" (IPEA, 2010, p. 18). 
Os trabalhadores temporários apresentaram um rendimento médio mensal de 344 reais $(52,92 \%$ com renda mensal média de até meio salário mínimo) e $84,28 \%$ não tinham carteira de trabalho assinada (IPEA, 2010). Esse é um grupo populacional importante em termos de exposição aos agrotóxicos, pois atuam nas cadeias produtivas do agronegócio em situação de grande vulnerabilidade socioambiental. Apresentamos a seguir dois estudos em que se avaliaram os níveis de condições de vida desses trabalhadores rurais.

Estudo que avaliou as condições de saúde de famílias de boias-frias residentes em bairro da periferia de Unaí (MG), demonstrou que a oferta de trabalho se limitava a, em média, apenas seis meses ao ano, de forma inconstante, o que fazia com que as famílias tivessem renda variável e baixa; as famílias dos boias-frias apresentavam alto índice de insegurança alimentar (39,5\% das famílias enfrentaram falta de comida nos últimos três meses, tendo como referência a data de realização da pesquisa); os trabalhadores temporários sofriam com a exposição aos agrotóxicos e apresentavam baixo nível de organização política. Além disso, para esses trabalhadores rurais, entre o que havia de pior no trabalho estavam a hora de acordar $(44,52 \%)$, o deslocamento $(19,5 \%)$ e a "exploração" (14,3\%), além dos danos difusos relacionados com a comida, os danos à saúde e o cansaço.

Essas condições chegavam a situações extremas. Os relatos incluem até quatro horas de tempo gasto para chegar ao local de trabalho diariamente, fazendo que muitos iniciassem seu deslocamento no início da madrugada Os trabalhadores chegavam a viajar mais de $130 \mathrm{~km}$ para as fazendas onde vão trabalhar, com tempo de deslocamento médio de três horas (CARNEIRO, 2007, p. 81).

A produção de cana-de-açúcar é uma das monoculturas que mais emprega trabalhadores temporários nos estados onde se concentra sua produção. A expansão da área plantada desse cultivo aumenta a demanda por trabalhadores temporários. Estudo sobre as condições de trabalho dos cortadores de cana-de-açúcar no estado de São Paulo concluiu que os processos de produção e de trabalho vigentes no complexo agroindustrial canavieiro exigem que os trabalhadores aumentem o esforço despendido no trabalho. O esforço é tamanho que o dispêndio de energia resulta em morte dos trabalhadores ou em perda precoce de capacidade de trabalho: para cortar uma média de 12 toneladas de cana por dia, o trabalhador caminha 8.800 metros, carrega 12 toneladas de cana em montes de 15 quilos em 800 trajetos e 800 flexões de pernas, desfere 133.332 golpes de facão para cortar a cana, flexionando o corpo 36.630 vezes para golpear, o que leva a uma perda diária, em média, de 8 litros de água sob os efeitos de sol forte, poeira e fuligem expelida pela cana queimada (ALVES, 2006).

Os(as) trabalhadores(as) rurais que vivem em pequenas propriedades de terras formam outro grupo importante das populações que vivem em áreas consideradas rurais 
no Brasil. A agricultura familiar ${ }^{6}$, apesar de ocupar apenas $24,3 \%$ da área total dos estabelecimentos agropecuários, é responsável por $74,4 \%$ das pessoas ocupadas no campo, com uma taxa de ocupação média de 15,3 pessoas por cem hectares, ao passo que a agricultura não familiar (agronegócio) ocupa 1,7 pessoa por cem hectares. E responde pela produção nacional de $87 \%$ da mandioca, $70 \%$ do feijão, $46 \%$ do milho, $38 \%$ do café, $34 \%$ do arroz, $59 \%$ dos suínos, $58 \%$ do leite e $50 \%$ das aves. Com isso, contribui com a geração de $38 \%$ do valor bruto da produção (BRASIL. MDA, 2009).

Esses dados se mostram impressionantes quando cotejados com outras duas informações importantes sobre o papel do Estado na indução da produção agrícola: 1) somente em 1996, com a criação do Programa Nacional de Fortalecimento da Agricultura Familiar (Pronaf), os pequenos produtores passaram a ter acesso a crédito oficial (HESPANHOL, 2008a); 2) o Plano Safra tem destinado, atualmente, entre $80 \mathrm{e}$ $90 \%$ do orçamento para o financiamento do agronegócio, ficando a parcela restante para a agricultura familiar.

As populações rurais vivem em situação precária e com limitações de acesso às políticas públicas. Segundo o Censo Agropecuário 2006 (IBGE, 2006), 39\% dos produtores rurais nunca frequentaram a escola e outros $43 \%$ responderam que não haviam completado o ensino fundamental. E havia mais de um milhão de menores de 14 anos de idade trabalhando na agropecuária. A Pnad de 2004 revela dados da situação de segurança alimentar no Brasil por domicílio. Aproximadamente 35\% dos domicílios particulares do país enfrentam algum grau de insegurança alimentar, sendo a população rural a que mais sofre com a carência alimentar: $43,45 \%$ dos domicílios particulares rurais enfrentam a situação de insegurança alimentar, dos quais $40 \%$ com insegurança alimentar de grau leve, $39 \%$ de grau moderado e $21 \%$ de grau grave (IBGE, 2004).

Ainda com base em dados do IBGE, apresentamos dois indicadores relacionados ao acesso às ações e serviços de saúde, comparando a população urbana com a rural: acesso a consultas médicas e odontológicas e cobertura de componentes do saneamento básico. Apesar da melhoria do acesso à assistência em saúde no período compreendido entre 2003 e 2008 , nesse ano $20 \%$ da população rural informaram nunca terem sido atendidos por um dentista e $30 \%$ das crianças menores de 4 anos não haviam realizado consulta médica no último ano. Para a população urbana, também em 2008, esses indicadores são de 10\% e 17,3\%, respectivamente (quadro 2.1 ).

\footnotetext{
${ }^{6}$ A Lei n. 11.326, de 24 de julho de 2006, define o que é agricultura familiar com base nos seguintes critérios: a área do estabelecimento não pode exceder quatro módulos fiscais; a mão de obra deve ser predominantemente da própria família; a renda deve se originar predominantemente das atividades da propriedade e o estabelecimento tem que ser dirigido pela própria família.
} 
Quadro 2.1 - Acesso a consultas médicas e odontológicas no Brasil, em percentual da população, por situação de domicílio, em 2003 e 2008

\begin{tabular}{|l|c|c|c|c|}
\hline \multirow{2}{*}{ Indicador } & 2003 & 2008 & 2003 & 2008 \\
\cline { 2 - 5 } & & & & \\
\hline $\begin{array}{l}\text { Realizou ao menos uma consulta } \\
\text { médica no último ano }\end{array}$ & $64,90 \%$ & $69,30 \%$ & $51,60 \%$ & $59,50 \%$ \\
\hline $\begin{array}{l}\text { Criança (<4 anos) que realizou ao menos } \\
\text { uma consulta médica no último ano }\end{array}$ & $80,70 \%$ & $82,70 \%$ & $63,90 \%$ & $69,50 \%$ \\
\hline Já foi atendido por um dentista & $86,40 \%$ & $90 \%$ & $72 \%$ & $80 \%$ \\
\hline
\end{tabular}

Fonte: IBGE $(2003,2008)$.

Em relação a componentes do saneamento básico, no ano de 2000, 12,15\% da população rural tinham acesso à coleta de lixo, 11,78\% a esgotamento sanitário e $17,8 \%$ a abastecimento de água. Esses mesmos indicadores para a população urbana eram, respectivamente, $91,13 \%, 70 \%$ e $89,12 \%$. A melhoria do acesso a esses serviços, se comparados os dados dos censos do IBGE de 1991 e 2000, foi maior na população urbana, com exceção do abastecimento de água, apesar das enormes desigualdades de acesso entre essas populações (figura 2.3).

Figura 2.3 - Cobertura de componentes do saneamento básico no Brasil, por situação do domicílio, 1991 e 2000

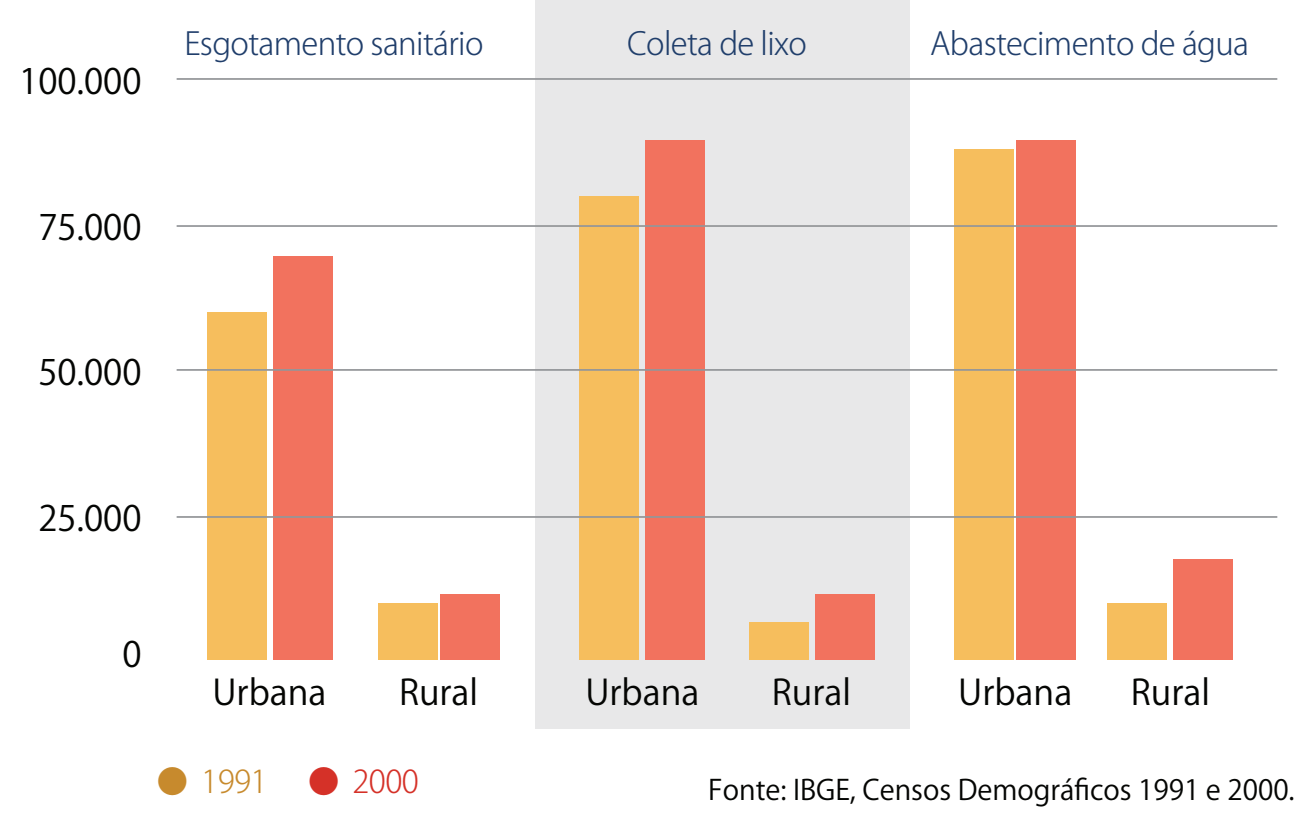


Estudo realizado entre pequenos agricultores demonstrou que nas áreas dos produtores rurais que receberam crédito agrícola do governo federal (Pronaf Crédito Rural) na safra 2000-2001 houve aumento da erosão dos solos e da frequência do uso de pesticidas, o que suscita questões quanto à qualidade da assistência técnica prestada pelo programa de crédito agrícola (MIRANDA et al., 2007). Esse estudo indica que a assistência técnica prestada pelo poder público à agricultura familiar estimulava a utilização de agrotóxicos e demonstra que o modelo de desenvolvimento do campo continuava envolvendo parte das pequenas propriedades no plantio de monoculturas com a utilização de agrotóxicos, processo resultante da modernização da agricultura nas décadas de 1960 e 1970. Segundo Carneiro e Almeida (2007, p. 22): "esta estrutura produtiva [da agricultura familiar], assim como a da grande propriedade, estão subordinadas ao mesmo modelo conservador. Este tem se imposto historicamente e principalmente por meio das políticas de crédito rural, da assistência técnica e da pesquisa".

O Censo Agropecuário de 2006 revela acesso limitado à assistência técnica: somente $22 \%$ dos estabelecimentos agropecuários, que ocupavam $46 \%$ das terras, recebiam algum tipo de orientação técnica. Esses dados revelam ainda mais da complexidade e das injustiças socioambientais da questão agrária no Brasil, pois indicam que as populações mais pobres, que vivem nas menores propriedades, têm graves limitações de acesso a políticas sociais e sofrem com insegurança alimentar, também têm dificuldade em acessar a assistência técnica; indicam também que a assistência técnica pode induzir ao uso de agrotóxicos.

Há ainda a assistência técnica que chega até os pequenos produtores prestada por grandes empresas do agronegócio. No Brasil há muitas pequenas propriedades produzindo no sistema de integração com grandes empresas, como na produção de fumo, aves, suínos e celulose. Trata-se de mais uma forma de territorialização do modelo de desenvolvimento do agronegócio, nesse caso em territórios da agricultura familiar camponesa. $\mathrm{Na}$ expansão do agronegócio se desterritorializam formas de produzir a vida forjadas em diferentes comunidades tradicionais ou camponesas. Não se substitui somente o que se produz ou a forma de produzir, mas a relação da humanidade com a natureza; impõe-se, assim, um modelo civilizatório.

É preciso olhar com mais atenção para a força dos dados sobre a produção de alimentos e as oportunidades de trabalho na agricultura familiar. Os dados apresentados nesta seção, a partir de estudos e dados disponibilizados, principalmente do IBGE, não expressam a diversidade cultural e de formas de construir a vida dos milhões de brasileiros que resistem no campo e nas florestas: são camponeses, agricultores familiares, povos indígenas, comunidades quilombolas, atingidos por barragens, ribeirinhos, caiçaras, faxinais, fundo de pasto, assentados da reforma agrária, meeiros, arrendatários, quebradeiras de coco, seringueiros, artesãos, caboclos, comunidades de terreiros, entre outros povos e comunidades tradicionais. 
Uma diferença fundamental entre agronegócio e agricultura está presente nos nomes: no agronegócio não há cultura, pois não há povo, a relação homem-natureza é mediada pelos valores do mercado, do negócio. A sociodiversidade cultural presente no campo e na floresta do Brasil se expressa nos povos que produzem alimento, vivem na terra e da terra, das águas e da floresta. 
PARTE 2

SAÚDE, AMBIENTE

E SUSTENTABILIDADE

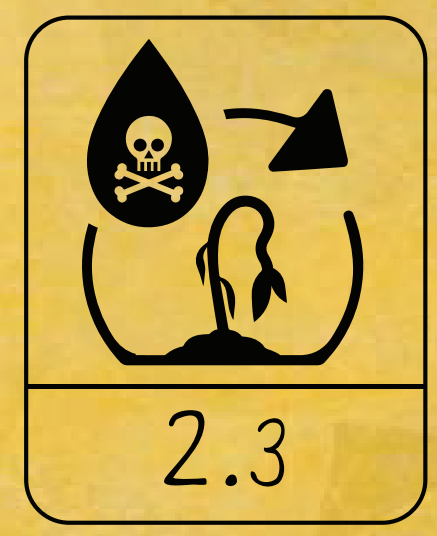

AGROTÓXICO E SAÚDE AMBIENTAL
O Brasil é o maior consumidor mundial de agrotóxicos, dado estimado pelo volume comercializado no país. Os trabalhadores expostos a esses produtos são numerosos, sendo as intoxicações agudas a face mais visível do seu impacto na saúde (FARIA; FASSA; FACCHINI, 2007).

A utilização dos agrotóxicos no Brasil tem trazido sérias consequências, tanto para o meio ambiente como para a saúde de populações como a do trabalhador, especialmente o camponês e suas famílias. Essas consequências são, na maioria das vezes, condicionadas pelo contexto e modo de produção químicodependente, pelas relações de trabalho, pela toxicidade dos produtos utilizados como agrotóxicos e de micronutrientes contaminados, pela precariedade dos mecanismos de vigilância da saúde, pelo uso inadequado ou falta de equipamentos de proteção coletiva e individual. Tal situação é agravada pelas precárias condições socioeconômicas e culturais da grande maioria dos trabalhadores rurais, que ampliam sua vulnerabilidade à toxicidade dos agrotóxicos (SILVA et al., 2005; SOBREIRA; ADISSI, 2003).

São inúmeros os casos de contaminação ambiental resultantes da irresponsabilidade de empresas fabricantes e formuladoras de agrotóxicos, bem como do agronegócio, que é grande usuário de venenos. Não raramente populações inteiras são expostas aos riscos da contaminação. Na maioria das vezes as pessoas que adoecem por conta da exposição aos venenos não conseguem comprovar a causa das doenças desenvolvidas, e com isso os responsáveis pela contaminação escapam de arcar com os custos de tratamentos de saúde ou de medidas para mitigar os efeitos da contaminação ambiental. 
O Brasil carece de dados sobre o número de intoxicações por não contar ainda com um sistema de registro eficiente, capaz de identificar especificamente os agrotóxicos envolvidos nos casos de intoxicações agudas e crônicas. Vários sistemas oficiais registram intoxicações por agrotóxicos no país, mas nenhum deles tem respondido adequadamente como instrumento de vigilância deste tipo de agravo (FARIA; FASSA; FACCHINI, 2007). O Ministério da Saúde (MS) estima que, no Brasil, anualmente, existam mais de quatrocentas mil pessoas contaminadas por agrotóxicos, com cerca de quatro mil mortes por ano (MOREIRA; JACOB; PERES, 2002).

Intoxicações envolvendo agrotóxicos no Brasil foram analisadas por Benatto (2002) com base em dados do Sistema Nacional de Agravos Notificados (Sinan). Segundo esse autor, foi registrado no período de 1996 a 2000 um total de 5.654 casos suspeitos de intoxicação, com 2.931 casos confirmados (51,43\%). O número de óbitos registrado foi de 227, correspondendo a uma letalidade de 7,73\% no período. As intoxicações se concentraram em indivíduos do sexo masculino entre 15 e 49 anos, sendo confirmadas pelo critério clínico-epidemiológico em $60 \%$ dos casos; $61,74 \%$ dos casos de intoxicação receberam atendimento hospitalar; $29,46 \%$ atendimento ambulatorial; $7,03 \%$ atendimento domiciliar e $1,77 \%$ dos casos não receberam nenhum atendimento. Os acidentes de trabalho representaram 53,5\% das circunstâncias de intoxicação, seguidos pelas tentativas de suicídio $(28,2 \%)$ e por intoxicações acidentais $(12,9 \%)$. Dentre os 128 princípios ativos envolvidos nas intoxicações o glifosato, o paraquat e o metamidofós foram os agentes tóxicos mais incriminados, correspondendo a $26,2 \%$ do total. Os registros desses três agrotóxicos estão sendo reavaliados pela Anvisa, e o metamidofós passou a ser proibido no Brasil no ano de 2011.

No Brasil, o Sistema Nacional de Informações Tóxico-Farmacológicas (Sinitox) sistema de informações do MS e da Anvisa, disponibilizado pela Fundação Oswaldo Cruz (Fiocruz) desde 1996 e uma das fontes de informação sobre notificação de casos de intoxicações por agentes químicos - registrou, no ano de 2009, 5.253 casos de intoxicação por agrotóxicos de uso agrícola, 2.868 casos por agrotóxicos de uso doméstico, 1.014 casos por produtos veterinários e 2.506 casos por raticidas, com um total de 188 óbitos por estes quatro tipos de intoxicação. Os agrotóxicos de uso agrícola responderam por $41,8 \%$ do total. Deve-se ressaltar a grande ocorrência, no Brasil, de sub-registro das intoxicações por agrotóxicos. Esta é uma das grandes vulnerabilidades institucionais do país, entre outras relacionadas ao controle e monitoramento do uso de agrotóxicos em todo o território nacional, e um aspecto a ser levado em consideração nos processos de registro e reavaliação desses produtos técnicos.

Os dados mais recentes disponibilizados pelo Sinan-MS indicam que as intoxicações agudas por agrotóxicos no país já ocupam a segunda posição entre as intoxicações exógenas notificadas. O número de casos notificados pelo Sinan relacionados à intoxicação por agrotóxicos aumentou 67,3\% entre 2007 (2.071 casos) e 2011 (3.466 casos) (OMS/OPAS, 2012). 
A exposição de crianças pode diferir da exposição de adultos, pois a fisiologia e o comportamento único da criança podem influenciar na extensão da exposição. As crianças são particularmente sensíveis aos agrotóxicos em decorrência de sua alta permeabilidade intestinal e da imaturidade do seu sistema de detoxificação (ATSDR, 2000). Essas diferenças devem ser levadas em consideração quando se avaliam riscos dos agrotóxicos.

O trabalho agrícola é uma das ocupações mais perigosas da atualidade. Dentre os vários riscos ocupacionais, destacam-se os agrotóxicos, que estão relacionados a intoxicações agudas, doenças crônicas, problemas reprodutivos e danos ambientais (ILO/WHO, 2005).

Embora também tenha crescido nos últimos anos, a pesquisa brasileira sobre o impacto do uso de agrotóxicos na saúde humana ainda é insuficiente no tocante à extensão da carga química de exposição ocupacional e à dimensão dos danos à saúde decorrentes do uso intensivo desses herbicidas. Um dos problemas é a falta de informações sobre o consumo de agrotóxicos e a insuficiência dos dados sobre intoxicações por esses produtos (FARIA; FASSA; FACCHINI, 2007).

Medidas mitigadoras dos efeitos da utilização de agrotóxicos incluem, de modo geral: limitação do uso de substâncias altamente tóxicas; regulação do mercado e da propaganda; desenvolvimento de produtos e tecnologias menos perigosas; fiscalização da produção nas indústrias; inspeção dos produtos nas lojas de venda e do modo de uso nos locais de utilização; monitoramento da população mais exposta e mais vulnerável; atenção à saúde e amparo social; alfabetização; conscientização e capacitação dos trabalhadores rurais, entre outras (CASTRO; CONFALONIERI, 2005).

Pesquisas populacionais têm demonstrado a gravidade das situações em que os agrotóxicos são utilizados no campo. Nas cidades de Antônio Prado e Ipê (RS), por exemplo, $2 \%$ dos trabalhadores rurais relataram intoxicações ocupacionais por agrotóxicos no ano anterior. Apesar disso, nenhum desses casos havia sido notificado ao Centro de Informações Toxicológicas (CIT) do Rio Grande do Sul (FARIA; FASSA; FACCHINI, 2007). Dados não publicados de outro estudo confirmam situação semelhante em Bento Gonçalves (RS). Os autores identificaram 18 pessoas que relataram intoxicação aguda, sendo que nenhum desses casos foi notificado ao CIT/Sinitox (FARIA; ROSA; FACCHINI, 2009).

O acesso restrito aos serviços de saúde e a meios diagnósticos ainda limita os cuidados com a saúde e inibe a procura por atendimento médico em casos de intoxicação. Quando tais serviços e meios são procurados, muitas vezes o caso não é devidamente registrado pelos profissionais da saúde. Medidas preventivas e de proteção à saúde também são pouco usuais por parte dos empregadores nas áreas de trabalho agrícola.

As equipes da rede de saúde têm, com frequência, dificuldade em realizar um diagnóstico preciso das intoxicações por agrotóxicos, o que prejudica não só o tratamento, mas também a notificação da ocorrência (SCHMIDT; GODINHO, 2006). Infelizmente, 
no Brasil os profissionais da saúde tanto da rede básica de saúde como da rede de média complexidade não foram devidamente treinados para fazer o diagnóstico de intoxicação e investigações das exposições humanas e de surtos de intoxicação. Outras vulnerabilidades existem, como, por exemplo, as de ordem social: é alta a frequência de trabalhadores rurais desprovidos de seguridade social e da escolaridade mínima necessária para lidar com substâncias perigosas. A grave situação social coloca mulheres e crianças em situações de risco também pelas históricas desigualdades sociais observadas nas áreas agrícolas.

$\mathrm{Na}$ África do Sul, dados da rotina de notificações foram comparados com dados de uma região onde foi realizado um projeto de intervenção para melhorar a abordagem e a notificação das intoxicações. Em cinco anos, o coeficiente de intoxicações na área do estudo passou de 4,2/100.000 para 40,5/ 100.000. Além disso, foi evidenciado que o sub-registro era mais importante nos casos ocupacionais (LONDON; BAILIE, 2001).

$\mathrm{Na}$ prática, só se registram os casos agudos e mais graves. Mesmo para os casos agudos, o sub-registro é muito grande e os casos crônicos não são captados por nenhum dos sistemas de informação (FARIA; FASSA; FACCHINI, 2007).

A Anvisa desenvolveu outro Sistema de Notificações em Vigilância Sanitária (Notivisa), um sistema informatizado que visa à reformulação do processo de recebimento e tratamento de notificações de eventos adversos e queixas técnicas relacionadas a produtos sob vigilância sanitária, inclusive agrotóxicos. Embora o sistema seja recente, já existem registros de casos de intoxicações ocupacionais relacionadas a diversos agrotóxicos perfeitamente identificados, revelando a ponta de um iceberg.

As publicações mais recentes da Organização Internacional do Trabalho e da Organização Mundial da Saúde (OMS) estimam que, entre trabalhadores de países em desenvolvimento, os agrotóxicos causam anualmente setenta mil intoxicações agudas e crônicas que evoluem para óbito, e pelo menos sete milhões de casos doenças agudas e crônicas não fatais.

Embora os equipamentos de proteção individual (EPIs) não sejam eficientes para proteger efetivamente os trabalhadores do desenvolvimento de intoxicações crônicas, deixar de utilizá-los ou utilizá-los de forma inadequada contribui para o elevado número de acidentes com agrotóxicos. Os motivos alegados para não utilizar os equipamentos de proteção são o fato de os patrões não os disponibilizarem, mas também o desconforto e a incerteza quanto à sua eficácia (SCHMIDT; GODINHO, 2006; CASTRO; CONFALONIERI, 2005).

Os trabalhadores rurais no Brasil têm, em geral, baixo nível de escolaridade; muitas vezes utilizam a aplicação intensiva de agrotóxicos como principal medida de controle de pragas; passaram por pouco ou nenhum treinamento para a utilização de agrotóxicos; desconhecem muitas situações de risco e não utilizam equipamentos de proteção coletiva e individual para a manipulação e aplicação dos produtos (SCHMIDT; GODINHO, 2006; CASTRO; CONFALONIERI, 2005). 
Em relação às mortes, dados informados pelo Instituto de Saúde Coletiva da Universidade Federal da Bahia (SANTANA et al., 2012) em março de 2012 indicam a ocorrência no Brasil de 2.052 óbitos por intoxicação por agrotóxico entre 2000 e 2009, sendo que 743 (36,2\%) dos falecidos não dispunham de registro da ocupação e 679 $(51,9 \%)$ eram decorrentes acidentes de trabalho relacionados a agrotóxicos. Assim, segundo essa autora, apenas 38 (5,6\%) dos casos foram registrados na Declaração de Óbito como acidente de trabalho. Destaca-se que $41,8 \%$ dos óbitos (284) ocorreram na região Nordeste, o que sugere um contexto de grave vulnerabilidade socioambiental nessa região.

Estamos falando de um sistema que notificou em 2009 por volta de seis mil casos de intoxicação por agrotóxicos para todo o país. Segundo a OMS, na maioria das situações a subnotificação é muito presente, portanto, estima-se que para cada caso notificado, outros cinquenta não o foram. Isso significa que estão provavelmente ocultos outros trezentos mil casos de intoxicações, que não são identificados por fatores diversos que vão desde a falta de acesso aos serviços de saúde pela população do campo, as dificuldades enfrentadas pelos médicos em identificar esse tipo de intoxicação, a falta de preenchimento adequado das fichas, até o medo dos profissionais da saúde de assumir tal notificação, haja vista o poder dos grandes fazendeiros do agronegócio nesses territórios. Em um estudo da Universidade Federal de Pelotas, no Rio Grande do Sul (FARIA et al., 2000), estima-se em 91,6\% o sub-registro de acidentes de trabalho entre trabalhadores da agricultura. Isso sugere que os dados disponíveis no Sistema Único de Saúde (SUS) ainda apresentam elevado grau de imprecisão, com tendência a elevada subestimação da grave situação atual.

O Estado brasileiro se mostra, assim, forte para financiar o agronegócio e isentar os agrotóxicos de impostos, e, ao mesmo tempo, mínimo quando se trata de proteger a saúde da população e do ambiente dos impactos do atual modelo de produção dominante na agricultura brasileira. Trata-se de um modelo baseado na "Revolução Verde", que de verde só tem o nome (uma de suas principais características foi a quimificação da agricultura).

Estudo realizado por Araújo (1998) em produção de tomate industrial na região do submédio do Vale do Rio São Francisco (PE) mostrou que 11\% das amostras estavam impróprias para consumo.

A soja é a principal cultura consumidora de agrotóxicos no Brasil, tendo sido responsável, em 2006, por 38,5\% do valor total das vendas. Em segundo lugar está a cana-de-açúcar (12,6\%) (FERREIRA; VEGRO; CAMARGO, 2008). Tendo em vista o cenário de crescimento da área plantada dessas duas commodities agrícolas, em especial da soja transgênica, estima-se que o consumo de agrotóxicos continue crescendo. 
Figura 2.4 - Coeficiente de mortalidade por intoxicação (CM/100.000) entre trabalhadores da agropecuária, por sexo. Brasil, 2000-2008

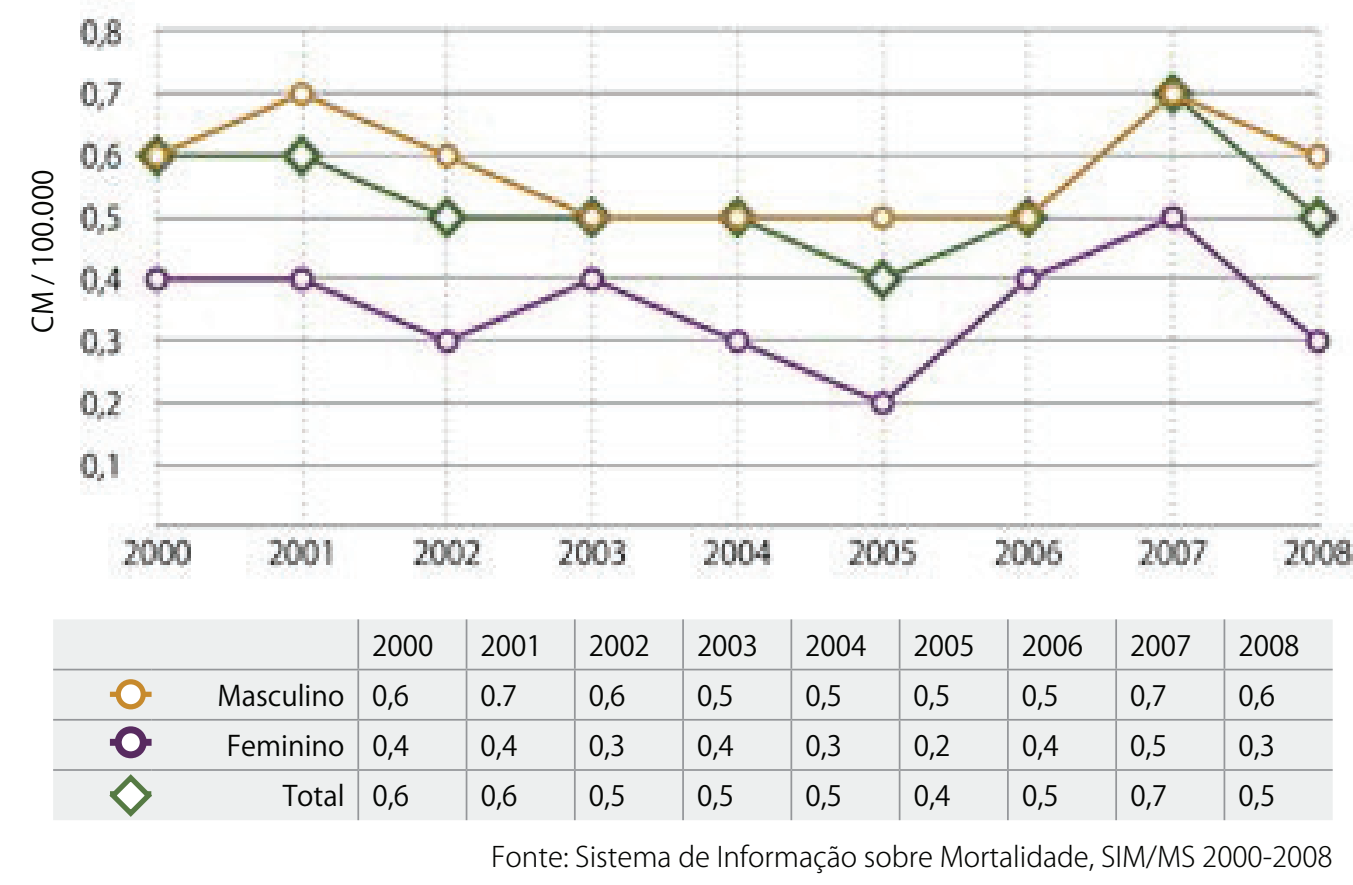

e IBGE, Sistema Contas Nacionais 2000-2008.

Figura 2.5 - Coeficiente de incidência de acidentes de trabalho por intoxicação por agrotóxico em trabalhadores da agropecuária (Cl/1.000). Brasil, 2007-2011

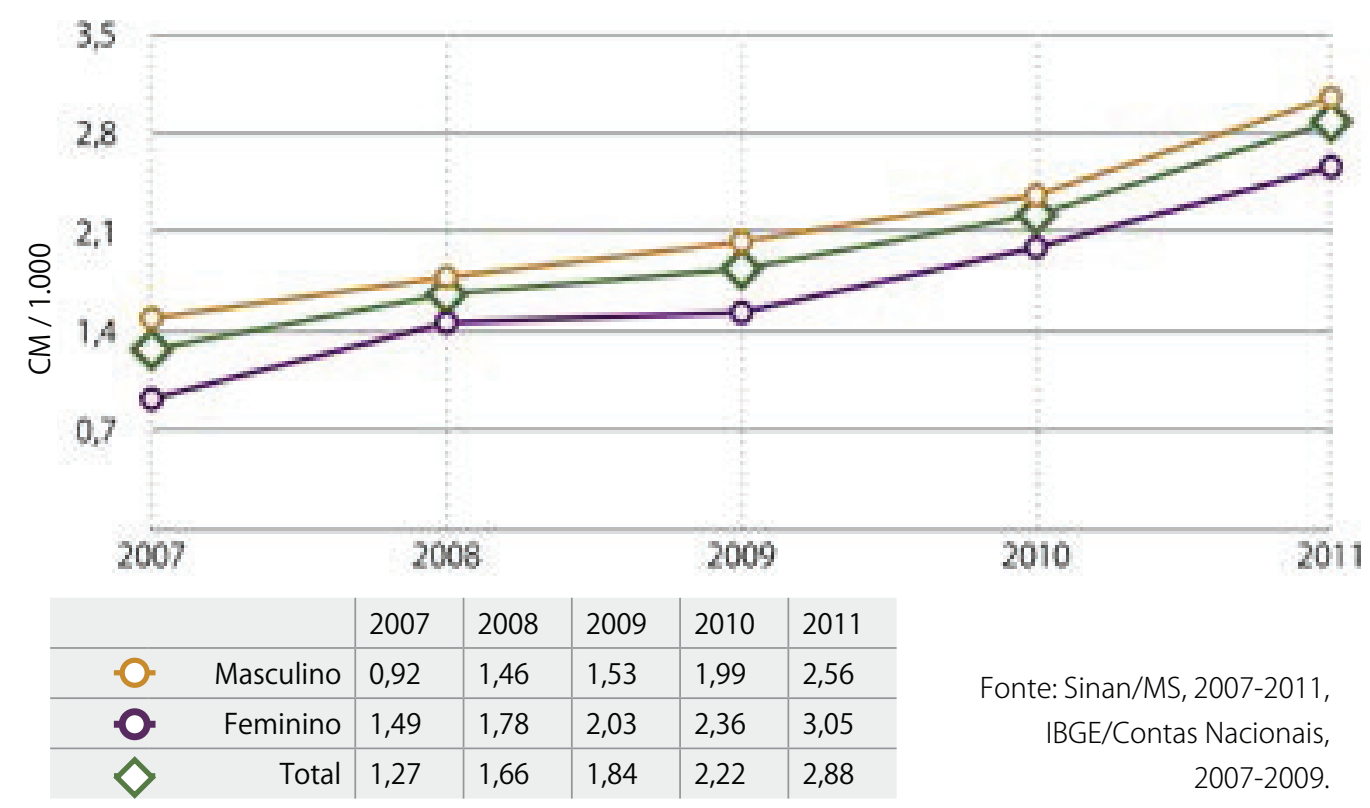


O Programa de Avaliação de Resíduos de Agrotóxicos (PARA) confirma que entre 2008 e 2010 o uso de agrotóxicos não autorizados (NA) e a presença de resíduos acima do limite máximo permitido (LMR) continuam frequentes, sugerindo que medidas mais eficientes devem ser implementadas. O que reforça a necessidade de proceder à reavaliação de uma série dessas substâncias, proposta pela Resolução da Diretoria Colegiada (RDC) n. 10, de 22/02/08, da Anvisa (2008).

O grupo técnico da Fiocruz que elaborou a revisão sistemática de reavaliação dos agrotóxicos, no período 2009 a 2012, possibilitou a utilização das informações que se seguem. Parte delas já foi tornada pública por ocasião da consulta pública sobre alguns dos agrotóxicos constantes da lista de reavaliação; outros dados foram agregados na atualização deste dossiê.

\section{O caso dos organofosforados}

Os organofosforados (OPs), historicamente usados como inseticidas e como agentes químicos de guerras, são de grande importância para a saúde pública, por sua elevada toxicidade.

O metamidofós, a parationa metílica, o fosmete, o forate, o triclorfom, o carbofurano, o monocrotofós, o clorpirifós e o acefato pertencem ao grupo químico dos OPs, e alguns foram incluídos no processo de revisão de seus registros pela Anvisa. Os OPs são inibidores irreversíveis da acetilcolinesterase (AChE) e provocam efeitos tóxicos sobre os diferentes sistemas dos seres vivos a eles expostos (EDWARDS; TCHOUNWOU, 2005), como vimos brevemente na Parte 1 deste dossiê.

Os primeiros compostos organofosforados foram preparados por alquimistas na Idade Média, mas seu estudo sistemático teve início no século XIX, quando, em 1820, Lassaigne esterificou o ácido fosfórico. Vinte e cinco anos mais tarde, uma série de derivados de fosfinas foi preparada por Thinard e colaboradores, e a partir desses trabalhos o progresso da investigação dos compostos de fósforo se acelerou (SANTOS, 2007).

A partir da segunda metade do século XIX, o desenvolvimento desses compostos foi dominado por pesquisadores britânicos e alemães (TOY, 1976; STODDART, 1979). A descoberta, em 1930, das propriedades tóxicas e inse-

Figura 2.6 - Estrutura química geral dos organofosforados (OPs)<smiles>[R]O[R]([R20])([R20])[R]</smiles>
ticidas de alguns compostos de fósforo por Schrader e colaboradores levou à criação de novos compostos organofosforados nas indústrias (STODDART, 1979).

A qualidade inseticida dos OPs foi primeiramente observada na Alemanha durante a Segunda Guerra Mundial, em um estudo sobre gases (sarin, soman e tabun) extremamente tóxicos para o sistema nervoso (ROSATI et al., 1995). 
Os compostos organofosforados foram introduzidos como biocidas na década de 1970, inicialmente apresentados como substitutivos dos organoclorados por serem menos persistentes no ambiente, porém com alta toxicidade (WOODWELL; WURSTER; ISAACSON, 1967; PEAKALL et al., 1975; MURPHY, 1988). Foi também a partir dessa época que aumentou de forma drástica o número de casos de intoxicação por OPs, mesmo em baixas doses (ARAÚJO et al., 2007).

Os OPs são ésteres fosfóricos compostos por um átomo de fósforo pentavalente, derivado do ácido fosfórico, do ácido tiofosfórico ou do ácido ditiofosfórico (BRASIL. MS, 1997). Sua estrutura química está representada na figura 2.6.

O átomo de fósforo da molécula do OP é polarizável e os radicais R1 e R2 são grupos aril ou alquil que se ligam diretamente ao átomo de fósforo, formando fosfinatos, ou através de um átomo de oxigênio ou de enxofre, formando fosfatos e fosforotioatos (HOLLINGWORTH, 1976; CHAMBERS; CARR, 1995; COCKER et al., 2002).

O R1 pode estar diretamente ligado ao átomo de fósforo e o R2 pode estar ligado por um átomo de oxigênio ou de enxofre, formando fosfonatos ou tiofosfonatos. Os fosforamidatos apresentam no mínimo um grupo - $\mathrm{NH} 2$ na molécula. Os grupos amino dos fosforamidatos podem ser: não substituídos, mono ou di-substituídos. Os átomos que podem formar ligação dupla com o fósforo são: oxigênio, enxofre, selênio, cloro, flúor e os cianofosforados, como sarin, soman e tabun (HOLLINGWORTH, 1976; CHAMBERS; CARR, 1995).

Cocker e colaboradores (2002) estudaram a importância das características estruturais dos compostos organofosforados e mostraram que estas estão relacionadas com suas diferentes atividades tóxicas, tais como o tipo de heteroátomo ou grupo funcional ligado ao átomo de fósforo e seu estado de oxidação. Assim, na estrutura geral dos OPs a parte ' $\mathrm{X}$ ' da molécula (ver figura 2.6) possibilita a sua diferenciação em produtos específicos. Os inseticidas OPs são usados frequentemente na forma "thio" $(\mathrm{P}=\mathrm{S})$, que por dessulfuração metabólica oxidativa produz a forma $\mathrm{P}=\mathrm{O}$.

Foi comprovado que a toxicidade elevada para a espécie humana de diversos OPs está relacionada às ligações $\mathrm{P}=\mathrm{O}$ presentes em sua estrutura molecular ou em seus metabolitos. Essa ligação possibilita maior transferência de elétrons do fósforo para o oxigênio, resultando em cargas mais intensas nos dois elementos e, como consequência, em interações mais fortes entre o organofosforado e o centro esterásico da enzima acetilcolinesterase (COCKER et al., 2002).

As implicações dos OPs para a saúde ambiental se devem aos efeitos desses agentes ao longo do tempo e representam um grande risco para a saúde pública, o que torna necessário o monitoramento em águas, solos, ar e alimentos. As transformações no meio ambiente e as alterações no nível bioquímico são as primeiras respostas detectáveis e quantificáveis, constituindo-se em indicadores mais sensíveis porque podem ser detectados com um tempo de exposição mais curto do que o demandado nas observações de efeito nos organismos biológicos. 
Os compostos organofosforados ganharam enorme uso como inseticidas por sua forte atividade biológica acoplada à sua relativa instabilidade na biosfera, que se traduz em uma meia-vida em plantas da ordem de dois a dez dias, em média (SANTOS et al., 2007).

A presença e a persistência dos agrotóxicos no meio ambiente variam em função de diversos condicionantes: eles podem ser encontrados em diferentes compartimentos ambientais por tempos variados. No ar, tal presença e persistência são originárias de procedimentos de aplicação na pulverização em forma de aerossóis. No solo, decorrem do derramamento ou do descarte inadequado, que por percolação podem atingir o lençol freático, e por carreamento das águas de chuva ou pela utilização em campanhas de saúde pública podem atingir as águas superficiais (KOMATZU; VAZ, 2004).

O desequilíbrio ecológico ocasionado pelos agrotóxicos acarreta problemas à própria agricultura, agravando a proliferação de pragas e doenças, com consequente maior uso de produtos e/ou de substâncias com maior toxicidade (PASCHOAL, 1979).

Os principais tipos de interação entre agrotóxicos e meio ambiente se dão por adsorção, absorção, retenção, biodegradação, degradação físico-química, dissolução, precipitação, lixiviação, escoamento superficial, volatilização e sorção (GHISELLI; JARDIM, 2007).

O transporte atmosférico também pode ocorrer por volatilização dos compostos aplicados nos cultivos e pela formação de poeira do solo contaminado (ROCH; COOPER, 1991). O agrotóxico pulverizado pode ser carreado pelos ventos, com maior intensidade no caso daqueles pulverizados por aviões, promovendo a exposição de agricultores locais e de populações distantes do local de aplicação. A volatilização é um dos principais fatores de dissipação do agrotóxico no solo e para a atmosfera, e depende, além da pressão de vapor, das propriedades do solo e do clima (GHISELLI; JARDIM, 2007), ao passo que os decorrentes da aplicação com aeronaves são carreados pelos ventos, inclusive se precipitando sobre as cidades e vilas rurais junto com a água das chuvas, como vimos na Parte 1 deste dossiê.

Durante o período em que permanecem no meio ambiente, os agrotóxicos podem sofrer transformações, isto é, mudanças na sua estrutura molecular. Tais transformações podem ser mediadas pela luz, pela temperatura, por reações químicas (hidrólise, oxidação, descarboxilação) ou por outros agentes biológicos (biodegradação). Quanto maior a quantidade dos agrotóxicos, menor a quantidade de microrganismos e menor será o poder de biodegradação. Essa situação faz aumentar o tempo de persistência do agrotóxico no ambiente (EMBRAPA, 1997; GOSS, 1992).

A temperatura e as culturas também influenciam grandemente a persistência dos inseticidas (FREED, 1979; RUEGG, 1986; BATISTA, 1999).

O processo de degradação do solo provocado pelos agrotóxicos inicia-se com a esterilização - eliminação de flora e fauna -, que, associada aos processos erosivos, leva a maior demanda por aplicação de produtos químicos (BARRETO; RIBEIRO, 2008).

A deficiência de micronutrientes, ocasionada pela perda de atividade biológica no solo, afeta a qualidade das plantas, tornando-as suscetíveis às pragas. Tal suscetibilida- 
de demanda doses cada vez maiores e/ou diversificadas de agrotóxicos, fechando assim o ciclo da contaminação do solo (ROMEIRO; ABRANTES, 1981).

Em saúde ambiental, é importante considerar diferentes tipos de indicadores biológicos para inferir efeitos na saúde de humanos. Dentre esses, destacam-se os indicadores (biomarcadores) de diferentes espécies da fauna silvestre, assim como os estudos experimentais.

Estudos realizados na fauna silvestre revelaram danos no sistema imunológico de diversas espécies provocados por exposição a agrotóxicos, corroborando achados obtidos em estudos experimentais e em humanos. Entre as espécies mais estudadas estão os peixes (BOWSER; FRENKEL; ZELIKOFF, 1994; DUNIER; SIWICKI, 1993; ZEEMAN, 1986; ARKOOSH; STEIN; CASILLAS, 1994; RAO, 1990; SIWICKI et al., 1990), as aves (GRASMAN, 1995; GRASMAN; SCANLON; FOX, 1994), as baleias (DE GUISE et al., 1995; AGUILAR; RAGA, 1993), os golfinhos (LAHVIS et al., 1993) e as focas.

A redução das populações de polinizadores em decorrência dos agrotóxicos é motivo de preocupação, a exemplo das abelhas. Estima-se que aproximadamente $73 \%$ das espécies vegetais cultivadas no mundo sejam polinizadas por alguma espécie de abelha. Esses insetos são importantes na polinização de muitas culturas agrícolas comerciais, tais como melão, maracujá, laranja, caju, alfafa e café (FREITAS; IMPERATRIZ-FONSECA, 2005; IMPERATRIZ-FONSECA et al., 2005).

Polinizadores também são importantes para a soja, pois, apesar dessa planta ser autofecundante, a polinização mediada por insetos é utilizada como estratégia de melhoramento com vista a aumentos na produção (ORTIZ-PEREZ et al., 2007).

Em Santa Catarina, o Centro de Pesquisa e Extensão Apícola (Cepea) investigou a mortandade de abelhas no Vale do Itajaí em julho de 2008, quando foi relatada perda de $70 \%$ de colmeias de um apicultor, e que o fato ocorria já há cinco anos. Tomando como base o histórico e a presença na região de várias culturas agrícolas comerciais, principalmente o arroz irrigado, amostras das abelhas foram analisadas e o resultado revelou contaminação por agrotóxicos organofosforados (LATOX, 2008). Embora não tenha sido relacionado a OPs, merece destaque o caso recente (maio de 2012) da mortandade de milhares de abelhas em Gavião Peixoto (SP), devida ao inseticida fipronil (aplicado nos canaviais vizinhos), conforme publicado na mídia e no site da Prefeitura Municipal de Gavião Peixoto7.

Pearce e colaboradores (1986) sugeriram que os agrotóxicos agem aditiva e sinergicamente com outros agentes químicos, concluindo que agricultores têm maior risco de desenvolver mieloma pela exposição não só a um determinado produto químico, mas também a outros produtos no ambiente de trabalho (exposição múltipla).

Em relação à toxicidade, importantes implicações toxicológicas dos OPs para a saúde pública e ambiental decorrem de suas propriedades químicas e físico-químicas.

Estudo realizado na bacia hidrográfica do rio Dourados (MS) por Scorza Jr e Silva

${ }^{7}$ www.gaviaopeixoto.sp.gov.br/detalhe_noticia.php?id=618, acessado em 11 jun. 2012. 
(2007), sobre o potencial de contaminação da água subterrânea por pesticidas, demonstrou que os agrotóxicos mais usados nessa bacia no ano de 2002 foram, em ordem decrescente: glifosato, 2,4-D, fipronil, metamidofós, imazaquim, parationa metílica, trifluralina, atrazina, cipermetrina, clorpirifós, monocrotofós, tiodicarbe, carbendazim e paraquate. As culturas que mais utilizaram agrotóxicos, em ordem decrescente de uso no ano de 2002, foram a soja, o milho, as pastagens, o trigo e o feijão. Os agrotóxicos que apresentaram os maiores potenciais de lixiviação e contaminação da água subterrânea na referida bacia hidrográfica foram o bentazona, imazetapir, fomesafem, 2,4-D, metamidofós, imazaquim, tiodicarbe e monocrotofós.

Estudo realizado em Caetés, distrito do município de Paty do Alferes (RJ), objetivou analisar o impacto provocado por agrotóxicos na microbiota do solo e sua relação com a saúde ambiental e da população.

A agricultura é a atividade econômica dominante na região, sendo cerca de $40 \%$ do total dessa atividade destinados ao cultivo de tomate e de grande número de outras olerícolas, tais como repolho, pimentão, vagem, pepino. Os agrotóxicos encontrados nas visitas feitas aos locais de armazenamento nas 43 lavouras de tomate foram 14 produtos comerciais - inseticidas, fungicidas e acaricidas: quatro da classe I (extremamente tóxico), seis da classe II (altamente tóxico), dois da classe III (medianamente tóxico) e dois da classe IV (pouco tóxico), segundo a classificação toxicológica do Ministério da Agricultura/Ministério da Saúde.

Os resultados evidenciaram que o solo se encontrava mais impactado pelo uso desses agrotóxicos no período em que ocorreu o plantio. Indicaram também que nesse período o solo apresentava alterações em suas propriedades biológicas e menor potencial produtivo decorrente do manejo ao qual é submetido, gerando estresse no ecossistema e a consequente queda de produtividade. Ficou evidenciada uma situação de estresse no solo estudado em Paty do Alferes. Essa situação é traduzida em perda de fertilidade do solo, perda de produtividade das plantações e aumento de pragas, com aumento - em frequência e em quantidade - na utilização de agrotóxicos (FERREIRA, 2006).

A maior parte dos agrotóxicos utilizados acaba atingindo o solo e as águas, principalmente pela deriva na aplicação para controle de ervas invasoras, pela lavagem das folhas tratadas, pela lixiviação, pela erosão, pela aplicação direta em águas para controle de vetores de doenças, pelos resíduos de embalagens vazias, pela lavagem de equipamentos de aplicação e por efluentes de indústrias de agrotóxicos. Ressalta-se a importância da conservação da diversidade de microrganismos do solo, pelo papel que desempenham no funcionamento dos ecossistemas (atividades microbianas de decomposição, degradação e desintoxicação de muitos contaminantes ambientais) (FERREIRA, 2006).

A Embrapa realizou análise de risco de contaminação de águas superficiais e subterrâneas em função de características dos agrotóxicos aplicados em manga e uva, na região do Vale do Rio São Francisco, no período de 1997 a 2001. Em uma primeira 
análise, o risco foi avaliado em função das características próprias dos agrotóxicos utilizados na região. Considerando-se as características do clima e do solo da região do submédio do rio São Francisco e por se tratar de área irrigada, os riscos de contaminação de águas superficiais e subterrâneas não podem ser desprezados. Soma-se a esse fator de risco o fato de que os solos da região são predominantemente arenosos, com limitações para o uso agrícola, em função da escassez de água e com probabilidade de ocorrência de fendilhamentos e ressecamentos.

Os resultados levam à conclusão de que, entre os agrotóxicos usados, os que apresentam maior mobilidade no ambiente são: acefato, dimetoato, diuron, fenarimol, fosetil, metalaxil, metamidofós, metidation, metomil, monocrotofós, tebuconazole, triclorfon, paclobutrazol, plocloraz e glifosato. Considerando que o metamidofós é o principal produto de degradação e metabolito do acefato, sua importância cresce no rol dos agrotóxicos para a contaminação das águas no contexto do estudo (EMBRAPA, s.d.). Ressalta-se a importância das águas do rio São Francisco para a dessedentação da população humana e de animais da região semiárida do Nordeste brasileiro, demonstrando um grande problema de saúde ambiental relacionado com a qualidade da água para abastecimento humano.

Os metabolitos da transformação ou produtos de degradação dos OPs podem ser ingeridos junto com os alimentos ou com a água. A transformação ocorre com os OPs que têm suas ligações tiofosfato $(\mathrm{P}=\mathrm{S})$ oxidadas a ortofosfato $(\mathrm{P}=\mathrm{O})$. Sob esta última forma, são potentes inibidores da acetilcolinesterase (COCKER et al., 2002). Assim, para melhor compreensão dos efeitos dos OPs sobre os sistemas biológicos é necessário o conhecimento das relações entre o agrotóxico e seus metabolitos ou derivados e os complexos enzimáticos dos seres vivos.

É ilustrativo o caso da China, que teve o auge das importações de agrotóxicos em 2004, com redução progressiva até 2008. Em 2007, esse país proibiu cinco OPs - metamidofós, parationa etílica; parationa metílica; monocrotofós e fosfamidon (SISCCOMEX, 2008) -, e em seguida a Anvisa identificou um aumento da importação do metamidofós. Grande parte dos estoques da China teria sido enviada para o Brasil. Em 2008, produtores brasileiros importaram US\$15,8 milhões em metamidofós (ver a figura 2.7).

A partir do uso disseminado dos OPs, vários efeitos adversos foram descritos em populações humanas e em outras espécies animais (GALLOWAY; HANDY, 2003). Dentre os efeitos tóxicos associados aos OPs encontram-se a neurotoxicidade, a imunotoxicidade, a carcinogenicidade, a desregulação endócrina e alterações no desenvolvimento do indivíduo.

Algumas condições como idade, gênero, via e dose de exposição contribuem para maior suscetibilidade individual, de maneira que crianças, idosos e mulheres em idade fértil constituem grupos populacionais de especial risco relacionado aos agrotóxicos (WOODRUFF, ZOTA; SCHWARTZ, 2011). 


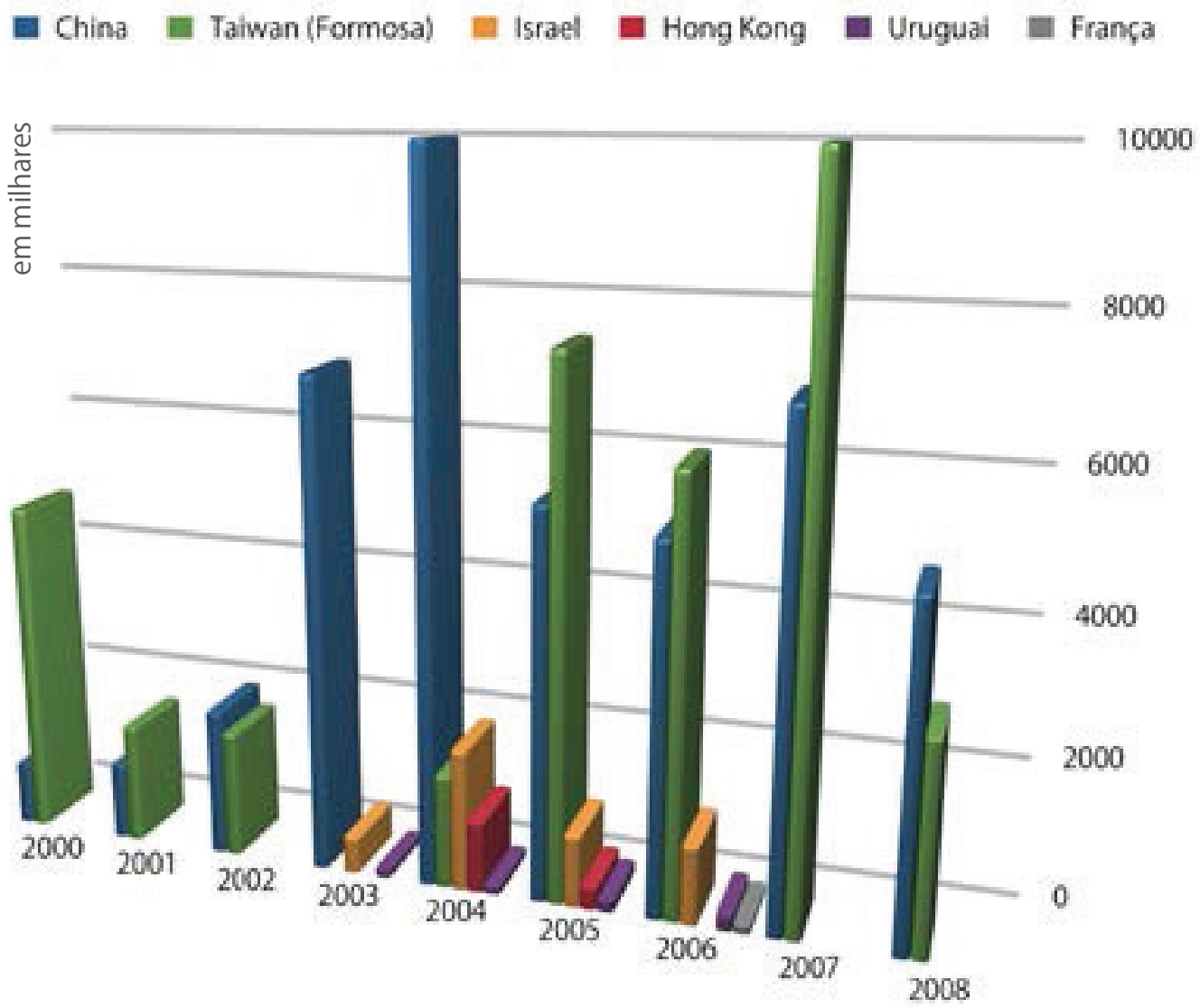

Fonte: Acriweb, acesso ao Sisccomex em 13 de agosto de 2008

Em regiões onde não existe infraestrutura suficiente para regular e controlar eficazmente o uso de agrotóxicos, como América Latina, África e Ásia, problemas decorrentes do uso de agrotóxicos na agricultura são ainda mais graves (NUNES; RIBEIRO, 1999).

Garcia (2001) encontrou uma relação direta entre as curvas de crescimento de registro de intoxicações e as vendas de agrotóxicos. Alves Filho (2002) corrobora esses dados de relação entre a quantidade de agrotóxicos utilizada, os valores das vendas dos produtos e os índices de intoxicação.

Em relação ao contexto de vulnerabilidades quanto à exposição, há grande subnotificação, ou notificação errônea, de intoxicações por agrotóxicos no Brasil (OPAS, 1996; SOBREIRA; ADISSI, 2003). Segundo estimativas da OMS, 70\% das intoxicações por agrotóxicos ocorridas no mundo se devem a exposições ocupacionais (OLIVEIRA-SILVA, ALVES; DELLA-ROSA, 2003). 
Com relação aos óbitos registrados no Sinitox, os três principais agentes químicos responsáveis por intoxicações são agrotóxicos de uso agrícola, raticidas e medicamentos. O percentual de letalidade por agrotóxicos no período de 1997 a 2001 foi algo em torno de 3\% (SINITOX, 2003).

Com relação aos casos de intoxicação ocupacional por agrotóxicos, o percentual de intoxicações foi bem maior, em média $28 \%$ do total de casos nos anos apresentados, revelando a enorme vulnerabilidade dos trabalhadores (SINITOX, 2009).

Em levantamento bibliográfico sobre estudos epidemiológicos de intoxicação por agrotóxicos no Brasil, Faria, Fassa e Fachinni (2007) destacaram diversos problemas contextuais, de vulnerabilidade e de suscetibilidade na atividade de aplicação de agrotóxicos e de modos de aplicação (quadro 2.2).

Quadro 2.2 - Problemas identificados em estudos brasileiros decorrentes do uso de agrotóxicos

\begin{tabular}{|l|l|}
\hline Tipo de problema & Autores \\
\hline Sujeição a más condições de trabalho & ETGES et al., 2002 \\
\hline Baixa escolaridade & OLIVEIRA-SILVA et al., 2001 \\
\hline $\begin{array}{l}\text { Aumento do risco por fatores socioeco- } \\
\text { nômicos }\end{array}$ & $\begin{array}{l}\text { OLIVEIRA-SILVA et al., 2001 } \\
\text { FARIA et al., 2004 }\end{array}$ \\
\hline $\begin{array}{l}\text { Equipamentos de proteção individual } \\
\text { (EPIs) inadequados, não disponíveis ou } \\
\text { não utilizados }\end{array}$ & $\begin{array}{l}\text { ARAÚJO; NOGUEIRA; AUGUSTO, 2000; MOREIRA; } \\
\text { JACOB; PERES, 2002 SOARES; ALMEIDA; MORO, } \\
\text { 2003 DELGADO, 2004 CASTRO; CONFALONIERI, } \\
\text { 2005 FARIA et al., 2004 }\end{array}$ \\
\hline Exposição de mulheres em idade fértil & $\begin{array}{l}\text { MOREIRA; JACOB; PERES, 2002 } \\
\text { FARIA et al., 2004 }\end{array}$ \\
\hline Exposição em idade precoce & MOREIRA; JACOB; PERES, 2002 \\
\hline $\begin{array}{l}\text { Orientação recebida apenas do } \\
\text { vendedor }\end{array}$ & SOARES; ALMEIDA; MORO, 2003 \\
\hline Destino inadequado de embalagens & $\begin{array}{l}\text { ARAÚJO; NOGUEIRA; AUGUSTO, 2000 } \\
\text { FARIA et al., 2000 }\end{array}$ \\
\hline $\begin{array}{l}\text { Pouca conscientização sobre os riscos } \\
\text { dos produtos }\end{array}$ & CASTRO; CONFALONIERI, 2005 \\
\hline Uso de produtos classe I & DELGADO, 2004 \\
\hline Reentrada na área pós-aplicação & FARIA et al., 2004 \\
\hline Aumento da carga de exposição & FARIA et al., 2004 \\
\hline
\end{tabular}

Fonte: FARIA; FASSA; FACHINNI (2007). 
Os trabalhadores são um dos grupos populacionais mais afetados pelos agrotóxicos, e muito disso se deve aos contextos produtivos. Em estudo realizado em municípios do estado do Amazonas (Manaus, Iranduba, Careiro da Várzea e Manacapuru), Waichman (2012) verificou que os agricultores têm usado intensivamente os agrotóxicos na produção de hortaliças. E concluiu que os agricultores não estavam preparados ou protegidos para essa tecnologia e que os riscos dos agrotóxicos para a saúde humana e para o ambiente foram desconsiderados. Não são utilizados EPIs por serem caros, desconfortáveis e inadequados para o clima quente da região. A falta de treinamento e o escasso conhecimento sobre os perigos dos agrotóxicos contribuem para a manipulação incorreta durante a preparação, aplicação e disposição das embalagens vazias. Nessas condições é alta a exposição dos agricultores, de suas famílias, dos consumidores e do ambiente.

Todas essas situações revelam a complexidade do contexto em que se dá a utilização dos agrotóxicos na atividade agrícola, e estão diretamente associadas à toxicidade desses compostos.

Um estudo realizado em seis propriedades produtoras de tomate em Camocim de São Félix (PE) revelou que 13,2 \% $(\mathrm{n}=159)$ dos trabalhadores entrevistados informavam ter sofrido algum tipo de intoxicação. Desses, 45 referiram mal-estar durante a aplicação de produtos, $70 \%$ das mulheres citaram problemas na gestação acarretando perda do feto e 39,4\% fizeram referência à perda de um filho no primeiro ano de vida (ARAÚJO; NOGUEIRA; AUGUSTO, 2000).

Em Minas Gerais, estudo realizado por Soares, Almeida e Moro (2003) referente ao período entre 1991 e 2001 detectou o alto grau de risco de agravos à saúde a que estão sujeitos trabalhadores rurais em contato com agrotóxicos: foram encontrados $50 \%$ dos entrevistados $(\mathrm{n}=1.064)$ moderadamente intoxicados.

Oliveira-Silva e colaboradores (2001), em estudo realizado em Nova Friburgo (RJ), identificaram que $10 \%$ dos trabalhadores investigados apresentavam sinais e sintomas de intoxicação. Os autores estimaram que o número esperado de intoxicações agudas por agrotóxicos entre trabalhadores agrícolas brasileiros seria de 360.000 casos a cada ano somente no meio rural.

A exposição aos OPs ocorre tanto em áreas rurais quanto em zonas urbanas, o que expõe a população geral aos danos causados por essas substâncias Exemplo de exposição urbana é dado por um estudo de coorte retrospectivo que verificou que o uso de OPs em orquidário na área urbana de Petrópolis (RJ) foi responsável pela intoxicação de pelo menos 16 moradores de locais próximos ao orquidário. O mesmo estudo verificou que pessoas que, por passarem mais tempo em casa, ficaram mais tempo expostas às substâncias tiveram mais chance de se intoxicar (OLIVEIRA; GOMES, 1990).

No meio urbano do estado do Rio de Janeiro, do total de casos fatais de intoxicações registrados pelo Instituto Médico-Legal (IML) entre 2000 e 2001, 12,6\% apresentaram evidências científicas de associação com agrotóxicos (OLIVEIRA-SILVA; ALVES; DELLA-ROSA, 2003). 
No Rio Grande do Sul, um estudo de base populacional descreveu o perfil sociodemográfico e a prevalência de algumas morbidades. Entre os resultados obtidos, destaca-se que 75\% dos trabalhadores utilizavam agrotóxicos, a maioria OPs (FARIA et al., 2000). A utilização de agrotóxicos caracterizou-se como intensa durante sete meses do ano (em $85 \%$ dos estabelecimentos); o tipo de agrotóxico utilizado variou conforme a cultura; $12 \%$ dos trabalhadores que utilizavam esses produtos referiram intoxicação pelo menos uma vez na vida, e a prevalência de transtornos psiquiátricos foi de $36 \%$. Nas propriedades maiores (de 25 a 100 ha) e onde se utilizavam mais agrotóxicos, observou-se um aumento do risco para intoxicações. Nesse mesmo estado, um estudo transversal sobre saúde mental de agricultores da Serra Gaúcha mostrou forte associação entre intoxicações por agrotóxicos e o desenvolvimento de transtornos psiquiátricos menores (FARIA et al., 1999).

Pires, Caldas e Recena (2005a, 2005b) estudaram no Mato Grosso do Sul, no período de 1992 a 2002, as intoxicações provocadas por agrotóxicos na microrregião de Dourados. Foi observada correlação entre a prevalência de intoxicações e de tentativas de suicídio pela exposição a agrotóxicos, principalmente nas culturas de algodão e feijão. Os municípios de Dourados, Fátima do Sul e Vicentina se apresentaram como mais críticos na referida microrregião. Os inseticidas foram a principal classe de agrotóxicos envolvidos nas ocorrências, principalmente organofosforados e carbamatos, corroborando outros estudos (SENANAYAKE; PEIRES, 1995; SAADEH et al., 1996; SOTH; HOSOKAWA, 2000; SOARES; ALMEIDA; MORO, 2003).

Um estudo realizado no Núcleo Rural de Vargem Bonita (DF), área de produção intensiva de hortaliças, revelou que a intoxicação por metamidofós foi encontrada em cinco $(62,5 \%)$ dos oito trabalhadores que aplicavam o produto. Estes revelaram que logo após a aplicação do inseticida, e por cerca de 24 horas depois, sentiam dores de cabeça, tontura e enjoo (CASTELO BRANCO, 2003). As mesmas queixas foram reveladas por agricultores de Nova Friburgo, RJ (BULL; HATHWAY, 1986) e do Vale do São Francisco, PE (ARAÚJO; NOGUEIRA; AUGUSTO, 2000).

\section{caso dos organoclorados}

Os inseticidas organoclorados foram introduzidos em meados da década de 40, após a Segunda Guerra Mundial (ANDRADE FILHO; CAMPOLINA; DIAS, 2001), e amplamente utilizados na agricultura e, na saúde pública (OGA, 2003), no combate à malária $\mathrm{e}$ na prevenção de epidemias de tifo transmitidas por piolhos (FLORES et al., 2004).

O dicloro-difenil-tricloroetano (DDT) foi o precursor dos organoclorados. Segundo Flores e colaboradores (2004), em 1940 Paul Mueller, da companhia suíça Geisy, observou que o DDT, sintetizado por Zeidler em 1874, era um potente inseticida. Sua pronunciada propriedade inseticida, aliada à baixa solubilidade em água, alta persis- 
tência e sua forma de ação, desconhecida até aquele momento, propiciou resultados inseticidas potentes, e seu uso rapidamente se expandiu.

O poder residual, antes considerado como qualidade positiva desses compostos, começou a ser encarado como sério inconveniente, por gerar grave impacto ecológico. Pela necessidade de resguardar a saúde humana e animal e o meio ambiente da ação de agrotóxicos com persistência ambiental e/ou periculosidade, a maioria dos organoclorados destinados ao uso na agricultura teve sua comercialização, uso e distribuição proibidos no Brasil pela Portaria n. 329, de 2 de setembro de 1985 (BRASIL. MAPA, 1985; OGA, 2003; FLORES et al., 2004).

Para uma compreensão sistêmica de sua implicação para a saúde humana e o ambiente, deve-se, inicialmente, entender que se trata de poluentes orgânicos persistentes (POPs), outra denominação para as substâncias tóxicas persistentes (STPs).

De modo geral, pode-se dizer que as propriedades físico-químicas de uma substância dependem do tipo de átomos que formam a sua molécula e da posição que esses átomos ali ocupam. Substância persistente é aquela cujas moléculas são estáveis e não facilmente destruídas, permanecendo no ambiente após o uso para o qual foi destinada. A estabilidade de um composto químico orgânico depende também de sua estrutura química. Assim, compostos cíclicos são mais estáveis do que compostos alifáticos, e os aromáticos são mais estáveis que os primeiros.

As estruturas ramificadas são mais estáveis que as estruturas lineares. A ligação cloro-carbono é muito resistente à hidrólise, portanto contribui para a resistência da molécula à degradação biológica e fotolítica.

Os compostos que têm átomos de cloro ligados aos anéis aromáticos são mais estáveis do que substâncias cujas moléculas têm estrutura linear. A estabilidade de um anel aromático cresce com o número de átomos de cloro presentes.

As estruturas químicas dos POPs geralmente são cíclicas, ramificadas e cloradas. Os POPs, por suas características físico-químicas, não se decompõem facilmente, mantendo-se inalterados por longo tempo no ambiente, ou produzindo metabolitos tóxicos decorrentes de degradação no ambiente.

Os POPs podem ser transportados, pelo ar e pelos rios ou oceanos, a longas distâncias a partir do local onde foram originadas. Em maio de 2001 foi assinada a Convenção de Estocolmo, que previu que inicialmente seriam banidos ou teriam seu uso restringido 12 POPs: oito agrotóxicos (DDT, aldrin, dieldrin, clordano, endrin, heptacloro, mirex, toxafeno); dois hexaclorobenzenos industriais (HCBs) e bifenilas policloradas (PCBs) e dois subprodutos não intencionais, gerados da combustão de matéria orgânica (dioxinas e furanos). Foi uma medida de precaução para evitar danos ao ambiente irreversíveis ou de muito difícil reparo. Além desses produtos listados pela Convenção de Estocolmo (2001), há ainda grande número de outros que têm essas mesmas características e aguardam avaliação para terem seu uso proibido ou restringido. 
Os POPs pertencem a dois subgrupos de hidrocarbonetos policíclicos aromáticos, e seus derivados halogenados compreendem vasta quantidade de compostos químicos de uso variado.

As características dos POPs são bastante complexas, por terem origens variadas e atuarem em função não somente da natureza do composto químico, mas de sua interação com fatores ambientais tais como localização geográfica, tipo de solo, temperatura, proximidade com corpos d'água, ocorrência de correntes aéreas etc.

As características de persistência, lipossolubilidade, resistência a ou dificuldade de degradação, bioacumulação e a propriedade de serem transportados a longas distâncias fazem dos POPs moléculas perigosas, que ocasionam efeitos adversos à saúde humana e ao meio ambiente (DUARTE, 2002).

A biodegradação de uma substância pode ocorrer de duas formas: pela mineralização completa do substrato até seus constituintes elementares ou pela degradação parcial formando metabolitos que podem ser ainda mais tóxicos que a substância original. Para o ambiente, a primeira é menos problemática que a segunda.

Dependente das condições ambientais e da estrutura molecular, a persistência dos compostos pode ser reduzida por processos no ambiente como biotransformação, oxidação abiótica, hidrólise e fotólise. Nas regiões polares os POPs são mais estáveis do que nos trópicos, onde a ação combinada de luz e calor favorece a sua degradação. Além disso, uma substância não persistente cujo produto de degradação é persistente deverá também ser considerada como tal (DUARTE, 2002).

A bioconcentração é um processo que gera o aumento da concentração de uma substância química em um organismo aquático, em relação a sua concentração na água, devido à incorporação através de sua absorção unicamente pela água, a qual pode ocorrer pela superfície respiratória e/ou pela pele. A biomagnificação é a acumulação de uma substância na biota em toda a extensão da cadeia alimentar através da alimentação. A bioacumulação é o somatório desses dois processos. Esses três processos compõem, juntos, um processo pelo qual a concentração de poluentes nos animais aumenta na direção do topo da cadeia alimentar (MIRANDA, 2006).

Para que esses processos ocorram, a substância deve ser lipossolúvel, ou seja, ter a propriedade de se dissolver referencialmente em gorduras, podendo assim se fixar nos tecidos dos seres vivos e ali permanecer quando persistentes. A lipossolubilidade é também função do alto grau de cloração dessas moléculas, que as faz capazes de atravessar com facilidade a estrutura fosfolipídica das membranas biológicas e de se acumular no tecido adiposo (DUARTE, 2002).

A dispersão ambiental dos POPs é a propriedade de maior impacto, transformando-os num problema de dimensões globais, razão pela qual a regulamentação de sua produção e seu emprego é intergovernamental. Sua capacidade de se transportar a longas distâncias é decorrente de sua semivolatilidade. A grandeza físico-química que mede essa propriedade é a pressão de vapor. 
Os POPs apresentam valores de pressão de vapor que lhes permitem evaporar e condensar sucessivamente, dependendo das condições em que se encontram. A pressão de vapor de um composto, responsável por suas propriedades evaporativas, é fortemente dependente da temperatura: as substâncias tendem a evaporar quanto mais alta a temperatura e, consequentemente, se condensam a temperaturas mais baixas.

As substâncias persistentes utilizadas nos trópicos evaporam, e por processos sucessivos de condensação/evaporação, dependentes da temperatura, se distribuem em direção aos polos com velocidade em função de sua pressão de vapor. Esse mecanismo explica a presença de POPs nas regiões árticas onde nunca foram utilizados (LEMOS, 2001).

Por todas essas características, os POPs são substâncias químicas sintéticas tóxicas para os seres vivos. A primeira evidência que relacionou os POPs a danos à vida selvagem foi descoberta na América do Norte nos anos 1960, quando Rachel Carson diagnosticou que a população de falcões peregrinos estava diminuindo devido à contaminação por agrotóxicos.

A partir daí, uma lista crescente de evidências revelou serem os POPs causadores de uma série de efeitos negativos em espécies predadoras no topo da cadeia alimentar. Dentre esses efeitos, encontram-se: problemas na reprodução e declínio populacional de animais silvestres; funcionamento anormal das tireoides e outras disfunções hormonais; feminilização de machos e masculinização de fêmeas; sistema imunológico comprometido; tumores e cânceres; anormalidades comportamentais e maior incidência de má-formação fetal (teratogênese). Com o passar do tempo, evidências semelhantes foram observadas em humanos, além de distúrbios no aprendizado: alterações no sistema imunológico; problemas na reprodução, como infertilidade; lactação diminuída em mulheres em período de amamentação; doenças como endometriose; aumento na incidência de diabetes etc.

A exposição do ser humano aos POPs se dá de diferentes formas: pela alimentação, pela água, pelo ar, pelo solo e pelas condições de trabalho. Em particular, alimentos gordurosos como a carne, o peixe e laticínios podem conter POPs contaminantes, que são resíduos de agrotóxicos devido a rações oriundas de utilização durante o cultivo e na colheita desses produtos organoclorados.

Muitos POPs danificam o sistema imunológico dos organismos vivos nos quais se acumulam, podendo imitar hormônios, interferir nos sistemas endócrinos e afetar a fertilidade dos seres humanos e dos animais; a diminuição da fertilidade ameaça a sobrevivência de populações inteiras de seres vivos (PAT; LUSCOMBE; SIMPSON, 1998). A exposição a inseticidas organoclorados pode levar a alterações mentais em decorrência da neurotoxicidade (HSDB, 2005).

A preocupação acerca dos efeitos de longo prazo dos organoclorados tem aumentado, pois a maioria desses contaminantes se bioacumulam, permanecendo, principalmente, nos tecidos gordurosos e podendo agir sinergicamente com estrógenos en- 
dógenos, na interferência (disrupção) do sistema endócrino de animais e humanos expostos (SOTO; CHUNG; SONNENSCHEIN, 1994).

A saúde de trabalhadores em diversas áreas é ameaçada devido à exposição a esses produtos durante a jornada de trabalho. Além desses, as mulheres em período fértil e as crianças constituem os grupos humanos mais vulneráveis.

Todas essas questões têm sido estudadas e consideradas nos últimos quarenta anos, e convenções internacionais foram sendo estabelecidas para o disciplinamento do comércio e uso dessas substâncias ou produtos técnicos.

O processo conhecido como procedimento de Prévia Informação e Consentimento (PIC) foi aditado em 1989 com a finalidade de controlar as importações de produtos químicos indesejados já proibidos ou severamente restringidos. A Convenção de Roterdã sobre o Procedimento de Consentimento Fundamentado Prévio Aplicável a Certos Pesticidas e Produtos Químicos foi instituída e assinada pelo Brasil em 11 de setembro de 1998. O procedimento PIC vem funcionando por adesão voluntária desde o ano de 1989, sendo atualmente aplicado por cerca de 150 países.

Em Estocolmo, em encontro realizado entre 21 e 23 de maio de 2001, foi assinada por cem países, entre os quais o Brasil, a Convenção de Estocolmo sobre Poluentes Orgânicos Persistentes, que tem como princípios a proteção da saúde humana e do ambiente contra os poluentes orgânicos persistentes. O Senado Federal brasileiro levou três anos para ratificá-la, o que só aconteceu em 2004.

Pela importância histórica do uso de organoclorados no Brasil, e pela recente conclusão pela proibição do registro do endosulfan no país, torna-se necessário compreender as implicações dos organoclorados para o ambiente e a saúde humana. Principalmente se considerarmos a tensão permanente quanto à reintrodução de organoclorados no país para utilização em saúde pública, especialmente no controle vetorial da malária (os organoclorados já foram reintroduzidos na África).

No Brasil, segundo dados do Sistema de Agrotóxicos Fitossanitários (Agrofit) do MAPA, vários produtos formulados registrados estão para ser reavaliados, sendo que o endosulfan foi proibido em 2010 com uma fase de descontinuidade do uso até 2013.

Revisão publicada em 2007 sobre substâncias tóxicas persistentes (STPs) no Brasil, entre as quais está o endosulfan, mostra que, apesar de parcialmente proibidas no país, níveis dessas substâncias estão presentes em diferentes matrizes ambientais (solo, sedimento, água, ar, biota), atingindo valores muito acima dos limites legislados, em áreas consideradas críticas, envolvendo sua dinâmica, transformação e biomagnificação no ambiente. Isso tem ocasionado sérios problemas ambientais e riscos para a saúde humana. Em tecidos humanos tais substâncias são detectados no leite, no sangue, no cabelo (ALMEIDA et al., 2007). Entre as STPs estão os organoclorados.

$\mathrm{O}$ endosulfan é ingrediente ativo (IA) de vários inseticidas/formicidas/acaricidas. Trata-se de um veneno muito perigoso que, como teve sua proibição no Brasil mediante um procedimento denominado "banimento faseado" - que decidiu a proibição de 
sua importação a partir de 2011, a proibição de sua fabricação em território nacional a partir de 31 de julho de 2012 e a proibição de sua comercialização e uso a partir de 31 de julho de 2013 -, continua sendo um problema de saúde ambiental.

Os efeitos negativos do endosulfan e seus isômeros $\alpha$, $\beta$, bem como do seu metabolito sulfato na saúde humana e no ambiente, comprovados por evidências científicas, estão amplamente documentados em Nota Técnica da Anvisa, que propõe o seu banimento do país, especialmente por: 1- apresentarem fácil absorção pelas vias oral, inalatória e dérmica em humanos, promovendo estímulo do Sistema Nervoso Central (SNC) como a principal característica nos casos de intoxicação aguda; 2 - estarem associados a efeitos estrogênicos e imunossupressores, exercendo efeitos sobre a reprodução; e 3 apresentarem genotoxicidade nos níveis mutagênicos e cromossômicos, podendo estar implicados em ação carcinogênica. Estudos subcrônicos e crônicos sugerem que o fígado, os rins, o sistema imunológico e os testículos são os principais alvos (HSDB, 2005).

As populações notadamente suscetíveis ao endosulfan, assim como a outros organoclorados, incluem as mulheres em período fértil, os nascituros, os neonatos, os idosos e pessoas com comprometimentos hepáticos, renais, imunológicos, hematológicos ou neurológicos (NAQVI; VAISHNAVI, 1993).

A cadeia produtiva do cloro, bem como outros aspectos relacionados aos produtos formulados, resíduos e metabolitos e suas implicações químicas, bioquímicas, ambientais, toxicológicas e de saúde, também deveria ser incorporada à avaliação sistêmica por parte da Anvisa, pela importante nocividade sobre o ambiente e a saúde humana.

Um estudo acerca da comercialização e utilização de agrotóxicos no polo fruticultor de Petrolina (PE) e Juazeiro (BA) constatou que dois produtos formulados à base de endosulfan estavam entre os mais vendidos pelas lojas de agrotóxicos (BEDOR et al., 2007), embora não sejam autorizados para a produção de frutas.

Conforme informações obtidas no Mapa da Injustiça Ambiental e Saúde no Brasil (atualizadas em dezembro de 2009), o derramamento de oito mil litros de endosulfan no rio Paraíba do Sul, em Resende (RJ), foi um caso emblemático. O Paraíba do Sul nasce na Serra da Bocaina, no estado de São Paulo, percorre um pequeno trecho do sudeste de Minas Gerais, atravessa boa parte do estado do Rio de Janeiro e deságua no norte fluminense, quase na fronteira com o Espírito Santo. No Rio de Janeiro ele cruza pelo menos 37 municípios e se constitui na principal fonte de água potável da Região Metropolitana do estado.

O derramamento provocou a morte de milhares de toneladas de peixes (figura 2.8), justamente na época da piracema, quando os cardumes sobem o rio para desovar, e deixou mais de setecentas mil pessoas sem abastecimento de água e mais de vinte mil pescadores sem poder trabalhar.

A produtora de agroquímicos Servatis, empresa responsável pela poluição, não comunicou o vazamento às autoridades ambientais e de saúde, o que atrasou a iniciativa de qualquer ação preventiva ou de combate aos efeitos do acidente. A contaminação 
só foi detectada quando chegou à altura de Barra Mansa (RJ), com dezenas de toneladas de peixes já dizimadas. A Servatis realizou apenas uma autodenúncia dias após o acidente, mesmo assim omitindo suas reais dimensões - notificou o vazamento de apenas 1.500 litros do agrotóxico ${ }^{8}$.

$\mathrm{O}$ endosulfan é uma importante causa de morbidade e mortalidade não só na Índia, mas também em diversos países em desenvolvimento (YAVUZ et al., 2007; OKTAY et al., 2003).

No cenário ocupacional, a exposição ao endosulfan ocorre predominantemente por via dérmica e inalatória (ATSDR, 2000). Os trabalhadores podem ser expostos durante a mistura, o carregamento, a aplicação do composto ou na reentrada em áreas tratadas (EPA, 2002). $\mathrm{O}$ endosulfan é eficientemente

Figura 2.8 - Mortandande de peixes por vazamento de endossulfam pela Servatis no rio Paraíba do Sul em 2008

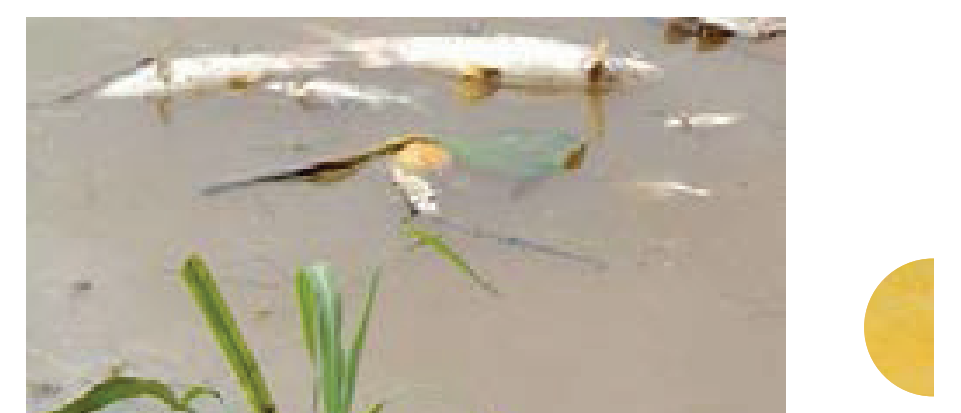
absorvido quando em contato com a pele (FLORES et al., 2004).

O Programa de Análise de Resíduos de Agrotóxicos (PARA) da Anvisa divulgou resultados de 2010 segundo os quais foram encontradas cinquenta amostras insatisfatórias com endosulfan em oito tipos de alimentos (alface, cebola, couve, laranja, mamão, morango, pepino e pimentão).

Vários resultados insatisfatórios se apresentaram nas amostras analisadas no programa, com resíduos de agrotóxicos não autorizados para a cultura ou níveis de resíduos acima do limite máximo de resíduo (LMR). O endosulfan foi detectado em três culturas para as quais não possui autorização de uso, as de batata, tomate e cenoura.

Pessoas que moram próximo a locais contaminados com organoclorados têm alto risco de exposição (ATSDR, 2000).

${ }^{8}$ Para ler a íntegra desse caso de conflito envolvendo injustiça ambiental e saúde no Brasil, acessar http://conflitoambiental.icict.fiocruz.br/index.php? pag=ficha\&cod=119. 
O endosulfan é um agrotóxico semivolátil e persistente (ERMA, 2007). As substâncias semivoláteis podem percorrer longas distâncias, tanto na forma particulada quanto na gasosa, ou adsorvidas em partículas sólidas; uma vez na troposfera, o tempo de sua permanência e a distância por elas percorridas são influenciados pelas condições meteorológicas e por vários processos de remoção, dos quais a deposição e fototransformação são os mais importantes. Perdas atmosféricas de agrotóxicos durante e após a aplicação contribuem para a ocorrência dessas substâncias em locais distantes (GERMAN FEDERAL ENVIRONMENT AGENCY, 2007).

A contaminação ambiental por endosulfan ocorre durante o processo de fabricação, transporte, distribuição, aplicação e depósito inadequado de embalagens e resíduos. $\mathrm{O}$ endosulfan adere a partículas argilosas e é facilmente detectado em solos contaminados, onde permanece por vários anos, dependendo de fatores que afetem sua degradação (NAQVI; VAISHNAVI, 1993). É liberado no meio ambiente principalmente por volatilização e oxidação a endosulfan sulfato (SUTHERLAND et al., 2002). No meio ambiente, o endosulfan pode ser convertido por hidrólise ou oxidação, formando endossulfato (endosulfan sulfato) ou endodiol (endosulfan diol), respectivamente.

O endosulfan é um inseticida razoavelmente persistente: sua meia-vida varia de alguns meses a mais de dois anos no solo e de um a seis meses na água, dependendo das condições climáticas e anaeróbicas e do $\mathrm{pH}$. Em água, ele é principalmente degradado a endosulfan diol e no solo a endosulfan sulfato. A degradação do endosulfan na água é um processo complexo e depende dos tipos de sedimentos presentes, dos microrganismos, do $\mathrm{pH}$ e da quantidade de oxigênio (NAQVI; VAISHNAVI, 1993; GUPTA; GUPTA, 1979).

Dados disponíveis sugerem que o endosulfan sulfato é mais persistente do que o composto parental. A meia-vida estimada para a combinação dos resíduos tóxicos (endosulfan e endosulfan sulfato) varia de nove meses a seis anos (ERMA, 2007).

O endosulfan é muito tóxico para quase todos os organismos. Esse organoclorado é rapidamente metabolizado, e um dos seus metabolitos, o endosulfan sulfato, apresenta uma toxicidade aguda semelhante àquela da substância original. Já o derivado endosulfan diol é três vezes menos tóxico que o composto parental (GERMAN FEDERAL ENVIRONMENT AGENCY, 2007).

Animais marinhos têm mostrado acumular quantidades consideráveis de endosulfan (NAQVI; VAISHNAVI, 1993).

Diferentemente de seus isômeros, o endossulfato se acumula no tecido adiposo dos animais e é o principal resíduo detectado no tecido animal após exposição. Consequentemente, a contaminação de pastos pode resultar em quantidades muito elevadas de resíduos de endossulfato em animais que se desenvolvem no local (SUTHERLAND et al., 2002).

Os resíduos do endosulfan no meio ambiente são problemáticos, pois ele é tóxico para peixes em baixas quantidades, com concentrações entre 0,01 e $10 \mu \mathrm{g}$ L-1 causando mortalidade de $50 \%$ da maioria das espécies em 24 horas em condições laboratoriais (SUTHERLAND et al., 2002). Além disso, o endosulfan se bioacumula em peixes na 
ordem de mil vezes em um curto período (96 horas) (ERMA, 2007); trata-se de importante aspecto para a segurança alimentar, com implicações para a cadeia alimentar.

A morte de peixes, extremamente sensíveis ao inseticida, tem sido relatada em várias ocasiões como resultado do escoamento do endosulfan para rios. A aplicação de endosulfan em áreas alagadiças, nos níveis recomendados, também pode resultar em mortalidade de peixes (NAQVI; VAISHNAVI, 1993).

Os fatores que afetam a toxicidade do endosulfan para organismos aquáticos incluem temperatura, salinidade e estágio da vida (jovem-adulto). A toxicidade do endosulfan geralmente aumenta com a elevação da temperatura, e organismos marinhos são geralmente mais sensíveis do que organismos de água doce. Existem vários estudos acerca da toxicidade aguda do endosulfan para peixes e invertebrados aquáticos. Há variação considerável nos valores de LC50 e relatos de efeitos no crescimento e na reprodução e em parâmetros fisiológicos (NAQVI; VAISHNAVI, 1993).

A literatura recente indica que o endosulfan tem potencial de causar desregulação endócrina tanto em espécies terrestres quanto em aquáticas. Os efeitos observados foram desenvolvimento alterado em anfíbios; secreção de cortisol reduzida em peixe; alteração em níveis hormonais e desenvolvimento do trato genital em pássaros; atrofia testicular e produção reduzida de esperma em mamíferos (GERMAN FEDERAL ENVIRONMENT AGENCY, 2007).

Certamente o endosulfan tem grande participação nos casos de intoxicação por agrotóxicos no Brasil, em função de sua grande utilização e alta toxicidade. Infelizmente, o sub-registro e a insuficiência dos sistemas de notificação não permitem uma estimativa confiável de seu impacto no cenário brasileiro.

\section{As embalagens dos agrotóxicos como indicadores de poluição e responsabilização dos produtores e usuários}

As embalagens vazias de agrotóxicos são descartadas sem controle e fiscalização, e a antiga prática de enterrá-las é atualmente condenada devido aos altos riscos de contaminação do solo e das águas subterrâneas Os resíduos presentes em embalagens de agrotóxicos e afins, quando abandonados no ambiente ou descartados em aterros e lixões, contaminam o solo e, sob a ação da chuva, são carreados para águas superficiais e subterrâneas.

Desde a Lei 9.974, de 6 de junho de 2000, posteriormente atualizada pelo Decreto 4.074, de 4 de janeiro de 2002, o destino de resíduos e embalagens vazias dos agrotóxicos tem estado em pauta. O setor do empresariado do agrotóxico, especialmente representado pela Associação Nacional de Defesa Vegetal (Andef), procurou, às vésperas da publicação da Lei de Crime Ambiental (Lei n. 9.605/1998), se adiantar e dar sua "contribuição" para a solução desse problema. Disponibilizando material publicitário, 
cartilhas didáticas e construindo espaços para a recepção das embalagens vazias, deixou para as municipalidades a responsabilidade pela coleta das embalagens e para os trabalhadores rurais a tríplice lavagem dos equipamentos de aplicação de agrotóxicos e o envio das embalagens para serem recolhidas. Esse material didático em nenhum momento apresenta esclarecimentos sobre a toxicidade dos venenos e ainda culpabiliza os agricultores e as prefeituras pela poluição ambiental. Além disso, como as embalagens são lavadas em água de múltiplo uso, no que pode vir a ser ser mais uma fonte de exposição humana aos venenos. Considerável número de pesquisas não aborda o tema das

\begin{tabular}{|c|c|c|c|c|c|c|c|}
\hline UF / Destino & $v^{20}$ & & & & & & \\
\hline Brasil & 8,9 & 1,2 & 3,5 & 25,3 & 13,4 & 49,4 & 1,9 \\
\hline Rondônia & 8,3 & 7,6 & 5,2 & 23,9 & 30,9 & 28,7 & 2,0 \\
\hline Acre & 8,9 & 5,1 & 7,7 & 58,6 & 12,3 & 6,4 & 3,0 \\
\hline Amazonas & 9,5 & 0,7 & 9,3 & 65,3 & 8,5 & 5,8 & 4,4 \\
\hline Roraima & 7,0 & 1,8 & 6,0 & 68,5 & 7,3 & 9,4 & 2,1 \\
\hline Pará & 15,4 & 2,6 & 7,9 & 52,3 & 10,5 & 10,8 & 3,5 \\
\hline Amapá & 3,5 & 0,9 & 7,4 & 68,0 & 7,8 & 9,5 & 3,9 \\
\hline Tocantins & 7,3 & 2,0 & 5,6 & 54,3 & 10,7 & 19,6 & 2,4 \\
\hline Maranhão & 53,5 & 2,0 & 5,0 & 29,3 & 4,1 & 4,0 & 4, \\
\hline Piauí & 32,2 & 0,6 & 3,6 & 51,8 & 3,3 & 5,5 & 4,6 \\
\hline Ceará & 31,8 & 0,7 & 5,9 & 52,8 & 4,5 & 2,2 & 4, \\
\hline Rio Grande do Norte & 15,0 & 0,4 & 9,0 & 69,4 & 2,7 & 2,6 & 3, \\
\hline Paraíba & 23,8 & 1,0 & 7,6 & 59,6 & 4,1 & 2,6 & 3,2 \\
\hline Pernambuco & 21,8 & 1,2 & 8,9 & 54,2 & 7,4 & 6,8 & 3,4 \\
\hline
\end{tabular}


embalagens de agrotóxicos como importante fonte de exposição humana e ambiental a esses biocidas. É necessário um diagnóstico situacional da problemática ambiental, em especial relacionado à contaminação do solo pela grande quantidade de embalagens descartadas (BEDOR et al., 2009).

O Censo Agropecuário de 2006 (tabela 1.009 no site do IBGE) registra que metade dos estabelecimentos ainda não apresenta destino adequado de seu lixo tóxico e evidencia, mais uma vez, a desigualdade sociorregional, que também se expressa nas ações de descarte de embalagens de agrotóxicos e dos resíduos tóxicos que nelas permanecem (quadro 2.3).

UF / Destino

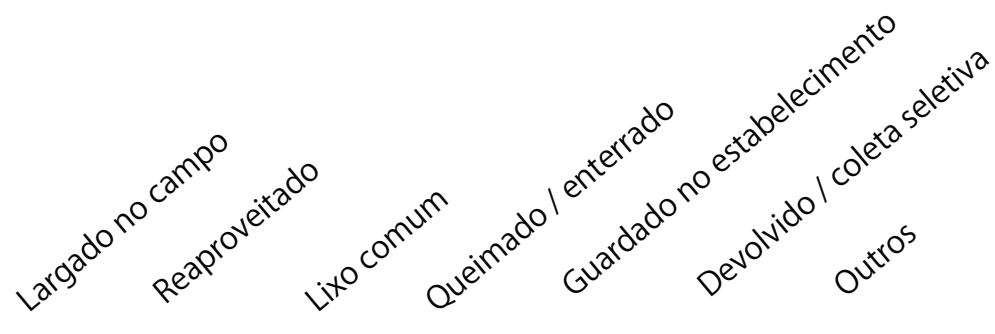

\begin{tabular}{|l|r|r|r|r|r|r|r|}
\hline Alagoas & 16,3 & 2,2 & 6,9 & 63,3 & 4,3 & 5,7 & 3,6 \\
\hline Sergipe & 12,9 & 1,5 & 11,3 & 53,6 & 5,6 & 14,5 & 3,7 \\
\hline Bahia & 12,6 & 0,7 & 5,9 & 55,7 & 9,1 & 15,2 & 3,4 \\
\hline Minas Gerais & 2,0 & 0,5 & 1,9 & 20,7 & 7,5 & 69,3 & 1,4 \\
\hline Espírito Santo & 1,0 & 1,2 & 1,8 & 12,7 & 18,9 & 67,9 & 0,9 \\
\hline Rio de Janeiro & 2,6 & 0,5 & 6,0 & 33,5 & 13,7 & 46,3 & 1,3 \\
\hline São Paulo & 0,4 & 0,6 & 1,2 & 9,6 & 15,8 & 73,8 & 1,4 \\
\hline Paraná & 0,3 & 0,3 & 0,5 & 3,3 & 13,9 & 83,6 & 0,6 \\
\hline Santa Catarina & 0,6 & 0,5 & 1,7 & 5,3 & 16,5 & 80,5 & 0,6 \\
\hline Rio Grande do Sul & 1,0 & 2,1 & 1,9 & 7,8 & 23,2 & 69,3 & 0,7 \\
\hline Mato Grosso do Sul & 0,5 & 1,0 & 1,6 & 20,1 & & 62,0 & 1,7 \\
\hline Mato Grosso & 2,1 & 2,6 & 4,2 & 29,7 & 21,6 & 40,3 & 2,3 \\
\hline Goiás & 0,7 & 0,7 & 3,5 & 29,6 & 9,7 & 56,3 & 2,2 \\
\hline Distrito Federal & 0,5 & 0,5 & 5,4 & 27,1 & 26,9 & 49,1 & 5,8 \\
\hline
\end{tabular}


Quadro 2.4 - Estudos brasileiros, entre trabalhadores rurais, que dimensionaram o destino das embalagens dos agrotóxicos

\begin{tabular}{|c|c|c|}
\hline Autor, local, ano & n. & Destino das embalagens de agrotóxicos \\
\hline $\begin{array}{l}\text { FARIA et al., Antonio } \\
\text { Prado, Ipê/RS, } 2000\end{array}$ & $\begin{array}{l}495 \text { propriedades } \\
\text { (1.479 entrevistados) }\end{array}$ & $\begin{array}{l}65 \% \text { enterravam ou queimavam, } 18 \% \text { largavam } \\
\text { no campo, } 11 \% \text { tinham depósitos específicos } \\
\text { (não existia coleta seletiva) }\end{array}$ \\
\hline $\begin{array}{l}\text { FARIA; ROSA; } \\
\text { FACCHINI, Bento } \\
\text { Gonçalves, RS, } 2009\end{array}$ & $\begin{array}{l}235 \text { propriedades } \\
\text { ( } 290 \text { entrevistados) }\end{array}$ & $\begin{array}{l}86,3 \% \text { entregavam para coleta seletiva, } 9,8 \% \\
\text { queimavam, } 11,1 \% \text { queimavam ou enterravam, } \\
3,8 \% \text { armazenavam na propriedade }\end{array}$ \\
\hline $\begin{array}{l}\text { JACOBSON et al., } \\
\text { Alto Santa Maria, ES, } \\
2009\end{array}$ & 134 propriedades & $\begin{array}{l}23,7 \% \text { enterram ou queimam, } 51,5 \% \text { devolvem } \\
\text { ao comerciante, } 22,8 \% \text { guardam na proprieda- } \\
\text { de e } 2 \% \text { jogam no rio }\end{array}$ \\
\hline $\begin{array}{l}\text { CASTRO; CONFALO- } \\
\text { NIERI, Cachoeira de } \\
\text { Macacu, RJ, } 2005\end{array}$ & 40 entrevistados & $\begin{array}{l}27,5 \% \text { queimavam, } 25 \% \text { enterravam e } 27,5 \% \\
\text { jogavam no rio }\end{array}$ \\
\hline $\begin{array}{l}\text { LIMA et al., Pelotas, } \\
\text { RS, } 2009\end{array}$ & 135 entrevistados & $\begin{array}{l}80,8 \% \text { reciclagem/coleta seletiva, } 16,2 \% \text { quei- } \\
\text { mam ou enterram e } 3 \% \text { deixam na lavoura }\end{array}$ \\
\hline $\begin{array}{l}\text { ARAÚJO; NOGUEl- } \\
\text { RA; AUGUSTO, duas } \\
\text { regiões de Pernam- } \\
\text { buco, } 2000\end{array}$ & $\begin{array}{l}\text { Entrevistados: } 27 \text { no } \\
\text { distrito de Irrigação } \\
159 \text { no Camocim de } \\
\text { São Félix }\end{array}$ & $\begin{array}{l}\text { Irrigação: } 37 \% \text { enterradas, } 18,5 \% \text { queimadas e } \\
44,5 \% \text { sem destino específico } \\
\text { Camocim: } 54,4 \% \text { deixavam no campo ou no lixo } \\
\text { comum e } 1,9 \% \text { reaproveitava }\end{array}$ \\
\hline $\begin{array}{l}\text { BEDOR et al., Vale do } \\
\text { São Francisco, } 2009\end{array}$ & 300 entrevistados & $\begin{array}{l}7 \% \text { queimadas, } 13 \% \text { retidas na propriedade, } 2 \% \\
\text { devolvidas ao comerciante e } 78 \% \text { entregues na } \\
\text { Associação de Comércio Agropecuário (local da } \\
\text { coleta seletiva) }\end{array}$ \\
\hline $\begin{array}{l}\text { RECENA; CALDAS, } \\
\text { Culturama, MS, } 2008\end{array}$ & $\begin{array}{l}40 \text { agricultores } \\
\text { (grupo focal) }\end{array}$ & $\begin{array}{l}54,4 \% \text { estocam em casa e } 8,4 \% \text { entregam ao } \\
\text { posto de recolhimento específico }\end{array}$ \\
\hline
\end{tabular}

Há também o problema das embalagens decorrentes dos biocidas veterinários e dos biocidas utilizados por desinsetizadoras urbanas e pelos serviços de saúde pública para o controle de vetores/reservatórios animais.

A Anvisa publicou uma Resolução de Diretoria Colegiada, a RDC n. 52, de 22 de outubro de 2009, que estabelece a responsabilidade das empresas aplicadoras de domissanitários inseticidas e raticidas, do comércio e das indústrias produtoras de inseticidas que também geram resíduos sólidos contaminados. 


\section{Estudos envolvendo a contaminação de mananciais}

Pessoas podem estar expostas a níveis excessivos de agrotóxicos no trabalho e por meio do alimento, do solo, da água ou do ar. E com a contaminação de águas subterrâneas, lagos, rios e outros corpos de água, os agrotóxicos podem ainda poluir os suprimentos de água potável, peixes e outras fontes muitas vezes vitais para o bem-estar humano.

Nos últimos anos, estudos brasileiros têm documentado a contaminação de mananciais hídricos por vários tipos de agrotóxicos. Um desses estudos monitorou a ocorrência de agrotóxicos em águas superficiais de sete regiões do sul do Brasil associadas ao cultivo de arroz irrigado em três épocas, na safra 2007-2008: antes do período de cultivo, durante o cultivo e logo após a drenagem da água das lavouras para colheita. As amostras de águas superficiais foram coletadas em três locais por região, totalizando 21 locais. Usando cromatografia líquida e espectrometria de massa, foram avaliados os seguintes agrotóxicos: clomazone, quinclorac, penoxsulam, imazethapyr, imazapic, carbofuran, 3-hydroxy-carbofuran, fipronil e tebuconazole. Imazethapyr, carbofuran e fipronil foram detectados em todas as regiões estudadas. O fipronil foi encontrado em todas as épocas avaliadas, provavelmente devido à sua longa meia-vida no solo (de 123 até 600 dias). O mesmo ocorreu com tebuconazole, mas por razão diferente: maior facilidade de ser transportado para águas superficiais, associado ao sedimento ou dissolvido na água (índice de GOSS). Foi detectado maior número de agrotóxicos nas regiões da depressão central e na planície costeira externa à Lagoa dos Patos: oito dos nove agrotóxicos estudados. A Região Sul apresentou a menor contaminação, com apenas quatro agrotóxicos detectados. Todas as amostras em todas as épocas continham ao menos um agrotóxico em nível detectável (SILVA et al., 2009).

Outro estudo, realizado na Zona da Mata de Minas Gerais, avaliou os agrotóxicos mais usados na cultura do café em águas superficiais do município de Manhuaçu. Foram identificados os principais tipos químicos usados na região. Um dos objetivos era desenvolver metodologia de identificação dos agrotóxicos que apresentam maior risco de contaminação das águas na região cafeicultora. Os dez agrotóxicos com maior consumo anual e maior potencial de contaminação da água de superfície foram: flutriafol, clorpirifós, triadimenol, ciproconazol, tiametoxan, tiofanato-metila, atrazina, imidacloprido, tebuconazol e diuron. Visando a validar a metodologia de identificação de agrotóxicos com alto risco de contaminação, três produtos com maior consumo anual e maior risco de contaminação das águas de superfície foram analisados e confirmados nos exames laboratoriais de amostras de água: atrazina, flutriafol e epoxiconazol (SOARES et al., 2012).

Estudos demonstraram ainda a contaminação da água por agrotóxicos como carbofurano, clomazona, quincloraque, bentazona, 2,4-D, fipronil e propanil em áreas de cultivo de arroz (MARCHESAN et al., 2007, 2010; GRÜTZMACHER et al., 2008) e 
imidacloprido, atrazina e clomazona em áreas de cultivo de fumo (BORTOLUZZI et al., 2006) no Rio Grande do Sul; coral, diiston, fosdrin e malation próximo à cultura canavieira no rio Paraíba do Sul, em Minas Gerais, (CAPOBIANGO; CARDEAL, 2005); e diversos agrotóxicos no Mato Grosso (PIGNATI; MACHADO; CABRAL, 2007) e no Ceará (MARINHO, 2010).

Mais recentemente, grupos de pesquisadores de universidades brasileiras têm estudado as implicações socioambientais dos agrotóxicos em territórios de desenvolvimento humano. Na Chapada do Apodi, o Núcleo Tramas e a Universidade Federal do Ceará realizaram uma pesquisa em profundidade; em Lucas do Rio Verde (MT), pesquisadores da Universidade Federal de Mato Grosso (UFMT) analisam os impactos do agronegócio; a fruticultura para exportação da região do submédio do Rio São Francisco tem sido estudada no Centro de Pesquisas Aggeu Magalhães (PE) e na Universidade Federal do Vale do São Francisco, e o uso dos agrotóxicos para o controle de endemias tem sido objeto de estudo também no Centro de Pesquisas Aggeu Magalhães.

\section{O caso da Chapada do Apodi, CE}

A ocupação de extensas áreas por monoculturas, uma das principais características do modo de produção do agronegócio, é responsável pelo desequilíbrio ecológico em territórios brasileiros. As altas taxas de produtividade por hectare, baseadas em regimes intensivos de adubação e irrigação, repercutem na perda de biomassa dos biomas, com redução da cobertura vegetal nativa e consequente desequilíbrio dos ciclos biogeoquímicos, condições climáticas e perda da sociobiodiversidade.

O monocultivo da banana na Chapada do Apodi, assim como em outras regiões, enfrenta o problema da sigatoka amarela, doença endêmica causada pelo fungo $\mathrm{My}$ cosphaerella musicola, Leach, que, ao infectar as folhas, provoca sua morte prematura, ocasionando a diminuição do fruto e perdas de até $50 \%$ na produção. Na tentativa de controlar a doença, a aplicação de fungicidas tem sido prática frequente das empresas nacionais e transnacionais instaladas na região, sendo a pulverização aérea considerada pelos empresários o método mais vantajoso de combate ao fungo.

Nos 2.950 hectares destinados ao cultivo da banana, tem-se, aproximadamente, o lançamento de 73.750 litros de calda tóxica a cada pulverização. Como eram realizadas no mínimo seis pulverizações durante a quadra chuvosa, estima-se um lançamento anual de 442.500 litros de calda tóxica no meio ambiente (MARINHO; CARNEIRO; ALMEIDA, 2011). O quadro 2.5 demonstra a classificação toxicológica e ambiental dos ingredientes ativos utilizados na pulverização aérea.

Ressalta-se a inoperância e deficiência das instituições públicas responsáveis por, no uso de suas atribuições legais, garantir o cumprimento das leis e normas que dizem respeito ao "uso seguro" dos agrotóxicos na região. Exemplo disso é o descumprimento da Instrução Normativa n. 2, de 3 de janeiro de 2008, estabelecida pelo MAPA, que define 
a distância mínima de quinhentos metros de povoações, cidades, vilas e bairros para a prática da pulverização aérea. A figura 2.9 evidencia a proximidade entre as residências e as áreas de cultivo de banana, caracterizando uma situação de contiguidade.

Quadro 2.5 - Ingredientes ativos utilizados na pulverização aérea na Chapada do Apodi e sua classificação toxicológica e ambiental

\begin{tabular}{|l|l|l|}
\hline Agrotóxicos/grupo químico & Classe toxicológica & Classe ambiental \\
\hline $\begin{array}{l}\text { Difenoconazol / Triazol } \\
\text { Score }\end{array}$ & I - Extremamente Tóxico & $\begin{array}{l}\text { II - Muito Perigoso e Altamente } \\
\text { Persistente no Meio Ambiente }\end{array}$ \\
\hline $\begin{array}{l}\text { Epoxiconazol e Piraclostro- } \\
\text { bina /Triazol e Strobilurina } \\
\text { Opera }\end{array}$ & II - Muito Tóxico & $\begin{array}{l}\text { II - Muito Perigoso e Altamente } \\
\text { Persistente no Meio Ambiente }\end{array}$ \\
\hline Piraclostrobina / Comet & II - Muito Tóxico & $\begin{array}{l}\text { II - Muito Perigoso e Altamente } \\
\text { Persistente no Meio Ambiente }\end{array}$ \\
\hline
\end{tabular}

Fonte: MARINHO; CARNEIRO; ALMEIDA (2011).

O lançamento dos agrotóxicos por via aérea atinge comunidades fora das áreas de plantação e é responsável pelas frequentes queixas relacionadas aos incômodos de saúde logo após a aplicação, mesmo quando são seguidas as regras da aviação para esse fim. Os principais sintomas percebidos são "característicos da exposição a venenos, principalmente cefaleias, vômitos, náuseas e alergias, além de relatos sobre a morte de animais sempre que a 'chuva de venenos' acontece" (MARINHO; CARNEIRO; ALMEIDA, 2011, p. 170).

Mesmo diante dessas evidências, os empresários, como ressalta Teixeira (2010), apresentam esse procedimento como seguro, argumentando que usam tecnologias avançadas, incluindo o uso de GPS, monitoramento constante e fiscalização.

O problema da pulverização aérea torna-se ainda mais grave devido à grande quantidade de veneno que penetra no ambiente por diferentes vias. Mesmo em condições ideais e como total controle sobre fatores como temperatura, calibração e ventos, normalmente ocorre uma "deriva técnica". Segundo a autora, apenas 32\% dos agrotóxicos pulverizados permanecem nas plantas. O restante vai para o solo (49\%) ou para áreas circunvizinhas através do ar (19\%) (RIGOTTO, 2013).

Em relação à contaminação do ambiente de trabalho, Pignati alerta para a intencionalidade inerente ao manuseio e à aplicação dos agrotóxicos nas plantações. Segundo o autor, "com a finalidade de combater as pragas da lavoura, o homem contamina intencionalmente o local de trabalho, que é o próprio ambiente agrícola, atingindo em maior ou menor intensidade os trabalhadores, a produção e o ambiente" (PIGNATI; MACHADO; CABRAL, 2007, P. 106). 


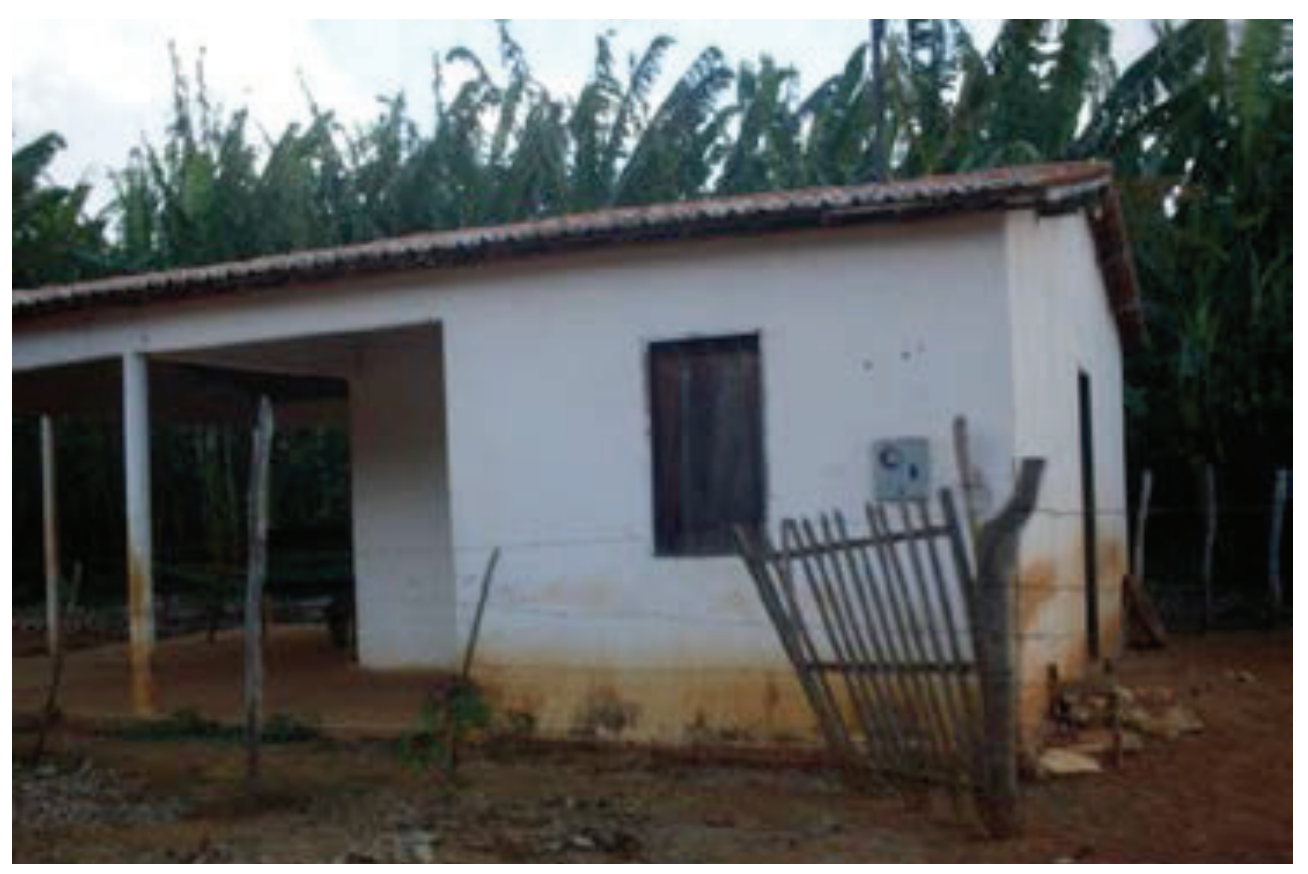

A preocupação e o incômodo da população residente na Chapada do Apodi levaram a uma série de lutas, inclusive pela proibição da pulverização aérea. Fruto desse processo, no dia 8 de outubro de 2009 foi aprovada a Lei Municipal n. 1.478/09, que proíbe a pulverização aérea. Porém, apesar da intensa organização popular, a legislação vigente não foi suficiente para conter a força do capital. Apenas três meses após a aprovação da referida lei, o prefeito de Limoeiro do Norte propôs à Câmara Municipal sua revogação.

Conclui-se que a contaminação ambiental é uma decorrência da estratégia de expropriação das terras adotada pelo agronegócio como forma de expulsar os camponeses de suas terras. Foi o caso da Comunidade do Km 69, apresentado por Lima, Vasconcelos e Freitas (2011). De acordo com os autores, essa comunidade quase foi destruída em decorrência do cruel artifício adotado pelas empresas de espalhar enxofre na direção das comunidades. Como corolário, grande parte das famílias foi obrigada a vender suas terras por um preço irrisório ao agronegócio, ou mesmo a abandoná-las devido aos frequentes problemas de saúde ocasionados pelo contato com essa substância tóxica (MARINHO, 2010). 


\section{O caso de Lucas do Rio Verde, MT}

No Mato Grosso, palco principal do agronegócio brasileiro, das monoculturas, das plantas transgênicas e de uso intensivo de agrotóxicos, os efeitos da pulverização aérea, da contaminação das águas e do leite materno também foram objeto da avaliação da contaminação de anfíbios por exposição ambiental aos agrotóxicos.

Foi analisado o plasma sanguíneo de 14 sapos-cururu (Rhinella schneideri) e 22 rãs-pimenta (Leptodactylus labyrinthicus), em dois córregos (Cedro e Xixi) do município de Lucas do Rio Verde. Resíduos de endosulfan e de outros organoclorados foram detectados por cromatografia gasosa no plasma sanguíneo de sete sapos (35\% da amostra analisada), de 11 rãs ( $50 \%$ da amostra analisada). Nos sedimentos dos córregos foi detectada a presença de resíduos de endosulfan $\alpha, \beta$ e S $(0,38$ a $0,93 \mu \mathrm{g} / \mathrm{kg})$, flutriafol $(0,25$ a $0,49 \mu \mathrm{g} / \mathrm{kg})$ e atrazina $(0,18$ a $0,26 \mu \mathrm{g} / \mathrm{kg})$. Foram detectadas más-formações apendiculares em cinco indivíduos, ou $22 \%$ dos sapos coletados, enquanto que nos sapos da lagoa-controle observaram-se apenas $6 \%$ de más-formações congênitas, conforme a figura 2.10 (MOREIRA et al., 2010).

A incidência de agravos correlacionados aos processos produtivos do agronegócio em Lucas do Rio Verde, como acidentes de trabalho, intoxicações agudas por agrotóxicos, neoplasias, más-formações congênitas e agravos respiratórios, aumentou entre $40 \%$ e $102 \%$ nos últimos dez anos, com linha de tendência com $50 \%$ acima da incidência anual estadual destes anos. Além disso, os indicadores e incidência desses agravos estavam diretamente correlacionados com a produção agrícola temporária (soja, milho e algodão) e a exposição aos agrotóxicos usados nessas lavouras (MOREIRA et al., 2010; CUNHA, 2010; FÁVERO, 2011; PIGNATI; MACHADO, 2011; UEKER, 2012; CURVO, 2012; OLIVEIRA, 2012).
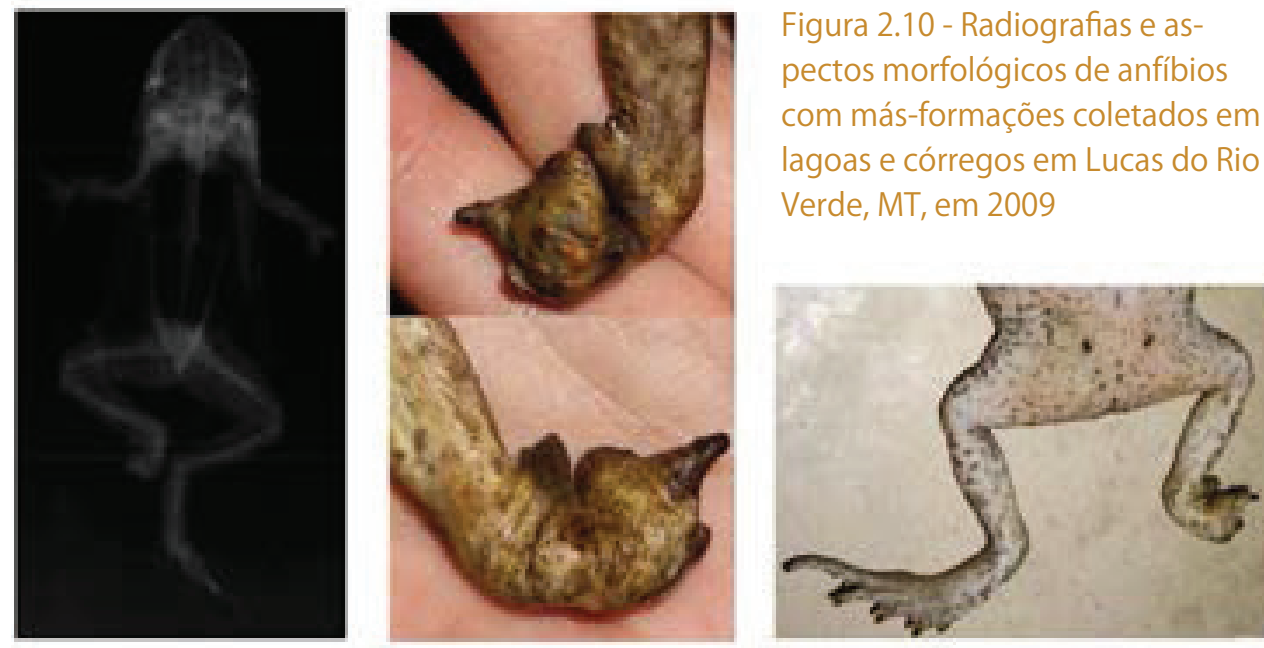

Figura 2.10 - Radiografias e aspectos morfológicos de anfíbios com más-formações coletados em lagoas e córregos em Lucas do Rio Verde, MT, em 2009

Fontes: MOREIRA et al. (2010); RODRIGUES et al. (2009). 
Essa situação sociossanitária crítica foi apresentada às autoridades da saúde, da agricultura, da educação, da Câmara Municipal, aos sindicatos rural patronal e dos trabalhadores rurais, e ao Ministério Público Estadual (MPE) em duas audiências públicas do município realizadas em 2010 e 2011. Nesses eventos foram sugeridas várias medidas de mitigação dos danos ambientais e à saúde, assim como de prevenção contra os riscos dos processos produtivos do agronegócio.

Nesse processo de pesquisa-ação, lideranças populares e alguns pesquisadores foram "pressionados" por gestores públicos e por fazendeiros do agronegócio para que recuassem das pesquisas, denúncias e ações populares. Porém, vários afetados resolveram caminhar, com apoio da academia e dos movimentos organizados, na busca do desenvolvimento sustentável; instituições acadêmicas e de pesquisa, inclusive a Associação Brasileira de Saúde Coletiva, a Abrasco, têm oferecido seu apoio.

O movimento continuou, e em 2012 avaliou-se que houve poucos avanços na mitigação/prevenção dos danos/riscos - por exemplo, não se cumpriu a determinação de manter a distância de trezentos metros entre as residências e as margens dos córregos e as pulverizações - explicitados em Termo de Ajuste de Conduta (TAC/MPE) que os fazendeiros do agronegócio de Lucas do Rio Verde se recusam a assinar e cumprir. Ainda tramitam na Justiça criminal vários processos em que chacareiros cobram indenizações pelos danos às hortaliças e pela poluição de suas águas por agrotóxicos.

Segundo levantamento de Nasrala Neto (2012) e Ferreira (2012), até julho de 2011 a Secretaria de Saúde de Lucas do Rio Verde ainda não havia implantado a vigilância à saúde dos trabalhadores rurais e urbanos e a vigilância à saúde ambiental se resumia ao controle de vetores de doenças endêmicas (dengue, malária e leishmaniose) e de coliformes na água potável. Esses autores relatam também que a vigilância ambiental e de qualidade dos alimentos da Secretaria de Agricultura do município e do Instituto de Defesa Agropecuária do Estado de Mato Grosso (Indea-MT) continuam se resumindo ao treinamento para o "uso seguro" de agrotóxicos, ao recolhimento de embalagens vazias e a precária fiscalização das leis e normas de prevenção dos riscos dos agrotóxicos para a saúde, os alimentos e o ambiente.

Esse tipo de processo produtivo, ou a máxima exploração da natureza a curto prazo para produzir cereais, algodão e cana, ou commodities (mercadorias) agropecuárias, que exerce impactos negativos na saúde e no ambiente, executado em Lucas do Rio Verde, está presente em 62 dos 141 municípios de Mato Grosso e em milhares de municípios do interior do Brasil. Nesses espaços é necessário que a sociedade organizada faça reflexões sobre um modelo sustentável de desenvolvimento, o qual envolva democracia, equidade, saúde e preservação ambiental e viabilize a transição agroecológica para a agropecuária brasileira. 


\section{O caso do Pantanal Mato-grossense}

Nas áreas de cultivo de soja, cana-de-açúcar, algodão e milho na região do planalto mato-grossense nasce o rio Paraguai, e em seus afluentes que circundam a planície pantaneira, bem como nas áreas de arroz irrigado na própria planície úmida (bacia do rio Miranda, afluente do rio Paraguai), o uso intensivo de agrotóxicos nessas culturas está contaminando esses rios formadores de uma das maiores áreas úmidas do mundo ainda conservadas, o Pantanal Mato-grossense.

Amostras de sedimentos dos principais tributários do rio Paraguai (rios Jauru, Paraguai, Cuiabá, São Lourenço, Vermelho, Itiquira, Correntes, Taquari, Coxim, Negro, Aquidauana e Miranda) foram coletadas em 25 pontos amostrais na desembocadura desses rios. Também foram coletadas em 25 pontos nas áreas úmidas de planície, em remansos e em canais de irrigação de lavouras de arroz da bacia do rio Miranda (afluente do rio Paraguai) (DORES et al., 2008; MIRANDA et al., 2008).

As amostras coletadas, acondicionadas em frascos de alumínio, foram congeladas até o momento da análise no Laboratório de Análise de Resíduos de Biocidas da UFMT. As coletas ocorreram durante o ano de 2005 na fase de seca (maio) e no início do período de chuvas (dezembro), quando os agrotóxicos, nutrientes e solos são escoados para dentro dos rios com as primeiras enxurradas. Ao todo, 32 princípios ativos foram analisados, sendo nove herbicidas e 23 inseticidas, por apresentarem uso mais frequente nessa bacia e por serem passíveis de análise por cromatografia gasosa e espectrometria de massa, incluindo os organoclorados persistentes (DORES et al., 2008; MIRANDA et al., 2008).

Os compostos detectados nos sedimentos da bacia o rio Miranda, nas áreas úmidas de produção de arroz, foram: piretroide (l-cialotrina), de baixa persistência, mas de alta toxicidade para peixes e invertebrados aquáticos (córrego Cachoeirão, rios Aquidauana e Miranda); dieldrin e p,p’ DDE (metabolito do DDT) em 100\% das amostras (1,2 a 14,4 $\mathrm{mg} / \mathrm{kg})$; e o p,p' DDT (1,0 mg/kg), persistente e de uso proibido, encontrado no rio Miranda e em um canal de irrigação de rizicultura em valor elevado. Os três últimos foram detectados em valores acima dos limites da Resolução Conama 344/04, o que implica alto potencial de efeitos adversos à biota (DORES et al., 2008; MIRANDA et al., 2008).

Os compostos detectados nos sedimentos da bacia do rio Paraguai, nas desembocaduras de seus afluentes que nascem no planalto dentro das culturas de soja, milho, algodão e cana, foram: piretroides (permitrina de 1,0 a 7,0 $\mu \mathrm{g} / \mathrm{Kg}$, em cinco pontos e 1-Cialotrina de 1,0 a $5,0 \mu \mathrm{g} / \mathrm{Kg}$ em três pontos, deltametrina de $20,0 \mu \mathrm{g} / \mathrm{Kg}$ em um ponto) e pp'-DDT de $3,2 \mu \mathrm{g} / \mathrm{Kg}$ em um ponto, persistente e de uso proibido. Os piretroides foram detectados em valores acima dos limites da Resolução Conama 344/04, e o DDT, apesar proibido no Brasil desde 1985, foi encontrado. Como a concentração do DDT está muito abaixo do DDE, isto pode representar contaminação persistente antiga. Esses dados indicam alto potencial de efeitos adversos à biota pantaneira (DORES et al., 2008; MIRANDA et al., 2008). 
A detecção de resíduos de agrotóxicos no planalto mato-grossense, onde nascem os rios e afluentes do rio Paraguai, e na planície pantaneira (pantanal) é preocupante. Em termos ecológicos, o efeito crônico da contaminação, mesmo em baixas concentrações, implica efeitos sobre a saúde e o ambiente a médio e a longo prazos, como a diminuição do potencial biológico de espécies animais (diminuição do sucesso reprodutivo dos peixes, por exemplo) e vegetais. Também haverá impactos na saúde humana, como o aumento da incidência de cânceres, más-formações fetais, distúrbios neurológicos e hormonais e outros efeitos crônicos, na população pantaneira e de todos os que vivem na bacia do pantanal mato-grossense (DORES et al., 2008; MIRANDA et al., 2008).

\section{caso do Polo Fruticultor de Exportação de Petrolina, PE $^{9}$}

No Nordeste brasileiro, a ênfase das ações governamentais na modernização da agricultura consistiu no incentivo à irrigação nas áreas semiáridas, dando continuidade à antiga política das águas, iniciada no final do século XIX. Com os objetivos de transformar um espaço árido em terras cultiváveis, de converter a economia da produção agrícola tradicional (de sequeiro) em um setor produtivo de base capitalista moderna e de criar mentalidade empresarial para os produtores rurais na região.

Mediante a dinâmica da política da seca, a região moderna, irrigada (um oásis), do Semiárido se desenvolve à custa da manutenção do subdesenvolvimento das áreas rurais de sequeiro. A situação, dentro da região semiárida, é de reprodução local do processo global, e deve ser entendida dentro do contexto global. Enquanto a região moderna, irrigada, central, produz para os mercados local, nacional e internacional, a área de sequeiro, subdesenvolvida, periférica, provê para o polo exportador o suprimento de uma mão de obra barata, o que torna lucrativa a exportação das colheitas (ABRAMOVAY, 2002).

Uma das áreas indicadas para a implantação da fruticultura irrigada foi a microrregião de Petrolina/Juazeiro, localizada entre os estados de Pernambuco e Bahia e situada no submédio do Vale do São Francisco. Com cerca de 120 mil hectares irrigados, tendo como principais monoculturas as fruteiras irrigadas de manga e uva, essa região constitui, atualmente, uma das principais áreas de exploração e exportação da hortifruticultura irrigada do país, com mais de $51 \%$ da sua população economicamente ativa empregada na agricultura (RIGOTTO; AUGUSTO, 2007).

A cidade de Petrolina, um dos principais centros do submédio, fundada em 1893, fica a 756 quilômetros da capital de Pernambuco, Recife, possuindo uma área urbana de $4.558,54 \mathrm{~km}^{2}$ com uma população de 218.538 habitantes, segundo o Censo Demográfico do IBGE de 2000 (AUGUSTO; FLORÊNCIO; CÂMERA NETO, 2005).

${ }^{9}$ Estudo das cadeias produtivas do estado de Pernambuco, publicado em AUGUSTO (2010). 
A agricultura irrigada na região engloba uma ampla cadeia produtiva, com diversos atores e processos, voltada principalmente para a exportação. A dependência do mercado externo, com suas exigências comerciais, traz efeitos relevantes para a produção local e, consequentemente, para as condições de saúde dos trabalhadores.

Nessa cadeia, objetivando atender às referidas demandas comerciais, produtores independentes se organizam em cooperativas e outras associações, para utilizar os serviços de packing house (local específico de processamento - classificação, embalagem e expedição - das frutas) ou para vender suas culturas aos grandes grupos produtores. Estes últimos também têm sua própria produção, que, mesmo visando ao mercado externo, abastecem também os mercados nacional e local.

Aos colonos (agricultores que cultivam suas próprias culturas) resta negociar sua produção com os atravessadores (comerciantes responsáveis pela compra e venda de produtos) que mantêm o mercado local e alguma parcela do mercado nacional.

Para a análise das condições de vida dos trabalhadores rurais da região, consideramos que o agronegócio em Petrolina é o vetor do desenvolvimento econômico da região e responsável pelos diversos condicionantes de risco para a saúde do trabalhador local.

O estudo de Bedor (2008) observou expressivo número se casos de intoxicação por agrotóxicos na região da fruticultura em Petrolina (RAMOS; SANTOS; BEDOR, 2007; RIBEIRO, 2006; PETROLINA, 2007; BRASIL. CNSAN, 2007; COSTA; NEVES, 2006), uso abusivo de álcool e de outras drogas (BRASIL. CNSAN, 2007), assim como lesões por esforço repetitivo (LER) e distúrbios osteomusculares relacionados ao trabalho (Dort) (RAMOS; SANTOS; BEDOR, 2007; BEDOR et al., 2007), que foram relacionados com as precárias condições de trabalho. Tal precariedade se expressa em casos de desrespeito aos direitos humanos e trabalhistas (COSTA; NEVES, 2006; BEDOR et al., 2007); exposição a condições inseguras no trabalho (BEDOR et al., 2007); exposição aos agrotóxicos (BEDOR et al., 2007; CAVALCANTI; BENDINI; GRAZIANO, 1999; PETROLINA, 2007); discriminação de gênero no ambiente de trabalho; falta de segurança no trabalho (PEREIRA; NAIRÓ, 2006) e baixos salários (BEDOR et al., 2007; CAVALCANTI; BENDINI; GRAZIANO, 1999; PEREIRA; NAIRÓ, 2006).

Ao mesmo tempo, pode-se observar como condições de vida, na zona rural de Petrolina, reduzido acesso ao sistema de saúde (AUGUSTO; CARNEIRO; FLORÊNCIO, 2005; PETROLINA, 2007; XAVIER, 2006), reduzido acesso a tratamento e abastecimento da água e precário destino do lixo (AUGUSTO; CARNEIRO; FLORÊNCIO, 2005), apesar do expressivo acesso ao esgotamento sanitário (PETROLINA, 2007), além de exposição ao abuso e à exploração sexual (BEDOR et al., 2007) e alto índice de analfabetismo (CAVALCANTI; BENDINI; GRAZIANO, 1999). Por outro lado, observa-se que boa parte da população tem casa de tijolo e acesso à energia elétrica (AUGUSTO; CARNEIRO; FLORÊNCIO, 2005).

Segundo Pereira e Nairó (2006), a cidade de Petrolina está inserida na região demarcada pelo IBGE como baixo Índice de Desenvolvimento Humano (IDH), fator 
que, associado à falta de oportunidades de trabalho, contribui para a marginalização das populações urbanas e rurais da região.

Quanto aos impactos da irrigação no desenvolvimento social de Petrolina, destaca-se que essa prática promove, direta ou indiretamente, iniquidades no acesso ao solo (IBGE, 2007) e aos meios de produção/financiamento (BEDOR et al., 2007; BOMFIM, 1999) favorecendo a intensa imigração e, consequentemente, o aumento populacional rápido da região (FETAPE, 2007), ampliando assim a vulnerabilidade social (MARTINS, 1993).

A agricultura irrigada provocou na região uma ruptura com as práticas tradicionais de produção para subsistência, mas também o incremento da área irrigada, a elevação da base técnica da produção, a instalação de grandes empresas agroindustriais, a inserção de famílias e de assentados em áreas de projetos de reforma agrária na agricultura irrigada e empresarial. Não há dúvida de que houve profundas transformações na região. O que precisa ser avaliado é se de fato houve melhoria das condições de vida, sob a égide de um desenvolvimento humano, ambientalmente justo (ABRAMOVAY, 2002).

Sabe-se que a implantação dos projetos privados de irrigação ampliou a disputa no mercado de terras, do qual a população local perdeu o controle, dadas as constantes variações por que passavam os preços das terras em um curto período.

A exportação tem sido responsável pela produção centrada na monocultura de manga e uva (CARVALHO; MIRANDA, s.d.) com produção dirigida para as "janelas de mercado" (PASSINI; CARVALHO, 2000), o que reflete a dependência ao mercado externo. Uma profunda mudança demográfica e de ocupação do solo ocorreu nos dois municípios de abrangência do polo fruticultor: Petrolina e Juazeiro. Enquanto o primeiro apresenta indicadores favoráveis de desenvolvimento, o segundo fica com o ônus desse processo, instaurando-se na região uma grande desigualdade intrarregional.

Como, geralmente, a produção é de monocultura, as áreas de cultivo estão sempre propensas ao ataque de pragas. A aplicação de um grande volume de fertilizantes e agrotóxicos compromete os solos e agrava os riscos de contaminação das águas, aumentando a vulnerabilidade humana de exposição a esses produtos tóxicos para a saúde, e se torna, assim, um grande fator de insustentabilidade.

A fruticultura estabelecida no Semiárido tem contribuído para o avanço da desertificação. Assim, às limitações da natureza aliam-se as ações antrópicas, colocando em dúvida o caráter de sustentabilidade que essa economia poderia alcançar.

Ao mesmo tempo, o estabelecimento de novos contratos de uso da terra (PASSINI; CARVALHO, 2000), a estratificação dos produtores (COSTA; NEVES, 2006), precarização das condições de trabalho (MINAS GERAIS, 2003; COSTA; NEVES, 2006) e o favorecimento da comercialização indevida de agrotóxicos (PETROLINA, 2007; PEREIRA; NAIRÓ, 2006) exercem expressivo impacto no ambiente e na saúde da população.

Na região submédia do Vale do São Francisco, o empresariado opta por empregar a mão de obra feminina na fruticultura, por considerá-la mais criteriosa, delicada e pro- 
dutiva que a masculina. Há um processo de sobre-exploração das mulheres no processo produtivo, especialmente em tarefas mais penosas. Essa situação afeta a saúde mental masculina. A questão de gênero precisa ser mais bem observada nesse contexto.

A entrada de produtos, principalmente in natura, no mercado internacional depende de certificações. Os países da União Europeia, maiores importadores de frutas, utilizam principalmente a certificação EurepGap. Esse pode ser um caminho para melhor as condições de trabalho e os cuidados para com o ambiente e a saúde da população. Estabelecer uma aliança estratégica entre os interesses de mercado para uma produção limpa e socialmente justa parece uma boa oportunidade de melhorar as condições de vida nessa cadeia produtiva.

A técnica de irrigação tem por finalidade aplicar água no solo, visando a atender às exigências hídricas do sistema planta-atmosfera, proporcionando umidade adequada ao desenvolvimento normal das plantas, suprindo a falta, a insuficiência ou a má distribuição das chuvas (EMBRAPA, s.d.). Nesse modelo tecnológico de produção, há uma série de práticas agronômicas vitais para o aumento e a manutenção da produção, como adubação intensiva do solo e controle de pragas e doenças dos plantios, que com a irrigação são mais frequentes (CODEVASF, 2007).

A esses aspectos tecnológicos se sobrepõem aqueles relacionados com as condições climáticas de altas temperaturas da região, que são favorecedoras das pragas e doenças vegetais em situações de desequilíbrio ecológico. O regime de chuvas escasso e irregular do Semiárido é um importante elemento do sistema ecológico da região. Todos esses aspectos contraindicam a ocupação dessa área com o modelo de agricultura irrigada. Para compensar essas adversidades, é imposto o consumo de insumos químicos para fertilização e para o combate a pragas.

Os agrotóxicos são intensamente utilizados para assegurar os padrões de produtividade esperados pelo mercado consumidor. A escolha do Semiárido para a produção de uva e manga se deu em função da escassez de água pluvial e da existência de um rio que possibilita o fornecimento de água para irrigação. Enquanto os produtores rezam para não chover, a população reza ao contrário, fazendo suas novenas para São José na esperança das chuvas. No modelo agrícola irrigado da monocultura de frutas (uva e manga) a quantidade de água é regulada e o fenômeno da chuva "atrapalha" a produção, pois a chuva, fenômeno da natureza, não se sujeita ao controle tecnológico na escala desejada.

Os impactos ambientais decorrentes da irrigação e dos insumos químicos são diversos. As características dos solos nessa região propiciam a lixiviação dos produtos químicos para camadas mais profundas, favorecendo contaminação subterrânea que atinge o lençol freático e as águas superficiais de rios e açudes. E nesse contexto de desenvolvimento forçado de uma região tropical climaticamente vulnerável, muito desfavorável o modelo tecnológico adotado, o uso de agrotóxicos é a via escolhida para o controle de pragas.

Diante da constatação de que a população, principalmente os trabalhadores da fruticultura do submédio do Vale do São Francisco, está exposta aos agrotóxicos utilizados 
intensiva e continuamente, é fundamental identificar se os produtos utilizados têm potencial carcinogênico, assim como fazer a vigilância da ocorrência de câncer nessa população com base em um modelo mais preditivo, de utilidade para a vigilância da saúde. Em se tratando de câncer, não basta para a saúde pública contabilizar casos e mortes, é necessário antecipar as ações tendo em vista a prevenção precoce, mediante o controle da exposição e de efeito epigenéticos, anteriores aos quadros de doença.

Foram levantados $108 \mathrm{di}$ ferentes nomes de agrotóxicos comercializados na região, classificados em 71 ingredientes ativos e oito misturas. A classificação quanto a classe, grupo químico e classificação toxicológica e ambiental dos agrotóxicos pode ser vista na tabela 2.1.

$\mathrm{Na}$ classificação toxicológica, apenas 19\% dos agrotóxicos aparecem como pouco tóxicos para o homem, os restantes $81 \%$ são de produtos extremamente, altamente e medianamente tóxicos. Além disso, $44 \%$ desses compostos são muito perigosos para o meio ambiente. De acordo com Garcia, Bussacos e Fischer (2005), no Brasil essas classificações são meramente figurativas, pois para os seres humanos não há diferença entre um produto extremamente tóxico e outro pouco tóxico, quando qualquer um deles pode ser comercializado e utilizado da mesma forma, por qualquer usuário, em quantidades ilimitadas.

Dos agrotóxicos mais citados (quadro 2.6), 77\% são potencialmente carcinógenos e $31 \%$ potencialmente pré-carcinógenos, incluindo o Folisuper, o mais utilizado na região. 
Quadro 2.6 - Ingredientes ativos mais utilizados no Vale do São Francisco e suas fórmulas químicas

\begin{tabular}{|l|l|}
\hline Substâncias & Fórmula estrutural \\
\hline Abamectina & $\mathrm{C}_{14} \mathrm{H}_{18} \mathrm{ClN}_{3} \mathrm{O}^{4}$ \\
\hline Metamidofós (metom) & $\mathrm{C}_{2} \mathrm{H}_{8} \mathrm{NO}_{2} \mathrm{P}$ \\
\hline Parationa-metílica (Pme) & $\mathrm{C}_{8} \mathrm{H}_{10} \mathrm{NO}_{3} \mathrm{OS}$ \\
\hline Cimoxanil (cim) & $\mathrm{C}_{7} \mathrm{H}_{10} \mathrm{~N}_{4} \mathrm{O}_{3}$ \\
\hline Difenoconazol (dif) & $\mathrm{C}_{19} \mathrm{H}_{17} \mathrm{Cl}_{2} \mathrm{O}_{3}$ \\
\hline Famoxadona (fam) & $\mathrm{C}_{22} \mathrm{H}_{18} \mathrm{~N}_{2} \mathrm{O}_{4}$ \\
\hline Lambda - cialotrina (L cia) & $\mathrm{C}_{23} \mathrm{H}_{19} \mathrm{ClF}_{3} \mathrm{NO}_{3}$ \\
\hline Azoxistrobina (azox) & $\mathrm{C}_{22} \mathrm{H}_{17} \mathrm{~N}_{3} \mathrm{O}_{5}$ \\
\hline Paclobutrazol (paclo) & $\mathrm{C}_{15} \mathrm{H}_{20} \mathrm{ClN}_{3} \mathrm{O}$ \\
\hline Fenarimol (fenar) & $\mathrm{C}_{17} \mathrm{H}_{12} \mathrm{ClN}_{20}$ \\
\hline Carbosulfano (car) & $\mathrm{C}_{20} \mathrm{H}_{32} \mathrm{~N}_{2} \mathrm{O}_{3} \mathrm{~S}$ \\
\hline Tebuconazol (tebuc) & $\mathrm{C}_{16} \mathrm{H}_{22} \mathrm{ClN}_{3} \mathrm{O}$ \\
\hline Cianamida (cian) & $\mathrm{CH}_{2} \mathrm{~N}_{2}$ \\
\hline
\end{tabular}

Foi observado que $23 \%$ dos trabalhadores rurais não possuem orientação para a compra dos agrotóxicos, o que é uma importante vulnerabilidade. $21 \%$ dos produtos indicados por vendedores não são tecnicamente liberados para os cultivos, conforme prescrição do MAPA. Os vendedores não estão devidamente preparados para orientação na utilização desses produtos tóxicos.

Este fato contraria a legislação, que no Brasil obriga o receituário agronômico fornecido por profissionais legalmente habilitados (engenheiros agrônomos) (BEDOR et al., 2007) 78\% dos agricultores informaram não utilizar o receituário na hora da compra.

A pulverização costal de agrotóxicos nas plantações é utilizada em $32 \%$ das propriedades, e em $20 \%$ a tração animal é utilizada para apoiar essa prática.Nesse contexto está a se desenvolver o megaprojeto de transposição do rio São Francisco, que na verdade pode ser interpretado de duas formas: como um projeto "fantasia" ou como um projeto "real" (COSTA; NEVES, 2006). Ao projeto fantasia (da retórica), no qual 12 milhões de pessoas seriam beneficiadas, trezentos mil hectares seriam irrigados, um milhão de empregos seriam gerados e que seria a solução definitiva para o problema da seca, contrapõe-se o projeto real (o que está escrito no licenciamento ambiental), no qual apenas $5 \%$ do território Semiárido brasileiro e $0,3 \%$ da população serão be- 
neficiados, apenas $4 \%$ da água serão destinados à chamada população difusa, $26 \%$ ao uso urbano e industrial e $70 \%$ à irrigação da agricultura. Deve-se considerar ainda que entre os usos econômicos da água estão previstos irrigação, carcinicultura, floricultura e o polo industrial de Pecém (CE), de siderurgia e metalurgia para exportação. Todos esses fins estão sobrepostos ao uso preferencial para abastecimento humano e animal conforme a legislação. Os descaminhos e equívocos desse projeto, aliados ao seu alto custo, inclusive com denúncias de superfaturamento, autorizam a vê-lo como mais um empreendimento do governo para atender aos interesses principalmente do agronegócio e da bancada ruralista, entre outros.

\section{O caso do uso de inseticidas para controle de endemias e pragas urbanas}

A problemática dos agrotóxicos e suas implicações para a saúde humana e para o ambiente não se restringem à produção agrícola ou da pecuária.

O controle de vetores urbanos é uma grande fonte de contaminação por substâncias químicas com os mesmos princípios ativos de agrotóxicos. Nesse caso, a nomenclatura utilizada para esse produto é saneante desinfestante, referindo-se àquele destinado à desinfestação de ambientes urbanos, sejam eles residenciais, coletivos, públicos ou privados, que matam, inativam ou repelem organismos indesejáveis no ambiente, sobre objetos, superfícies inanimadas, ou em plantas. Esse conceito abrange os termos "inseticidas", "reguladores de crescimento", "rodenticidas", "moluscicidas" e "repelentes" (BRASIL. ANVISA, 2010).

Um grupo de empresas desinsetizadoras utiliza esses domissanitários dando às pessoas a falsa ideia de uso seguro e eficaz para solucionar os problemas das pragas urbanas decorrentes, de modo geral, da falta ou insuficiência de saneamento ambiental. Um verdadeiro ocultamento de risco, sob a denominação desses venenos como "remédios para baratas", "remédios para mosquitos", "remédios para ratos" etc. Além disso, diversos produtos estão à venda livremente nos supermercados para uso doméstico. Muitos são maquiados em engenhocas elétricas, sem odor, e propagandeados como produtos "ecológicos" ou "que fazem bem à saúde".

Segundo dados da Associação Brasileira de Controle de Vetores e Pragas (ABCVP), o setor de desinsetização no Brasil movimenta, em média, mais de um bilhão de reais por ano, e tem previsão de crescimento anual de $10 \%$ nos próximos anos. Outro dado a ser destacado é atuam em todo o país 3.589 empresas, cerca de $50 \%$ das quais na informalidade (ABCVP, 2012). O fato de movimentar um capital tão elevado acaba sendo um estímulo à abertura de novas empresas, formalizadas ou não, o que dificulta ainda mais as já precárias ações de fiscalização. 
A informalidade pode ser um agravante, pois constitui um condicionante de vulnerabilidade ambiental e ocupacional nas áreas urbanas. As empresas especializadas em controle de vetores e pragas urbanas prestam serviço em diversos ambientes, como áreas hospitalares, clínicas, clubes, centros comerciais, escolas, universidades, residências, locais de entretenimento, condomínios residenciais e comerciais, veículos de transporte coletivo, dentre outros (BRASIL. ANVISA, 2010). Essas empresas são responsáveis por manipular, transportar, inutilizar e descartar embalagens, após o licenciamento ambiental e sanitário concedidos pelas autoridades competentes (BRASIL. MDA, 2009). Empresas que atuam na informalidade muito provavelmente não garantem a segurança da população humana e do ambiente que as cerca no processo de aplicação desses venenos.

\section{Quadro 2.7 - Cronologia do aparecimento e desenvolvimento dos inseticidas}

\begin{tabular}{|c|c|}
\hline \multicolumn{2}{|l|}{ Inseticidas de primeira geração } \\
\hline Inorgânicos & Enxofre, arsênico, fluoreto e ácido bórico \\
\hline Orgânicos vegetais & Nicotina, piretrinas naturais, rotenona \\
\hline Orgânicos minerais & Óleos minerais \\
\hline \multicolumn{2}{|c|}{ Inseticidas de segunda geração - orgânicos sintéticos } \\
\hline Clorados & DDT, aldrino, dodecacloro, BHC \\
\hline Fosforados: (não sintéticos) & Diazinon, dichorvos,DDPV \\
\hline Carbamatos: (não sistêmicos) & Propoxur, bendiocarb etc. \\
\hline Piretróides & Deltametrina, permetrina. cypermetrina,cyfluthrin etc. \\
\hline \multicolumn{2}{|l|}{ Inseticidas de terceira geração } \\
\hline Biológicos & Fungos, bactérias e vírus \\
\hline Fermônios & Goosyplure, grandlure e muscanone \\
\hline \multicolumn{2}{|l|}{ Inseticidas de quarta geração } \\
\hline $\begin{array}{l}\text { Hormônios e inibidores de } \\
\text { crescimento }\end{array}$ & $\begin{array}{l}\text { Diflubenzuron, methoprene, ciromazina, hydroprene e } \\
\text { juvabiona }\end{array}$ \\
\hline \multicolumn{2}{|l|}{ Inseticidas de quinta geração } \\
\hline Anti-hormônios & $\begin{array}{l}\text { Vegetal - precocenos e microrganismos lactonas (aver- } \\
\text { mectin) }\end{array}$ \\
\hline
\end{tabular}

Fonte: www.encoppragas.com.br/inseticidas_92.html. Acesso em 8 jun. 2012. 
Os inseticidas podem ser caracterizados cronologicamente, segundo o seu aparecimento e desenvolvimento (quadro 2.7). Quase todos os inseticidas de primeira geração já não mais usados; dentre as exceções, estão o enxofre, o ácido bórico e o arsênico, cujo uso como formicida foi relatado por $20 \%$ das propriedades com produção de frutas na Serra Gaúcha (FARIA; ROSA; FACCHINI, 2009). Os de segunda geração são ainda os mais usados. Os clorados foram proibidos, devido ao seu elevado efeito residual no ambiente. Os demais são largamente empregados. Dentre os inseticidas de terceira geração, existem algumas formulações microbianas. Os feromônios são os mais específicos, apesar de não serem classificados como inseticidas. Os inseticidas de quarta geração, como os juvenoides, atuam no processo de formação da cutícula do inseto (quitina), inibindo o seu crescimento. Por fim, os inseticidas de quinta geração estão, na sua maior parte, em processo de desenvolvimento.

Um caso ilustrativo da carga química a que está submetida principalmente a população urbana é o do controle vetorial da dengue, em que estão envolvidos mais quarenta mil agendes de saúde (antigos guardas sanitários). Este tema foi tratado no livro Abordagem Ecossistêmica em Saúde: ensaios para o controle da dengue, organizado por Augusto, Carneiro e Martins (2004). Depois de estudar a operação de controle vetorial do programa nacional do MS, os autores concluíram que a política vigente é "perdulária, perigosa e inócua", por centrar no vetor as ações de controle dessa doença mediante venenos nocivos para a saúde humana, e sem obter os resultados esperados. Pelo contrário, o mosquito tornou-se resistente ao inseticida de eleição, o país passou da condição epidêmica para endêmica/epidêmica; os casos passaram a ter maior letalidade e as crianças ficaram mais suscetíveis (AUGUSTO et al., 1998).

Fracasso geral do modelo, segundo Augusto e colaboradores (1998), mas mesmo assim ele permanece. Diante da resistência do Aedes aegypti, vetor da dengue, o MS introduziu outro larvicida: o diflubenzuron. A Secretaria Municipal de Recife teve oportunidade de verificar o rápido aparecimento de metahemoglobinemia em trabalhadores da saúde expostos a esse produto larvicida. Felizmente, a decisão do secretário municipal de Saúde dessa cidade foi comprar, à custa do erário local o biocida orgânico, mesmo sob pressão do MS para manter o uso do veneno nocivo. Como vemos, o mesmo modelo químico-dependente observado na lavoura aqui é aplicado à saúde pública. O que é grave, pois se espera das ações sanitárias proteção da saúde, e não submissão a situações de potenciais danos à saúde.

Outro grande problema tornado invisível é a realização de capina química com agrotóxicos nas áreas urbanas, que embora proibido pela Anvisa (2010), continua sendo realizada pela maioria dos municípios brasileiros. 


\section{Uso doméstico de agrotóxicos}

O uso de piretroides e piretrinas, mesmos grupos químicos de alguns agrotóxicos, é disseminado também nos ambientes domésticos como desinfestantes, pois estão na composição de inseticidas de venda livre. Esses produtos estão entre as principais causas de intoxicação no ambiente doméstico e de manifestações alérgicas principalmente em crianças (PRESGRAVE; CAMACHO; VILLAS BOAS, 2008; WERNECK; HASSELMANN, 2009).

Ainda nos ambientes domésticos é muito comum o uso de produtos na jardinagem amadora. Os produtos destinados a esse fim, que podem incluir organofosforados, carbamatos, piretrinas e piretroides, dentre outros, são aqueles destinados à venda direta ao consumidor, com a finalidade de aplicação em jardins residenciais e plantas ornamentais cultivadas sem fins lucrativos, para o controle de pragas e doenças, bem como aqueles destinados à revitalização e ao embelezamento das plantas (BRASIL. MS, 1997). Da mesma maneira que os desinfestantes, esses produtos também constituem fatores de exposição aos mesmos princípios ativos dos agrotóxicos e podem ser mais uma fonte de intoxicação de crianças.

De modo geral, o controle de vetores utilizando venenos tira o foco de outras ações que são importantes para ações de prevenção dessas e outras doenças. Políticas de saneamento básico, redes de coleta e tratamento de esgoto sanitário e coleta seletiva e tratamento final de resíduos são estratégicos para o controle de vetores e reservatórios animais.

Esse modelo químico contribui para a insustentabilidade também do espaço urbano. Do mesmo modo que na agricultura, o uso de desinfestantes no ambiente urbano acaba por desencadear resistência nos vetores, impondo um ciclo cada vez mais dependente de venenos, expondo cada vez mais a população humana aos efeitos tóxicos decorrentes dessas substâncias e degradando a biodiversidade, já tão escassa nas áreas urbanas por conta do desmatamento e da ocupação desordenada.

Além disso, tem sido verificado que o uso de inseticidas em área urbana reforça a distribuição socialmente desigual dos riscos. Um estudo avaliou cerca de dois mil domicílios em área urbana de Pelotas (RS) e confirmou que em $89 \%$ deles houve uso de inseticidas nos 12 meses anteriores (DIEL; FACCHINI; DALLAGNOL, 2003). No momento da entrevista, em $79 \%$ dos domicílios verificou-se que inseticidas foram usados. Os piretroides e organofosforados foram os grupos químicos encontrados com maior frequência. Além de as telas nas janelas serem mais comuns em domicílios de melhor condição econômica, observou-se nítida influência da renda em relação ao tipo químico, sendo os piretroides mais utilizados nos domicílios de melhor renda (em pastilhas e aerossóis) e os organofosforados predominantes em domicílios mais pobres (menor custo?). Vê-se, assim, que as desigualdades sociais se manifestam até na escolha de tipos químicos de inseticidas com predomínio dos tipos de maior toxicidade (organofosforados) entre as pessoas mais vulneráveis. 


\section{A invisibilidade dos agrotóxicos usados pela área veterinária}

Uma questão que tem chamado a atenção dos profissionais e pesquisadores da área, bem como de representantes de organizações sociais e ambientais, é o fato de os produtos veterinários estarem submetidos a uma legislação diferente daquela dos demais agrotóxicos, embora tenham funções equivalentes (inseticidas, por exemplo) e muitas vezes apresentem o mesmo ingrediente ativo de outros agrotóxicos de uso agrícola.

Uma publicação recente (SILVA; MOREIRA; PERES, 2012) informa que existem, atualmente, 7.222 produtos de uso veterinário autorizados para comercialização no país, com destaque para os antibióticos e os produtos de combate aos ectoparasitas (em particular os carrapaticidas). Esses produtos são regulados exclusivamente pelo MAPA.

Com relação aos carrapaticidas e a outros produtos de controle de ectoparasitas, uma importante questão se coloca como tema de grande relevância para a Saúde Coletiva no país: esses produtos são formulados à base de princípios ativos considerados agrotóxicos, agentes químicos reconhecidamente prejudiciais para a saúde humana e para o ambiente.

No Brasil, a Lei 7.802, de 11 de julho de 1989, prevê que o registro de agrotóxicos deve se dar mediante aprovação por comitê que inclui os Ministérios da Agricultura, Pecuária e Abastecimento (que avalia a eficiência agronômica dos produtos), da Saúde (que avalia o potencial tóxico dos produtos à saúde humana) e do Meio Ambiente (que avalia o potencial tóxico dos produtos para o ambiente e a biota). Isso leva a uma análise mais abrangente dos riscos relacionados ao uso desses agentes químicos nas diversas atividades a que se destinam.

Os agrotóxicos de uso veterinário, por sua vez, são analisados exclusivamente pelo MAPA, conforme estabelecido pelo Decreto 5.053, de 22 de abril de 2004, e atualizado no Decreto 6.296, de 11 de dezembro de 2007. Assim, produtos formulados com o mesmo princípio ativo, numa mesma concentração, podem ter avaliações distintas, para fins de registro, dependendo de sua utilização na agricultura ou na pecuária, o que coloca algumas questões para análise: a) estarão os trabalhadores da pecuária mais vulneráveis aos efeitos nocivos desses pesticidas que os trabalhadores da agricultura?; b) haverá influência desse processo de registro e controle diferenciado sobre a percepção de riscos dos trabalhadores da pecuária?; c) haveria diferença sobre as práticas de utilização de pesticidas de uso veterinário, levando a maior exposição ocupacional e ambiental a esses agentes tóxicos?

Os autores conduziram um estudo para avaliar a percepção de riscos de trabalhadores sobre agrotóxicos de uso veterinário. No que diz respeito aos trabalhadores da pecuária leiteira, a invisibilidade de riscos associados ao manejo de agrotóxicos de uso veterinário aumenta sua exposição a esses agentes químicos, que pode acarretar graves 
problemas de saúde, muito dos quais com sintomas tardios e consequências sérias. Essa mesma invisibilidade de riscos acaba por levar ao negligenciamento (nem sempre intencional) do respeito ao período de carência entre a aplicação de agrotóxicos de uso veterinário no gado e a retirada do leite para consumo humano. E, assim, acaba por colocar em situação de risco outro - e muito mais numeroso - grupo populacional, representado pela população consumidora de leite (SOARES et al., 2012). 
PARTE 2

SAÚDE, AMBIENTE

E SUSTENTABILIDADE

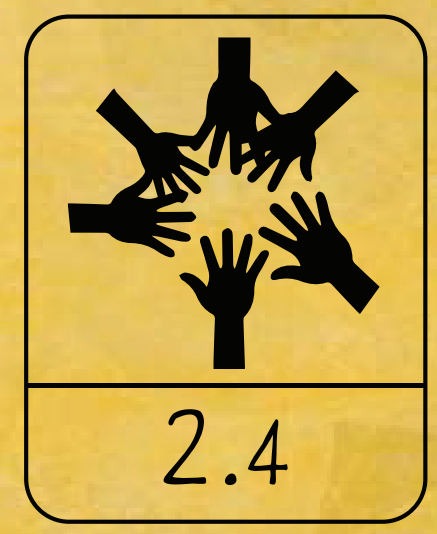

LUTAS, RESISTEENCIAS, (RE)CONSTRUÇÃO DOS TERRITÓRIOS E SUSTENTABILIDADE

\section{dossiêABRASCO}

As populações que habitam o espaço rural brasileiro compõem uma rica diversidade étnica e cultural. Povos indígenas, quilombolas e comunidades tradicionais - gerazeiros, vazanteiros, ribeirinhos, pescadores - vivem em interação com seus ecossistemas, desenvolvendo formas de agricultura, e são desafiados a defender suas terras e seus direitos territoriais, ou a conquistá-los.

O Brasil é um dos países mais desiguais do mundo, e a histórica concentração fundiária contribui estruturalmente para que essa realidade não se altere. Em 2009, os proprietários com menos de 10 hectares (ha) de terra somavam 1.744 .540 , o que representava $33,7 \%$ do total das propriedades e $1,4 \%$ do total das terras. No outro extremo da estrutura fundiária do Brasil, os grandes proprietários de terras (que possuem mais de 1.000 ha) eram 79.296, o que representava $1,6 \%$ dos imóveis rurais, possuindo $52,2 \%$ de todas as terras agricultáveis no Brasil (tabela 2.2).

Segundo Fernandes (2005), a questão agrária no Brasil tem como elementos principais a desigualdade, a contradição e o conflito. Para se desenvolver, o capitalismo precisa expropriar o trabalhador dos meios de produção e de seu conhecimento; produz e intensifica, portanto, a alienação do homem, mas na atualidade em escala muito mais dramática. Esse processo, segundo o autor, é inerente ao capitalismo e, portanto, insuperável: "ou convive-se com ele, administrando-o politicamente, procurando minimizar os seus efeitos devastadores, produtores de pobreza e miséria, ou supera-se o capitalismo" (FERNANDES, 2005, p. 3-4). Nesse processo de desterritorialização dos trabalhadores rurais emerge a resistência e organização, e o campesinato se (re)territorializa em luta. 
Tabela 2.2 - Estrutura fundiária no Brasil em 2009*

\begin{tabular}{lrr|rr|r}
\hline \multirow{2}{*}{$\begin{array}{l}\text { Estratos de } \\
\text { área total (ha) }\end{array}$} & \multicolumn{2}{c|}{ Imóveis } & \multicolumn{2}{|c|}{ Área total } & \multirow{2}{*}{$\begin{array}{c}\text { Área média } \\
\text { (ha) }\end{array}$} \\
\cline { 2 - 5 } & $\mathrm{n}^{\circ}$ de imóveis & \multicolumn{1}{|c|}{ Em ha } & \multicolumn{1}{c}{$\%$} & \\
\hline Até 10 & 1.744 .540 & 33,7 & 8.215 .337 & 1,4 & 4,7 \\
\hline De 10 a 25 & 1.316 .237 & 25,4 & 21.345 .232 & 3,7 & 16,2 \\
\hline De 25 a 50 & 814.138 & 15,7 & 28.563 .707 & 5 & 35,1 \\
\hline De 50 a 100 & 578.783 & 11,2 & 40.096 .597 & 7 & 69,3 \\
\hline De 100 a 500 & 563.346 & 10,9 & 116.156 .530 & 20,3 & 206,2 \\
\hline De 500 a 1.000 & 85.305 & 1,6 & 59.299 .370 & 10,4 & 695,1 \\
\hline De 1.000 a 2.000 & 40.046 & 0,8 & 55.269 .002 & 9,7 & $1.380,1$ \\
\hline Mais de 2.000 & 39.250 & 0,8 & 242.795 .145 & 42,5 & $6.185,9$ \\
\hline Total & 5.181 .645 & 100 & 571.740 .919 & 100 & 110,3 \\
\hline
\end{tabular}

* Situação em março de 2009; o Incra excluiu 273.849 imóveis rurais com dados inconsistentes. Fonte: Incra. Sistema Nacional de Cadastro Rural (BRASIL. MDA, 2011).

No que diz respeito aos trabalhadores(as) rurais organizados em sindicatos e movimentos sociais, os dois Planos Nacionais de Reforma Agrária (1985 e 2003) até hoje formulados não foram implementados, e a reforma agrária continua alimentando o sonho das populações que se recusam a migrar para a cidade, na esperança de mudança de modelo de desenvolvimento.

A ocupação de terras é uma das principais estratégias dos movimentos socioterritoriais do campo no Brasil e um dos momentos de luta pela terra; com a ocupação e conquista de assentamentos rurais, inicia-se uma nova etapa: ainda é necessário conquistar condições de vida e de produção na terra, outro tipo de desenvolvimento que possibilite o estabelecimento da agricultura camponesa. Dados sobre as lutas no campo e a realização da reforma agrária têm demonstrado que, no Brasil, esta só avança com pressão dos movimentos sociais (GIRARDI, 2008).

Com o objetivo de sistematizar os dados de ocupações de terra e assentamentos rurais, foi criado em 1999 o projeto Dataluta (Banco de Dados da Luta pela Terra). No período compreendido entre 2000 e 2007 o Dataluta registrou 89 movimentos atuantes no campo (que organizaram e realizaram pelo menos uma ocupação), dos quais seis estiveram presentes com maior intensidade na luta pela terra: o MST (Movimento dos Trabalhadores Rurais Sem Terra), a Contag (Confederação Nacional dos Trabalhadores na Agricultura), o MLST (Movimento de Libertação dos Sem Terra), a CPT (Comissão Pastoral da Terra), a Fetraf (Federação da Agricultura Familiar) e a OLC (Organização da Luta no Campo). Territorializado em quase todo o país (com exceção dos estados do Amazonas, Acre e Amapá), o MST foi o movimento que mais ocupações de terra realizou nesse período: 2.188, das quais participaram 376.229 famílias (SOUZA; FERNANDES, 2009). 
Os dados sobre conflitos entre latifundiários e movimentos sociais no campo e o grau de exploração violenta a que os trabalhadores rurais estão expostos nas fazendas pelo interior do Brasil oferecem um retrato do que significa o desenvolvimento da agricultura capitalista nas últimas décadas em mais uma faceta conservadora da modernização. Entre 1985 e 2007 a CPT registrou 1.117 ocorrências de conflitos no campo com morte, em que 1.493 trabalhadores rurais foram assassinados. Em 2008 e 2009 foram registrados 53 assassinatos. Do total de conflitos, apenas 85 haviam sido julgados até 2010; nesses julgamentos, 71 executores dos crimes foram condenados, 49 absolvidos e foram condenados apenas 19 mandantes, dos quais nenhum se encontrava preso naquele ano. Mais que uma face conservadora da questão agrária no Brasil, esses dados denunciam de forma clara o poder e o domínio dos grandes proprietários de terras sobre o Judiciário. Além disso, em 2007, 2008 e 2009, foram apuradas, respectivamente, 152,216 e 169 denúncias de trabalho escravo e 5.973, 5.266 e 4.283 trabalhadores foram libertados. Foram fiscalizados, nesses anos, respectivamente, 57,36\%, 77,14\% e $70,42 \%$ dos casos registrados. Os casos não apurados pelo Ministério do Trabalho se concentram nas regiões Norte e Nordeste e o trabalho escravo se concentra nas regiões Norte, Nordeste e Sudeste, mas ocorre em todo o país (CPT, 2010).

A palavra "agronegócio" tem origem na década de 1990 e representa uma construção ideológica na tentativa de consolidar uma imagem de novo modelo de desenvolvimento da agricultura: sofisticado, eficiente, produtivo, em contraposição à imagem da agricultura capitalista vinculada ao latifúndio, que carrega o estigma da exploração, do trabalho escravo, da extrema concentração da terra, do coronelismo, do clientelismo, da improdutividade e do desmatamento. Na verdade, representam o mesmo modelo que domina historicamente a produção agrícola no país - grandes propriedades de terras que produzem para exportação -, mas que sofre modificações e adaptações em suas diferentes fases, intensificando a exploração da terra e do homem (FERNANDES, 2004).

Outro projeto importante de visibilização dos conflitos no campo brasileiro é o de realização do Mapa de Injustiça Ambiental e Saúde no Brasii ${ }^{10}$, organizado pela Fiocruz e pela Federação de Órgãos para Assistência Social e Educacional (Fase), com apoio do MS. O mapa apresenta cerca de trezentos conflitos socioambientais em todo o país e foi criado com o objetivo de "apoiar as lutas de inúmeras populações e grupos atingidos/ as em seus territórios por projetos e políticas baseados numa visão de desenvolvimento considerada insustentável e prejudicial à saúde".

A pesquisa a partir da palavra-chave "agrotóxico" no Mapa de Injustiça Ambiental e Saúde no Brasil leva a 55 registros de conflitos em todo o país (figura 2.11). Sem dúvida, tais registros não representam todos os conflitos que a utilização desses biocidas no Brasil provoca, mas expressam a complexidade e gravidade da realidade brasileira e os mais diferentes impactos e grupos impactados por esses produtos.

${ }^{10}$ www.conflitoambiental.icict.fiocruz.br, pesquisa realizada em 30 de maio de 2012. 


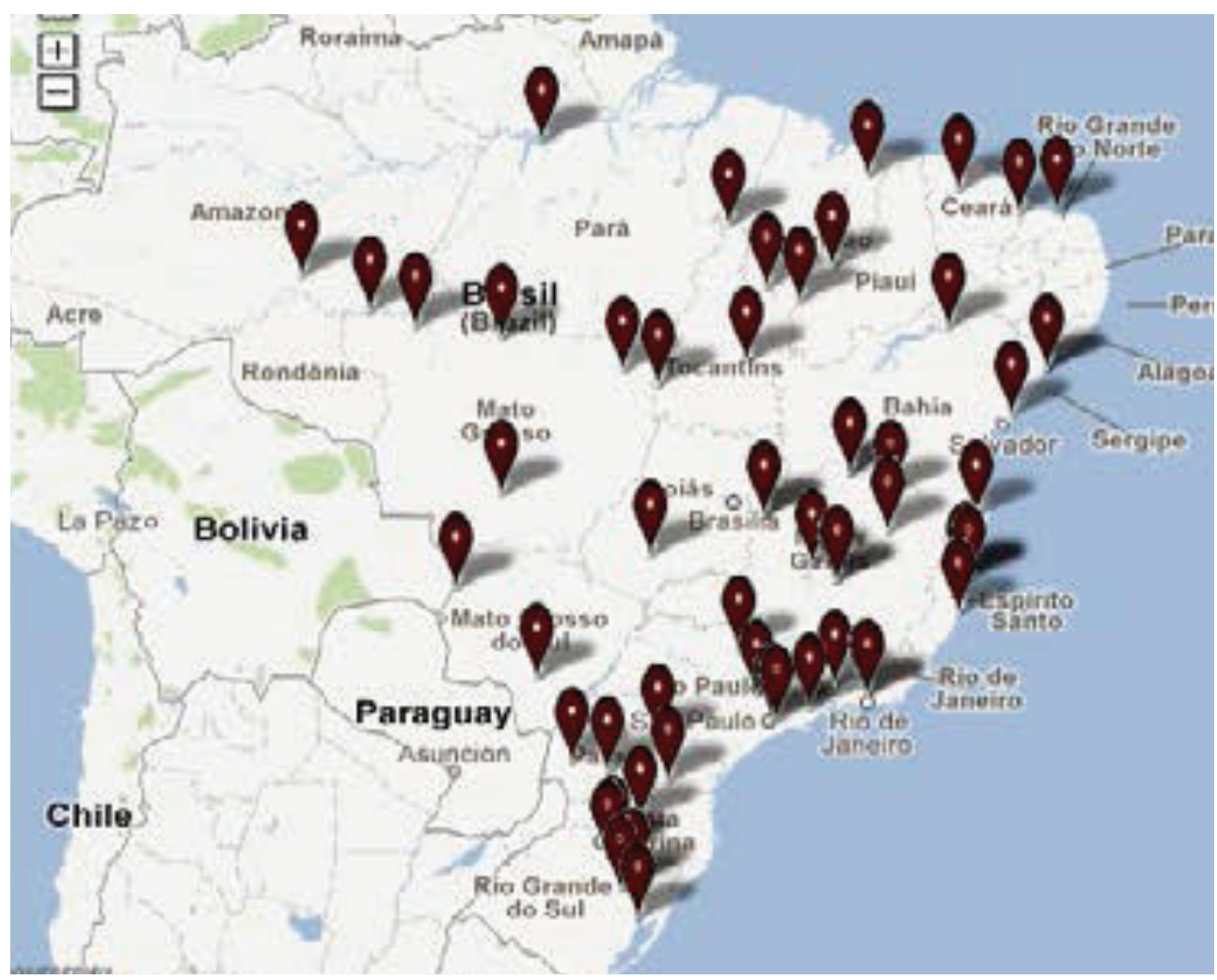

Fonte: Mapa de Injustiça Ambiental e Saúde no Brasil, 2012.

Desde que a Rede Brasileira de Justiça Ambiental (RBJA) foi criada, o tema do agronegócio, da expansão das monoculturas e da contaminação por agrotóxicos sempre esteve fortemente presente nos debates por ela promovidos ou dos quais tem participado. Os conflitos registrados no mapa associados às monoculturas estão presentes em todas as regiões, embora a aparentemente maior dispersão na região Amazônica não expresse adequadamente a vastidão dos territórios em conflito no norte do país, marcado pela forte expansão da fronteira agrícola.

A expansão dos monocultivos pelo país, segundo os resultados do mapa, entra em conflito com povos indígenas, comunidades quilombolas, ribeirinhas, colônias de pescadores, agricultores rurais e campesinos, boias-frias que trabalham nos canaviais, populações que vivem próximas às áreas de pulverização aérea, além dos grupos ambientalistas que procuram defender os ecossistemas ameaçados. O agronegócio, e seu processo produtivo, são responsáveis por inúmeros efeitos: a grilagem de terras em que há disputa por territórios rurais habitados por povos tradicionais e assentados da reforma agrária; a degradação dos ecossistemas, que afeta principalmente as populações 
que dependem de sua vitalidade, como indígenas, quilombolas, comunidades tradicionais ${ }^{11} \mathrm{e}$ agricultores dedicados à agroecologia; a contaminação por agrotóxicos das populações expostas, sobretudo os trabalhadores e moradores de áreas pulverizadas, ou ainda as populações atingidas por acidentes ambientais que atingem corpos hídricos e inúmeros municípios, e mesmo os consumidores de alimentos contaminados. Revela-se, assim, como a expressão mais perversa da violência contra lideranças e populações que habitam tais territórios e buscam defender seus direitos e modos de vida.

Por exemplo, no Vale do Jaguaribe, Ceará, ocorre um caso emblemático de injustiça ambiental vinculado à fruticultura de exportação. A política de irrigação em desenvolvimento desde a década de 1980 permitiu a instalação de empresas voltadas para a exportação de melão e abacaxi, com uso intensivo de agrotóxicos e inúmeros casos de contaminação ambiental, de trabalhadores e da população exposta na região, inclusive por pulverizações aéreas. Trabalhos realizados pela Universidade Federal do Ceará, coordenados pelo Núcleo Tramas, registram a ocorrência de mortes diretamente associadas aos agrotóxicos. Os conflitos na região e a luta contra o agronegócio também produzem violências, que culminaram com o assassinato, em 21 de abril de 2010, do agricultor, ambientalista e líder comunitário José Maria Filho, em Limoeiro do Norte. Sua morte é atribuída, inclusive, às denúncias que ele fazia de que as pulverizações aéreas envenenavam comunidades, terras, águas e animais. Contudo, sua morte não foi em vão: o Movimento 21 foi criado para dar continuidade às lutas que motivaram - e ceifaram - sua vida.

No universo dos trabalhadores rurais, as comunidades camponesas, mais especificamente, têm construído alternativas ao modelo do agronegócio. Diversas são as experiências agroecológicas em curso, a despeito da invisibilização, do desamparo e despreparo das políticas públicas e do encurralamento pelo agronegócio.

Há mais de trinta anos, comunidades do Tabuleiro de Russas, no Ceará, são protagonistas da construção de formas de organização comunitária para a convivência com o Semiárido, em transição agroecológica. Desenvolvendo atividades produtivas como agricultura, apicultura, pesca de subsistência, ovinocultura, extração de palha e óleo de carnaúba e coleta de castanha, essas comunidades têm viabilizado alternativas para a gestão das águas e se dedicado às questões da juventude e da cultura. $\mathrm{O}$ vigor de suas iniciativas fez delas comunidades-modelo que, visitadas por entidades nacionais e estrangeiras, inspiram outros grupos e estabelecem relações inovadoras com as políticas públicas.

${ }^{11}$ Cabe esclarecer que nas comunidades tradicionais encontram-se os extrativistas, geraizeiros, vazanteiros, ribeirinhos, pescadores, faxinalenses, dentre outros, todos afetados pela expansão das monoculturas. A diferenciação desses grupos é, por si, complexa: do ponto de vista legal e para as políticas públicas, existem tanto legislações gerais como específicas, inclusive para povos indígenas, quilombolas e comunidades tradicionais, assim como existem órgãos responsáveis por políticas públicas também específicas. Parte da complexidade dessa diferenciação se deve ao fato de que boa parte dos quilombolas são também agricultores, gerazeiros, vazanteiros, ribeirinhos, marisqueiras, catadoras de caranguejos, dentre outros possibilidades de classificação. 
Entretanto, em 2007, tais comunidades tomaram conhecimento de que, sem qualquer consulta ou informação à população local, suas terras haviam sido decretadas de utilidade pública para fins de desapropriação pelo Departamento Nacional de Obras Contra Secas. O objetivo era implantar a segunda etapa de um perímetro irrigado, em que as melhores terras seriam disponibilizadas para as grandes empresas transnacionais da fruticultura, consolidando a inserção destas para além da Chapada do Apodi (BRAGA; SILVA; FEITOSA, 2011).

As casas e seus produtivos quintais, etnobiodiversos; a casa do mel, base da cooperativa de jovens apicultores; a casa de farinha, que presta serviço às comunidades vizinhas também; a casa de sementes, onde a biodiversidade e a autonomia dos camponeses são guardadas, nada disso é reconhecido pela política pública. Ao contrário, o Estudo de Impacto Ambiental (EIA) insiste na invisibilização da população; nele se argumenta, por exemplo, que o projeto exercerá baixo impacto sobre o meio antrópico, pois “a população local é rarefeita e vive de uma economia pouco significativa devido à escassez de recursos hídricos, não sendo tão afetada com a desapropriação" (BRAGA, 2010, p. 122).

A negação e a desqualificação do modo de vida tradicional em relação ao modelo da modernização agrícola aproximam-se do que vem sendo conceituado como racismo ambiental (BARCELLOS, 2012). Diante das evidências contrárias já fartamente divulgadas, os argumentos apresentados no EIA sobre os benefícios trazidos pelo projeto de irrigação para a população só podem ser compreendidos como retórica.

Sobre a construção de alternativas ao modelo de desenvolvimento hegemônico, em sua fragilidade e em suas potencialidades, afirmam Santos e Rodrigues (2005, p. 25):

A insistência na viabilidade das alternativas não implica, contudo, uma aceitação do que existe. A afirmação fundamental do pensamento crítico consiste na asserção de que a realidade não se reduz ao que existe. A realidade é um campo de possibilidades em que têm cabimento alternativas que foram marginalizadas ou que nem sequer foram tentadas. Neste sentido, a função das práticas e do pensamento emancipadores consiste em ampliar o espectro do possível através da experimentação e da reflexão acerca de alternativas que representem formas de sociedades mais justas. Ao apontar para além daquilo que existe, as referidas formas de pensamento e de prática põem em causa a separação entre realidade e utopia e formulam alternativas que são suficientemente reais para não serem facilmente descartadas por serem inviáveis.

Tais reflexões acolhem a perspectiva da agroecologia como um conhecimento em construção no diálogo entre a ciência moderna e os saberes tradicionais, voltando-se não apenas para a dimensão da produção, mas considerando em outra cosmovisão as inter-relações terra-território-territorialidades em suas dimensões ecológicas, culturais, políticas, e éticas. Um paradigma que valoriza o conhecimento local e empírico dos agricultores, a socialização desse conhecimento e sua aplicação ao objetivo comum da sustentabilidade (GLIESSMAN, 2000). 
Da contestação e crítica à Revolução Verde, desde fins da década de 1970 e década 1980, surge o movimento da "agricultura alternativa" no Brasil (GUHUR; TONÁ, 2012). Desde esse período, intelectuais engajados nessa luta, algumas ONGs e centros de formação em agricultura alternativa têm desenvolvido e apoiado experiências de produção saudável alternativas ao modelo de agricultura dominante em nosso país. Essas experiências compartilham valores e princípios antagônicos àqueles do agronegócio: produção diversificada, relações humanidade-natureza produtoras de saúde, autonomia dos(as) agricultores(as) para decidir sobre o modelo de produção da vida, valorização das práticas e conhecimentos tradicionais, entre outros (CARNEIRO; BÚRIGO; DIAS, 2012).

Essas experiências iniciais tiveram grande importância na formação do movimento agroecológico no Brasil, que cresceu e ganhou força nos últimos 15 anos, tendo como marco a realização, em 2002, do I Encontro Nacional de Agroecologia. Organizaram-se redes de agroecologia em diferentes biomas que se reúnem na Articulação Nacional de Agroecologia (ANA). Muitos encontros, feiras, congressos e jornadas de agroecologia foram realizadas nesse período em que os movimentos sociais e sindicais do campo incorporaram a agenda da produção agroecológica. Foram criadas escolas e cursos de agroecologia. Também merece destaque a organização da Associação Brasileira de Agroecologia (ABA) em 2004, reunindo técnicos, professores e pesquisadores que se colocam na construção de um novo modelo de desenvolvimento e de agricultura (CARNEIRO; BÚRIGO; DIAS, 2012).

O projeto Agroecologia em Rede é um sistema de informações sobre iniciativas em agroecologia composto por três bancos de dados interligados entre si - o Banco de Experiências, o Banco de Pesquisas e o Banco de Contatos (pessoais e institucionais) - e é gerenciado pela ANA, pela ABA e pela Sociedade Científica Latino-Americana de Agroecologia. Há, atualmente, disponíveis para consulta informações sobre 892 experiências agroecológicas, distribuídas por todo o território brasileiro (figura 2.12).

Assim como no Mapa de Injustiça Ambiental e Saúde no Brasil, essas experiências não representam todas as iniciativas em curso e também sofrem com a falta de visibilidade e reconhecimento, mas expressam a riqueza e diversidade das diferentes formas de resistência ao modelo do agronegócio e de construção de diferentes formas de produzir a agroecologia, como aquela desenvolvida há trinta anos em Tabuleiro de Russas, no Ceará.

Segundo o Censo Agropecuário de 2006 (IBGE, 2006), dos 5.175.489 estabelecimentos agropecuários existentes naquele período, 3.799 .279 declaram não utilizar agrotóxicos $(73,4 \%)$. Esse dado tanto revela que a utilização de venenos agrícolas se concentra em algo entre 20 e $30 \%$ dos estabelecimentos agropecuários quanto indica que há muitas experiências de produção no campo sem a utilização de biocidas - atesta, portanto, a potência e viabilidade de um modelo de desenvolvimento nos marcos da agroecologia. Cabe, contudo, ressalvar que pode ser que a parte desses estabelecimentos em que não foi relatado uso de agrotóxicos fosse improdutiva ou usada como sítios de lazer. 
Figura 2.12 - Experiências agroecológicas distribuídas por todo o território nacional

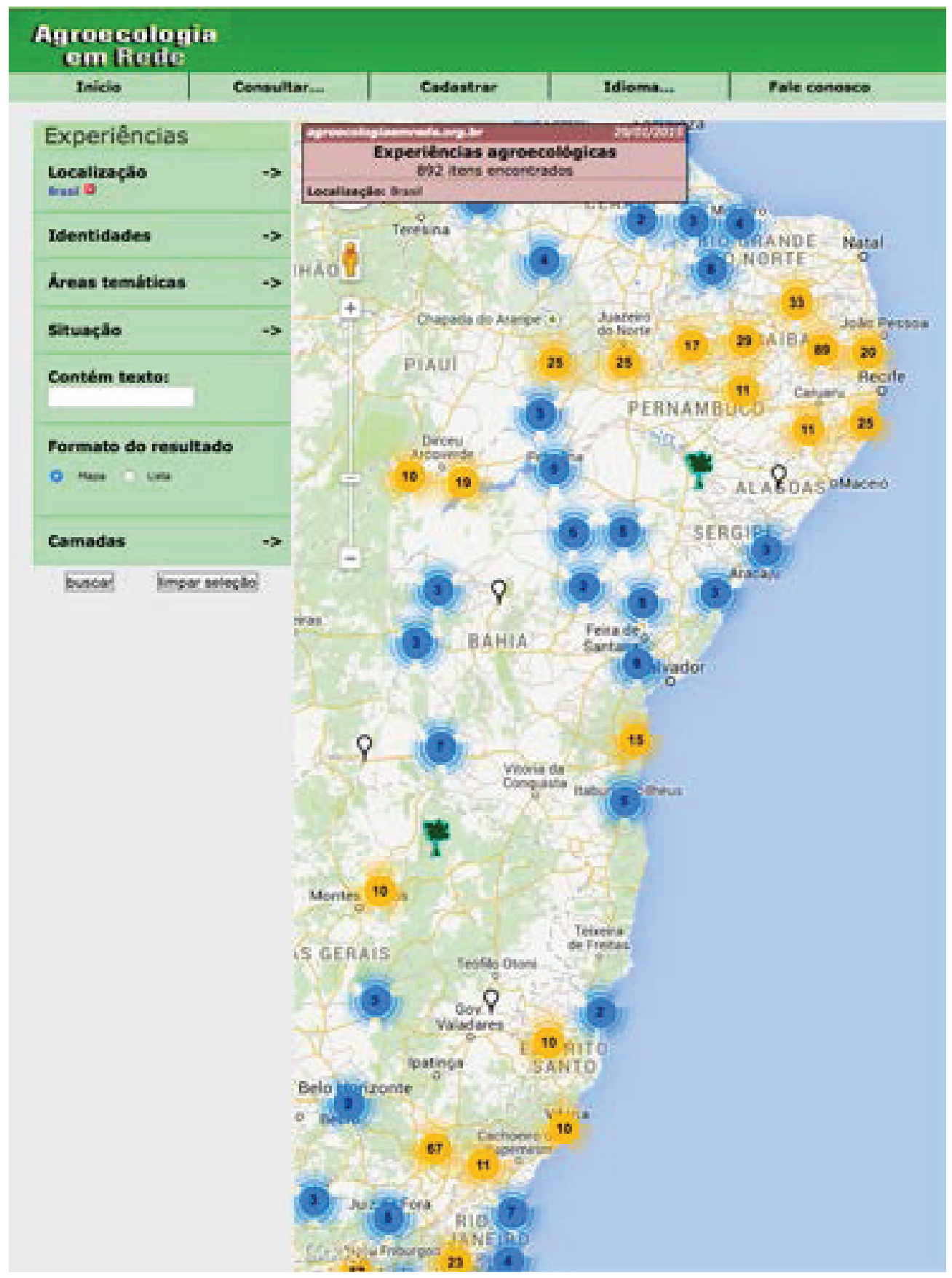

Fonte: Agroecologia em Rede. Consulta em 08 de fevereiro de 2015. 
Em 2011 foi realizado em Salvador o Encontro Nacional de Diálogos e Convergências, um espaço concebido para unir experiências em defesa de um modelo soberano e justo para a vida no planeta ${ }^{12}$. O encontro foi organizado pela ANA, pelo Fórum Brasileiro de Economia Solidária (FBES), pela RBJA, pela Rede Alerta contra o Deserto Verde (RADV), pela Abrasco, pela ABA, pelo Fórum Brasileiro de Soberania e de Segurança Alimentar e Nutricional (FBSSAN), pela Marcha Mundial de Mulheres (MMM) e pela Articulação de Mulheres Brasileiras (AMB).

Esse encontro buscou a relação entre os temas agroecologia, saúde e justiça ambiental, soberania alimentar, economia solidária e feminismo, através de diálogos e de trocas de ideias, conhecimentos e experiências. E também de convergências, porque teve como objetivo estimular que experiências e pensamentos que levem à construção de um modelo de desenvolvimento justo com o meio ambiente e com os seres humanos se encontrem e unam forças para enfrentar a forma predatória e exploratória em curso hoje, indicando, coletivamente, caminhos concretos de práticas diferenciadas.

Como expressão das convergências, no encontro foi lançado o Intermapas ${ }^{13}$, uma ferramenta dos movimentos sociais, redes e organizações para apoiar lutas nos territórios. O Intermapas reúne informações de quatro iniciativas: Agroecologia em Rede ${ }^{14}$, Farejador da Economia Solidária ${ }^{15}$, Mapa da Injustiça Ambiental e Saúde ${ }^{16}$ e Mapa dos Projetos Financiados pelo Banco Nacional de Desenvolvimento Econômico e Social (BNDES) ${ }^{17}$.

O Farejador da Economia Solidária disponibiliza os dados do Mapeamento da Economia Solidária realizado entre 2005 e 2007 pela Secretaria Nacional de Economia Solidária do Ministério do Trabalho e Emprego (Senaes/MTE) em parceria com o Fórum Brasileiro de Economia Solidária. Foram registradas 21.579 experiências em todo o Brasil, das quais 139 são empreendimentos solidários rastreáveis com a palavra-chave "agricultura" (figura 2.13). São cooperativas, associações de mulheres, grupos de pequenos agricultores, centros de agroecologia, feiras da agricultura familiar, entre outras experiências que expressam a força e viabilidade do desenvolvimento econômico dentro de outros marcos, opostos àqueles dos oligopólios concentradores de renda e produtores de desigualdades sociais e iniquidades em saúde.

12 www.dialogoseconvergencias.org

13 www.fbes.org.br/intermapas

${ }^{14} \mathrm{http}$ ///agroecologiaemrede.org.br

15 www.fbes.org.br/farejador

${ }^{16}$ www.conflitoambiental.icict.fiocruz.br

17 www.plataformabndes.org.br/mapas 


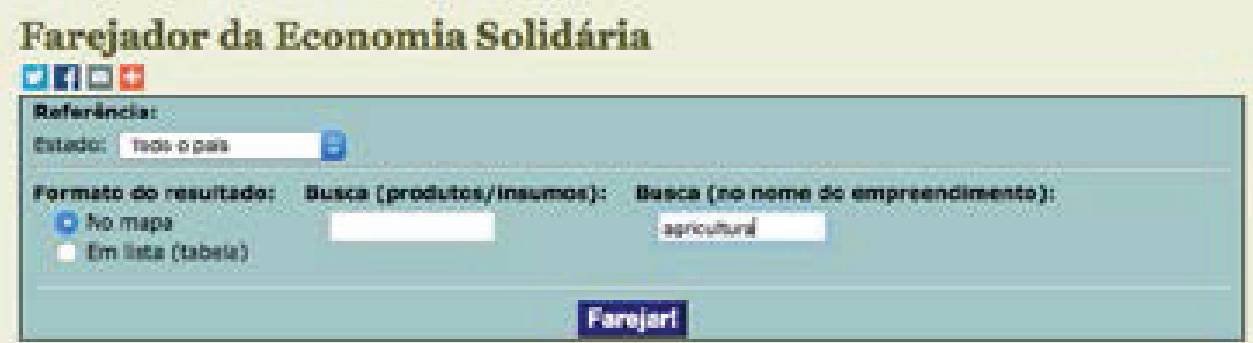

\section{9 empreendimentos solidários encontrados:}

Gerar catálogo tipe páginas amarelas desta consulta! Não conseque abrir o catálogo? Clique aqui pare aiuda...

busca (nome do empreendimento): "agricultura"

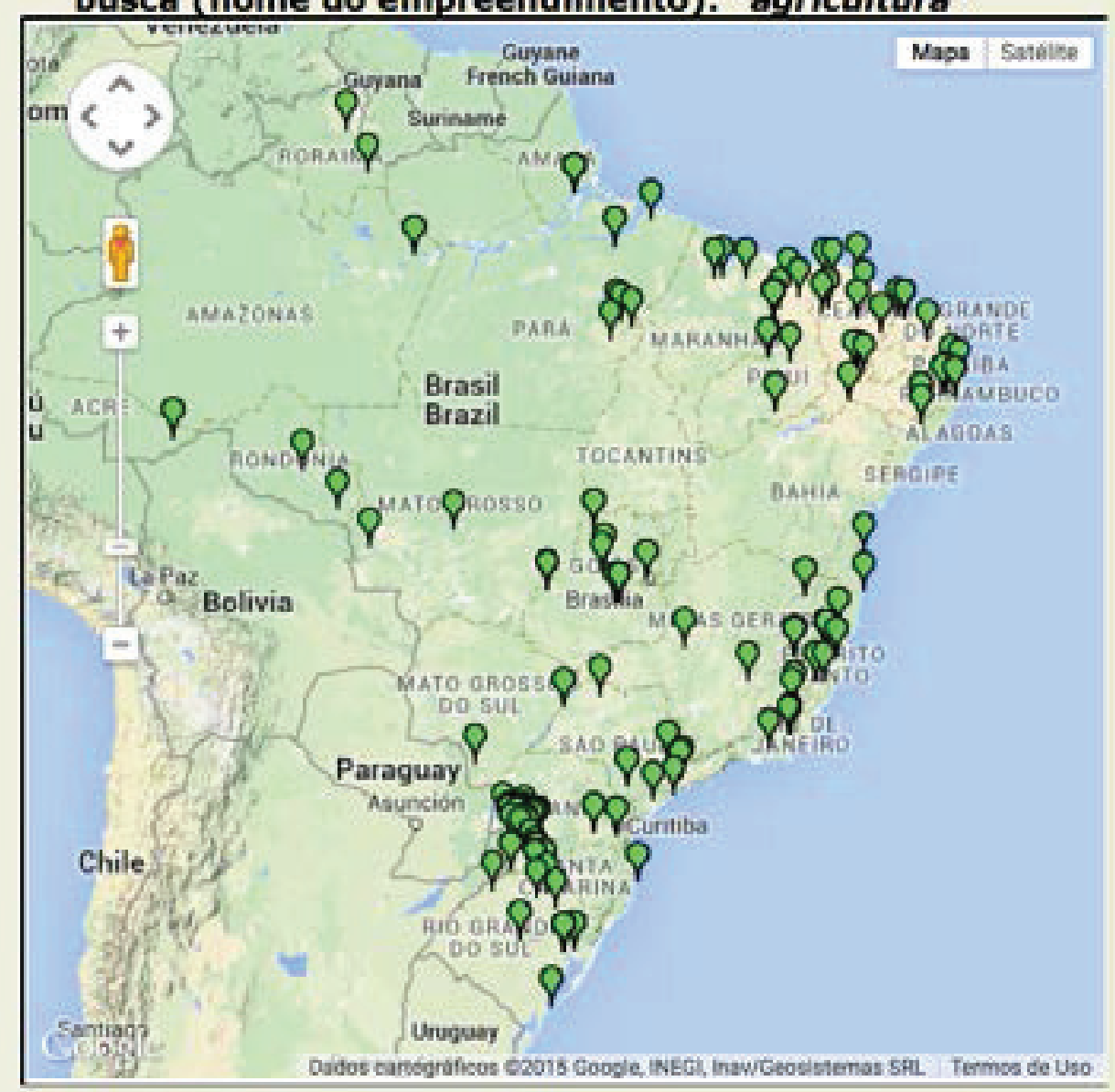

Fonte: Farejador da Economia Solidária. Consulta em 29 de janeiro de 2015. 
O Mapa dos Projetos Financiados pelo BNDES, organizado por um conjunto de organizações e movimentos sociais em torno da Plataforma BNDES, democratiza as informações sobre os investimentos desse banco que tem determinado o rumo do desenvolvimento do país. Há, atualmente, 1.359 registros disponíveis para consulta nesse mapa. Os financiamentos do BNDES tanto para a indústria química como para a indústria de agrotóxicos, entre 2001 e 2010, somaram 879 milhões e 463 mil reais (SILVA; COSTA, 2012).

No documento final do Encontro de Diálogos e Convergências, a Carta de Salvador (2011), afirma-se:

A progressiva deterioração da saúde coletiva é o indicador mais significativo das contradições de um modelo que alça o Brasil a uma das principais economias mundiais ao mesmo tempo em que depende da manutenção e seguida expansão de políticas de combate à fome e à desnutrição. Constatamos também que esse modelo estrutura e acentua as desigualdades de gênero, de geração, de raça e etnia.

Nossas análises convergiram para a constatação de que os maiores beneficiários e principais indutores desse modelo [de desenvolvimento, o agronegócio] são corporações transnacionais do grande capital agroindustrial e financeiro. Apesar de seus crescentes investimentos em marketing social e verde, essas corporações já não conseguem ocultar suas responsabilidades na produção de uma crise de sustentabilidade planetária que atinge inclusive os países mais desenvolvidos e que se manifesta em desequilíbrios sistêmicos expressos no crescimento do desemprego estrutural, na acentuação da pobreza e da fome, nas mudanças climáticas, na crise energética e na degradação acelerada dos recursos do ambiente. (...)

Os diálogos sobre os agrotóxicos e transgênicos, articulando as visões da justiça ambiental, saúde ambiental e promoção da agroecologia, responsabilizaram o Estado pelas políticas de ocultamento de seus impactos expressas nas dificuldades de acesso aos dados oficiais de consumo de agrotóxicos e de laudos técnicos sobre casos de contaminação; na liberação de Organismos Geneticamente Modificados (OGMs) sem debate democrático com a sociedade e sem atender ao princípio da precaução; na frágil vigilância e fiscalização trabalhista, ambiental e sanitária; na dificuldade do acesso aos laboratórios públicos para análise de amostras de contaminação por transgênicos e por agrotóxicos no ar, água, alimentos e sangue; terminando por promover um modelo de desenvolvimento para o campo que concentra terra, riqueza e renda, com impactos diretos nas populações mais vulneráveis em termos socioambientais.

Há um chamamento para que o Estado se comprometa com a apuração das denúncias e investigação dos crimes, a exemplo do assassinato do líder comu- 
nitário José Maria da Chapada do Apodi, no Ceará; com a defesa de pesquisadores criminalizados por visibilizar os impactos dos agrotóxicos e por produzir conhecimentos compartilhados com os movimentos sociais; com políticas públicas que potencializem a transição agroecológica - facilitando o acesso ao crédito, à assistência técnica adequada e que reconheça os conhecimentos e práticas agroecológicas das comunidades camponesas.

Não há possibilidade de convivência entre o modelo do agronegócio e o modelo da agroecologia no mesmo território, porque o desmatamento e as pulverizações de agrotóxicos geram desequilíbrios nos ecossistemas, afetando diretamente as unidades agroecológicas. As políticas públicas devem estar atentas aos impactos dos agrotóxicos sobre as mulheres (abortos, leite materno, etc.), pois estas estão expostas de diferentes formas, que vão desde o trabalho nas lavouras até o momento da lavagem da roupa dos que utilizam os agrotóxicos. $\mathrm{O}$ uso seguro dos agrotóxicos e transgênicos é um mito e um paradigma que precisa ser desconstruído.

É fundamental a convergência de nossas ações com a Campanha Nacional Permanente Contra os Agrotóxicos e Pela Vida, ampliando os diálogos e convergências com os movimentos sociais do campo e da cidade, agregando novas redes que não estiveram presentes neste Encontro de Diálogos e Convergências. Temos que denunciar esse modelo do agronegócio para o mundo e buscar superá-lo por meio de políticas públicas que possam inibir o uso de agrotóxicos e transgênicos, a exemplo da proibição da pulverização aérea, ou ainda direcionando os recursos oriundos dos impostos dos agrotóxicos, cuja produção e comercialização é vergonhosamente subsidiada pelo Estado. O fim dos subsídios contribuiria para financiar o SUS e a agroecologia.

No Intermapas é possível verificar, por exemplo, que regiões onde há investimentos do BNDES coincidem com algumas regiões de intensificação de conflitos por injustiça ambiental no Brasil. Com tamanha concentração de terras, renda e poder no Brasil, com a indução do modelo do agronegócio da agricultura pelo Estado brasileiro e a ausência de políticas públicas que promovam a agroecologia, as perspectivas em torno da economia verde, proposta pela Organização das Nações Unidas (ONU), trazem grandes preocupações, pois não há indicativos de que durante a Rio+20 se fará um balanço dos últimos vinte anos para avaliar as causas estruturais da crise ecológica, social e econômica por que passa o modelo de sociedade atual.

A Carta de Salvador guarda convergência com o relatório da $1^{a}$ Conferência Nacional de Saúde Ambiental, realizada em 2009, com o tema "A saúde ambiental na cidade, no campo e na floresta: construindo cidadania, qualidade de vida e territórios sustentáveis". Em suas diferentes etapas, a conferência mobilizou dezenas de milhares de pessoas e aprovou, com o maior número de votos, a diretriz: 
Mudança no modelo de desenvolvimento econômico de modo a promover a qualidade de vida e a preservação do ambiente, e a saúde desta e das futuras gerações com a proteção da agrobiodiversidade e da biodiversidade urbana e rural, visando à sustentabilidade socioambiental responsável (CNSA, 2010, p. 52).

\section{Campanha Permanente Contra os Agrotóxicos e Pela Vida}

A opção política do governo por legitimar a expansão do agronegócio tem gerado conflitos socioambientais e de saúde. As populações atingidas, desafiadas a lidar com problemas até então desconhecidos, têm denunciado os impactos desse modelo - expropriação das terras, proletarização em relações de trabalho precárias, degradação e contaminação ambiental, adoecimento das pessoas, desaparecimento e mudanças no modo de vida das comunidades camponesas -, trazendo a público o "outro lado" do desenvolvimento no campo e questionando, com suas lutas, os níveis toleráveis de subordinação e exploração (SANTOS, 2010).

Figura 2.14 - Cartaz de 2011 da da Campanha Permanente Contra os Agrotóxicos e Pela Vida

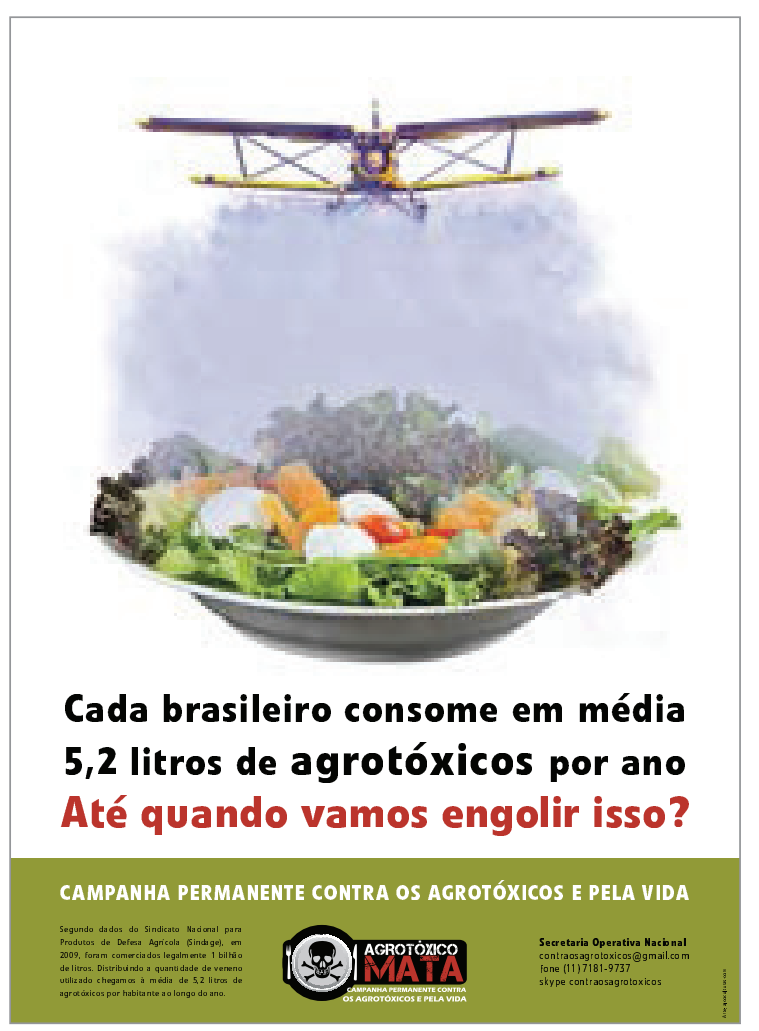

Foi assim que movimentos sociais do campo no Ceará perceberam a importância da questão do agrotóxico como tema estratégico e alertaram as organizações que compõem a Via Campesina no plano nacional. A preocupação encontrou eco e acolhida, levando à realização, em setembro de 2010, do Seminário Nacional sobre os Agrotóxicos, no qual se deliberou pela criação da Campanha Permanente Contra os Agrotóxicos e Pela Vida. No Dia Mundial da Saúde de 2011, ampla frente de movimentos sociais do campo e da cidade lançou a campanha, coordenada por mais de vinte entidades nacionais, entre as quais a Via Campesina, a Central Única dos Trabalhadores (CUT), a Articulação Nacional de Agroecologia (ANA) e o Fórum Brasileiro de Segurança e 
Soberania Alimentar e Nutricional (FBSSAN). A campanha recebeu adesões de sociedades científicas como a Abrasco e de instituições públicas como a Fiocruz e o Instituto Nacional do Câncer (Inca). Além dessas, outras entidades vêm se somando em mais de vinte comitês estaduais no Brasil e em diversos comitês locais. Inicialmente enfocando a contaminação dos alimentos por agrotóxicos, foi produzido o documentário O Veneno Está na Mesa, de Silvio Tendler, que tem possibilitado o debate sobre as relações campo-cidade, contribuído para ampliar o envolvimento dos consumidores de alimentos no questionamento do modelo de produção agrícola e pautado as políticas públicas pertinentes.

Tais políticas, ainda quando conquistadas na forma de direitos e leis, ainda demandam, para sua efetivação, o sobre-esforço da luta política (SCHERER-WARREN, 1993). Considerando o contexto em que o Estado, mais especificamente o SUS, tem exercido uma ação débil em termos da vigilância da exposição de populações a agrotóxicos (CARNEIRO; ALMEIDA, 2007), a campanha tem provocado o governo federal e o Legislativo, levando à criação de um grupo intersetorial de enfrentamento dos danos dos agrotóxicos no âmbito da Secretaria-Geral da Presidência da República, entre outras ações.

A intensa mobilização da sociedade tem levado à realização de audiências públicas e debates, à produção e difusão ampliada de informações, à proibição de pulverização aérea em alguns municípios: ações concretas que as políticas públicas de governo estavam se mostrando incapazes de realizar, o que leva a reconhecer o importante papel desempenhado por esses movimentos na proteção da saúde pública.

\section{Fórum Nacional de Combate aos Efeitos dos Agrotóxicos na Saúde e no Meio Ambiente}

Criado para funcionar como instrumento de controle social, o Fórum Nacional de Combate aos Efeitos dos Agrotóxicos na Saúde e no Meio Ambiente reúne organizações governamentais, não governamentais, sindicatos, associações profissionais, universidades e o Ministério Público do Trabalho. Teve origem nos seminários organizados por diversas representações da sociedade civil e da Anvisa e na experiência de Pernambuco, estado pioneiro na construção de um fórum de combate aos efeitos dos agrotóxicos no ano de 2001, sob a coordenação de três ministérios públicos: do Trabalho, do Estado e Federal.

O fórum promove articulação entre governos e sociedade civil para o enfrentamento dos efeitos nocivos dos agrotóxicos à saúde do trabalhador, do consumidor e do meio ambiente. Por seu intermédio, o Ministério Público do Trabalho realiza, entre outras atividades, audiências públicas e investigações, e firma Termos de Ajustes de Conduta (TAC) para a redução e restrição do uso de agrotóxico.

Atualmente, dez estados já constituíram seus fóruns e estão organizados em comissões para auxiliar as atividades dos ministérios públicos. 
PARTE 2

SAÚDE, AMBIENTE

E SUSTENTABILIDADE

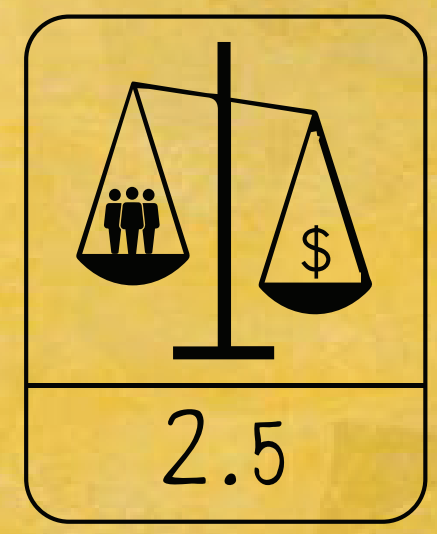

LACUNAS DE CONHECIMENTO E DE POLITICA: O QUE O ESTADO DEVERIA FAZER E NÃO FAZ

\section{dossiêABRASCO}

A capacidade das agências reguladoras para acompanhar o estado da arte no campo da toxicologia está sempre defasada, pois os marcos regulatórios não lhes proporcionam agilidade, e a discricionariedade técnica, baseada no conhecimento científico independente e aplicável em muitos dos casos enfrentados pelo toxicólogo, é vista como algo suspeito. Assim, além das questões de cunho científico, os serviços de regulação buscam o eterno equilíbrio entre, de um lado, atender à legislação e, de outro, garantir a segurança dos produtos, em um ambiente de muitas pressões: econômicas, políticas e sociais. Nesse contexto, muitas vezes os servidores também não contam com rede de proteção para exercer as suas atividades.

A Lei n. 7.802, que define as diretrizes para a avaliação de agrotóxicos, determina que sejam proibidos os produtos que apresentem a possibilidade de provocar teratogênese, carcinogênese, mutagênese e distúrbios hormonais ou danos ao aparelho reprodutor ( $\$ 6^{\circ}$ do Art. 3 da Lei 7.802/89), ou seja, trata-se de um critério de corte. O decreto que a regulamenta (n. 4.074/02), além de ratificar tal determinação, prevê que os estudos e provas devam ser executados em pelo menos duas espécies animais.

O legislador brasileiro foi muito feliz ao adotar avaliação de perigo como um critério de corte e assim antecipar, em 1989, um debate que acontece nos países desenvolvidos, os quais têm abandonado a avaliação de risco como um critério na avaliação de agrotóxicos, como ocorreu no bloco europeu em 2011.

Apesar da promulgação da Lei de Agrotóxicos, o MS não tem priorizado a implantação de serviços que respondam pelas atribuições, legal- 
mente estabelecidas, de avaliar e proceder à vigilância dos agrotóxicos. A criação da Anvisa, ao longo da última década, melhorou o aprimoramento regulatório e dos procedimentos da avaliação toxicológica para concessão de registros por outros órgãos; entretanto, ainda há muitas dificuldades para retirar do mercado produtos enquadráveis na lei que tenham o perigo conhecido.

No campo da toxicologia, a avaliação de risco é realizada como um método científico sobre os potenciais efeitos adversos decorrentes da exposição humana a agentes ou situações perigosas. Geralmente só se leva em consideração a exposição a um único composto, e de maneira descontextualizada. $\mathrm{O}$ que não corresponde à realidade em que se dão os processos de produção/trabalho e de consumo, nos quais o contato envolve mais de uma substância química, com o agravamento concomitante por outros potenciais agravos ou hábitos de vida.

Esse tipo clássico de avaliação de risco não garante a segurança da exposição a determinado produto químico. As práticas de vigilância ainda não se apoiam em conhecimento atualizado sobre a avaliação do risco acumulado que dê suporte para a tomada de decisão. Ainda não se dispõe de informações precisas quanto aos possíveis efeitos da exposição a todas as fontes de contaminação por agrotóxicos aos quais as populações humanas estão sujeitas: alimentos (como frutas, legumes, verduras, leite e carnes), a água e o ar, campanhas de saúde pública, controle de vetores e pragas, uso doméstico, jardinagem e até mesmo medicamentos de uso humano e veterinário. Por essa razão impõe-se o princípio da precaução, bem como a consideração de que as incertezas são parte desses processos, o que exige sempre muita cautela.

Nesse contexto, a exposição aos agrotóxicos que desencadeiam os mesmos efeitos tóxicos e que agem de modo semelhante potencializa ou pode atuar de forma sinérgica para o aparecimento da toxicidade, mesmo que os limites máximos de exposição, segundo as legislações pertinentes, sejam obedecidos. O conhecimento sobre os efeitos acumulados de diferentes agrotóxicos para a saúde humana e os ecossistemas ainda se encontra enormemente defasado.

$\mathrm{Na}$ avaliação das vulnerabilidades, das situações de risco e da exposição aos agrotóxicos, devem-se levar em consideração outros condicionantes no contexto das populações a eles expostas. A avaliação desse complexo contexto de determinação das intoxicações por agrotóxicos deveria considerar a exposição aos agrotóxicos e a outras substâncias químicas, agentes biológicos, físicos e psicológicos, e também aos fatores de ordem política e econômica que exercem impacto sobre os perfis de morbimortalidade.

Para fundamentar ações voltadas para a dissolução de injustiças ambientais, é preciso rever profundamente conceitos utilizados em toxicologia que, desde Paracelso, ainda seguem o padrão de linearidade entre dose e efeito. Quando estão envolvidas no processo substâncias cancerígenas e imunotóxicas, por exemplo, não é possível aceitar limites seguros de exposição; trata-se de uma "verdade científica" que hoje não se sustenta mais. 
São enormes os desafios contemporâneos no campo da ciência e da produção de conhecimento. A ciência moderna, nascida nas sociedades ocidentais e datada na emergência histórica do projeto burguês de mundo, vem cumprindo o papel de subsidiar o desenvolvimento da civilização do capital. Se muitos benefícios são fruto do sistema técnico-científico, reconhecemos que "a revolução tecnológica não é externa às relações sociais e de poder" e que "vivemos um mundo em que os maiores perigos já não mais advêm da peste ou da fome, mas, sim, das próprias intervenções feitas por meio deste mesmo sistema técnico-científico" (HAESBAERT; PORTO-GONÇALVES, 2006, p. 106; 122-3).

Diante de uma "crise histórica sem precedentes, estrutural, profunda, do próprio sistema do capital" (MÉSZÁROS, 2009, p. 42), constatamos o desenvolvimento do novo modelo de acumulação de capital, que desenvolve práticas predatórias, fraudulentas, de extração violenta da mais-valia. Agravam-se, assim, as desigualdades e as assimetrias sociais e a pilhagem dos mais vulnerados, levando à injustiça e ao racismo ambiental (ACSELRAD; HERCULANO; PÁDUA, 2004).

Vivenciamos ainda a industrialização da ciência, com a priorização de objetos de estudo que interessam ao mercado e são financiados por grandes grupos econômicos, a despeito das demandas por conhecimento sobre grupos sociais mais vulneráveis; a elaboração de pareceres com resultados previamente encomendados e acordados; a omissão da dúvida e da ignorância; e até mesmo evidências de procedimentos suspeitos na liberação dos transgênicos, entre outros (BREILH, 2008). Nesse contexto, é necessário assumir nossas responsabilidades, como campo científico, na produção da crise e da injusta sociedade de risco contemporâneas. E responder ao enorme desafio ético e histórico de contribuir para a construção de uma ciência emancipatória que, rompendo com o epistemicídio posto pela ciência moderna (SANTOS, 2010), se volte para a ecologia de saberes que tragam consigo mais sabedoria (NETO, 2011).

A nosso ver, a atividade teórica em si não é dotada da capacidade de transformar a realidade, pois depende das ações (VÁZQUEZ, 2007). A emancipação social tem de ser vivificada pelos sujeitos implicados.

Colocar-se ao lado dos mais vulneráveis (SANTOS, 2010) é uma postura ética que tem levado vários pesquisadores a ser alvo de ações judiciais de criminalização movidas pelos grandes empreendedores, especialmente no campo dos impactos ambientais e à saúde humana. Dessa forma, é urgente pautar a necessidade de garantir a autonomia da atividade acadêmica em relação as pressões ou aos interesses econômicos. 


\section{A omissão do SUS em relação às políticas de enfrentamento dos impactos dos agrotóxicos na saúde}

O SUS não tem contado com estímulos políticos, técnicos e financeiros para implantar a vigilância da saúde de populações expostas aos agrotóxicos. O MS discute há cinco anos um Plano de Vigilância e Atenção à Saúde para Populações Expostas a Agrotóxicos, mas não conseguiu, até o momento, pactuar com estados e municípios sua forma e os recursos a serem direcionados para implementá-lo. Será que essa questão não mereceria prioridade? Ou a educação relacionada aos agrotóxicos deve continuar a cargo dos representantes das empresas de agrotóxicos, cabendo apenas aceitar como verdade a ideia do "uso seguro dos agrotóxicos"? O MS não tem sido equitativo na priorização de recursos para questões como a dos agrotóxicos.

Hoje, vigora no Brasil um pacto político-econômico em que predominam os interesses da bancada ruralista, entre os quais a liberalização no trato da questão do uso de agrotóxicos no âmbito do Legislativo (mais de quarenta projetos de lei nessa direção), do Executivo (pressões sobre órgãos reguladores como a Anvisa), do Judiciário (impunidade nas mortes no campo), da pesquisa (mais de 95\% dos recursos da Embrapa estão voltados para o agronegócio) e da mídia (o agronegócio possui até canais de televisão). A novidade, em termos de uma reação organizada da sociedade civil a essa situação, foi o lançamento da Campanha Permanente Contra os Agrotóxicos e Pela Vida, no Dia Mundial da Saúde, em abril de 2011, com a formação de comitês populares em quase todos os estados brasileiros, tendo como principal bandeira de luta para 2012 o banimento dos agrotóxicos já proibidos em outros países.

A sociedade científica também tem reagido, como no lançamento do processo de elaboração da primeira parte deste dossiê sobre os Impactos dos Agrotóxicos na Saúde dos Brasileiros (www.abrasco.org.br), documento científico interdisciplinar em que uma das principais conclusões apresentadas foi a de que não são mais necessárias evidências científicas para uma ação clara de Estado visando a vigiar, proteger e promover a saúde das populações envolvidas. É hora de garantir espaço na agenda política e financeira do SUS para viabilizar a estruturação da vigilância, atenção e promoção da saúde relacionada à questão dos agrotóxicos. A articulação intersetorial e a adoção de políticas de incentivo à agroecologia articulada com a reforma agrária para que o modelo químico-dependente seja alterado são, hoje, a base da luta.

Como visto, são muitas ainda as questões relacionadas à pesquisa e à informação sobre os agrotóxicos e sua circulação no ambiente decorrentes dos processos produtivos e de consumo de agrotóxicos. As informações devem estar acessíveis a todos os interessados tanto dos níveis governamentais como da sociedade civil. Priorizar os agrotóxicos de baixa dose e organizar o sistema de informação sobre o câncer em grupos de vulnerabilizados, por exemplo, são prioridades para ontem. Algumas questões que consideramos estruturantes: 
1. Quantos e quais são os agrotóxicos que estão no mercado dos quais conhecemos a nocividade? Esta pergunta nos possibilita organizar o sistema de informação intersetorial disponibilizado para o público interessado e também estabelecer prioridades nas ações de vigilância e proteção da saúde humana e do meio ambiente.

2. O que se sabe acerca de como, no contexto real da produção e do consumo, os agrotóxicos penetram e se acumulam no meio ambiente, bem como acerca dos processos de biotransformação que, gerados nos organismos, afetam a saúde? Esta questão é fundamental para orientar as medidas de atenção à saúde e de mitigação de danos ambientais.

3. Quais são os riscos ecológicos e para a saúde humana, conhecidos e presumidos, decorrentes da utilização dos agrotóxicos? Com esta indagação podemos nos antecipar as situações morbígenas mediante ações de saúde, ambientais, educacionais etc.

4. Quem são os grupos populacionais mais vulnerabilizados? É fundamental reconhecer aqueles que podem estar expostos aos agrotóxicos e em maior perigo, especialmente os trabalhadores, as crianças e as mulheres gestantes.

5. Quais são as iniciativas das políticas atuais para, a curto prazo, reduzir ou eliminar esses riscos? É muito importante que as ações sejam desencadeadas a curto prazo, sem protelações, especialmente aquelas que visem a impedir a exposição.

A fragmentação dos dados; a diversificação de fontes difusas; a escassez de informação sobre a degradação, transformações, produtos derivados e exposição humana; a concentração da vigilância ambiental principalmente em meios fluidos ambientais (ar, água), com frequência se esquecendo do solo, dos sedimentos e dos produtos de consumo humano, tornam necessário estabelecer as vias de contaminação dos agrotóxicos e indicadores de monitoramento/vigilância para identificar:

I as lacunas nos dados de ensaio de toxicidade;

I as lacunas nos dados sobre vigilância/ exposição;

C lacunas na informação sobre as externalidades ambientais;

a magnitude dos impactos;

D prioritariamente, os impactos em grupos-sentinela e em crianças. 
A intervenção neste campo deve considerar a insuficiência do conhecimento sobre os efeitos na saúde humana e no ambiente; a necessidade de que as providências relacionadas a algumas substâncias extremamente tóxicas sejam tomadas de forma preventiva, e não tardia; as evidências de associação entre exposição e aumento de câncer, alergia e desregulação endócrina persistentes. Os objetivos principais de uma política assim estruturada seriam proporcionar um nível elevado de proteção da saúde humana e do meio ambiente para gerações atuais e futuras, e garantir justiça e soberania ambiental. O princípio que deve reger as ações é o da precaução, mediante a revalorização do natural e do mais saudável. 


\section{PARTE 2}
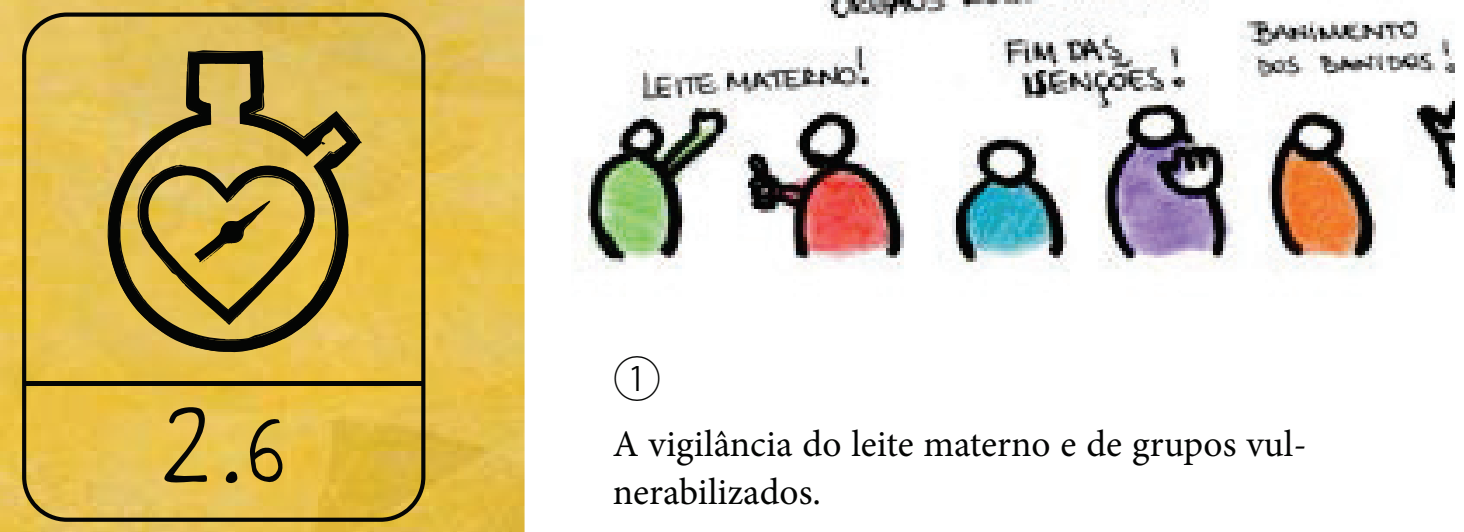

(1)

A vigilância do leite materno e de grupos vulnerabilizados.

\section{(2)}

Medidas legislativas de fortalecimento dos órgãos reguladores.

\section{DOZE PRIORIDADES EM DEFESA DA VIDA}

\section{(3)}

Fim das isenções fiscais.

(4)

Fim da pulverização aérea.

\section{(5)}

Banimento, do Brasil, dos agrotóxicos já banidos em outros países ou que apresentem evidências de efeitos proibitivos, conforme a legislação.

\section{(6)}

Capacitação dos profissionais da saúde em todos os níveis. Inclusão desta temática nas ações de capacitação, nos programas de educação continuada e de atualização para a atenção básica, as urgências, a assistência hospitalar e a assistência especializada. 


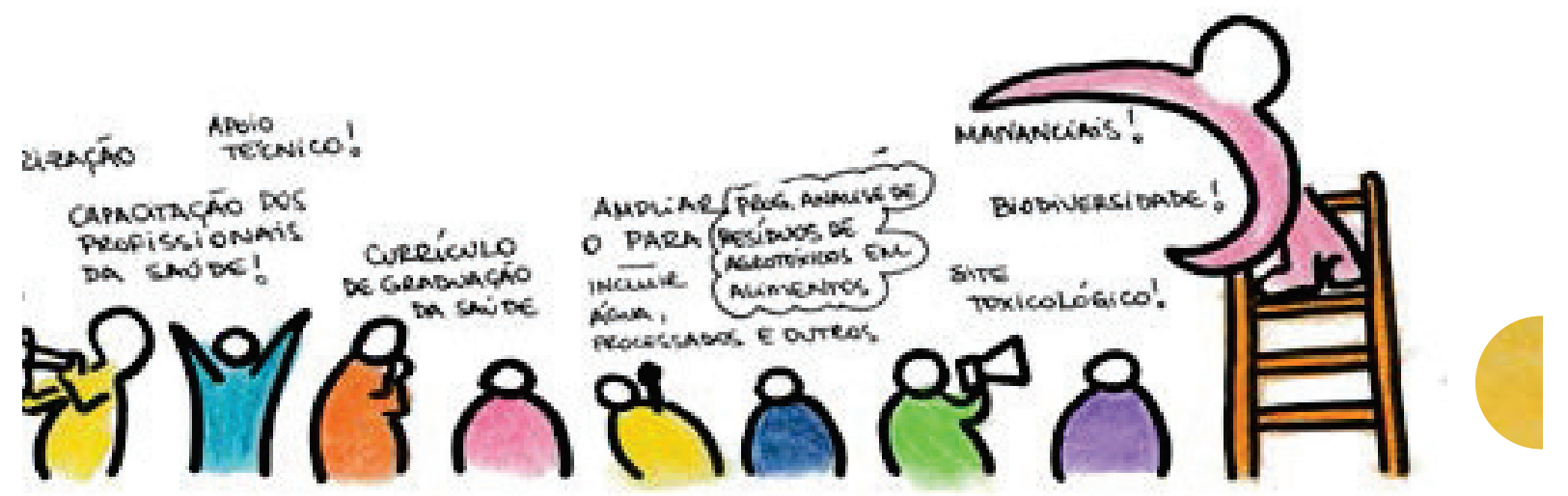

(7)

Formação de futuros profissionais da saúde: introdução, nos currículos de graduação, de conteúdos relativos aos impactos negativos dos agrotóxicos na saúde e no ambiente. As ações de capacitação, os programas de educação continuada e de atualização para a atenção básica, urgências e a assistência hospitalar e especializada devem receber atenção no âmbito das reformas curriculares.

(8)

Ampliação do Programa de Análise de Resíduos de Agrotóxicos (PARA), com a incorporação, ao programa, de outros alimentos in natura e processados e da água.

(9)

Apoio técnico e financeiro à agroecologia como processo de reconversão tecnológica para a superação do modelo hegemônico químico-dependente.

(10)

Proteção dos mananciais de água para abastecimento humano.

(11)

Proteção da biodiversidade.

(12)

Construção de um site oficial, de acesso gratuito, com informações toxicológicas, que poderia ser tecnicamente sustentado por uma rede de universidades, incluindo a Universidade Aberta do SUS (UNA-SUS), além da Rede Nacional de Centros de Informação e Assistência Toxicológica (Renaciat), que disponibilize informações sobre efeitos tóxicos agudos e crônicos dos agrotóxicos. 